Portland State University

PDXScholar

6-27-1990

\title{
Cross-Cultural Differences in Written Discourse Patterns : A Study of Acceptability of Japanese Expository Compositions in American Universities
}

Hiroko Kitano

Portland State University

Follow this and additional works at: https://pdxscholar.library.pdx.edu/open_access_etds

Part of the Applied Linguistics Commons, Japanese Studies Commons, and the Rhetoric Commons Let us know how access to this document benefits you.

\section{Recommended Citation}

Kitano, Hiroko, "Cross-Cultural Differences in Written Discourse Patterns : A Study of Acceptability of Japanese Expository Compositions in American Universities" (1990). Dissertations and Theses. Paper 4084.

https://doi.org/10.15760/etd.5968

This Thesis is brought to you for free and open access. It has been accepted for inclusion in Dissertations and Theses by an authorized administrator of PDXScholar. Please contact us if we can make this document more accessible: pdxscholar@pdx.edu. 
AN ABSTRACT OF THE THESIS OF Hiroko Kitano for the Master of Arts in TESOL presented June 27, 1990.

Title: Cross-cultural Differences in Written Discourse Patterns: A Study of Acceptability of Japanese Expository Compositions in American Universities.

APPROVED BY THE MEMBERS OF THE THESIS COMMITTEE:

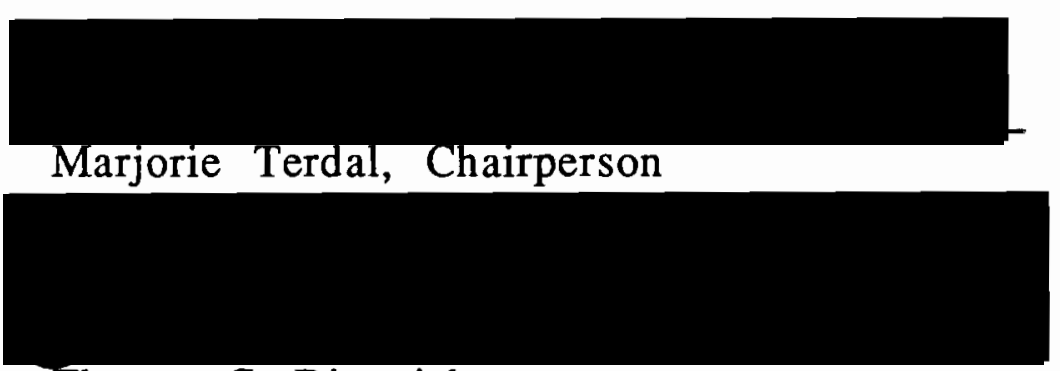

Thomas G. Dieterich

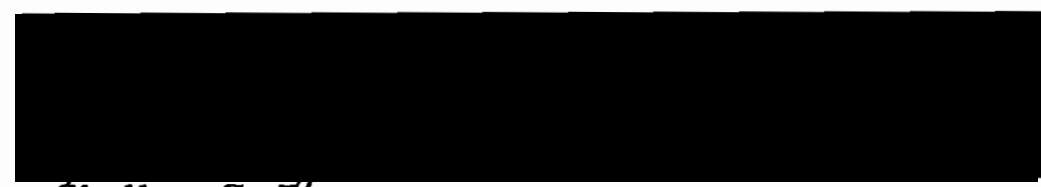

Shelley C. Beece

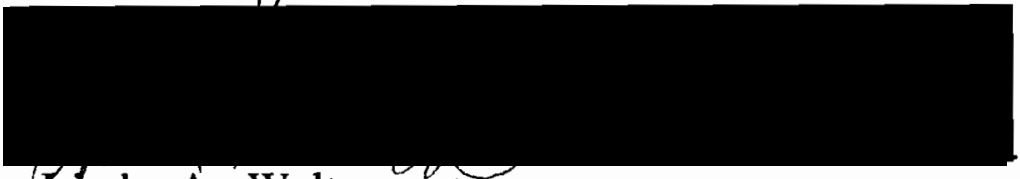

Linda A. Walton

Since Kaplan started the study of contrastive rhetoric, researchers have investigated Japanese and English compositions and have found some differences between them. However, few studies have investigated how these differences are perceived by native 
English readers when the different rhetorical patterns are transferred to English writing.

Drawing from Hinds' study, this research focuses on the following: how the Japanese style of writing is evaluated by Japanese and American readers, especially in academic situations, how Japanese rhetorical patterns are perceived by American readers, and how a change of organization affects the evaluation by American readers.

Six expository writings were selected from Japanese publications. University graduates, instructors, and students in Japan and the United States were asked to evaluate the essays in their native languages on the scale of one to five according to several categories, including unity, focus, coherence, and holistic evaluation.

Because of the differences in the curriculum at universities in the two countries, the conditions attached to the evaluations were slightly different. The American subjects evaluated the writing samples with a supposition that they were compositions for a freshman writing class, while the Japanese instructors evaluated them assuming that they were compositions written by university students. The Japanese university graduates assumed that they were written by ordinary, non-professional people.

In addition to the evaluations, American subjects responded to questionnaires on rhetorical differences for each writing sample. They were asked to determine how different they thought each writing sample was from English composition. They ranked the samples numerically and added comments on the difference. 
Three hypotheses were posed:

1. Japanese readers will evaluate Japanese expository prose written in Japanese significantly higher than American readers will evaluate the same prose translated in English.

2. There will be a positive correlation between the evaluation by American readers and the rhetorical pattern of the composition; in other words, the closer a rhetorical pattern is perceived to be like an English one, the higher the evaluation will be.

3. If a Japanese text translated into English is revised, employing a rhetorical pattern close to one employed in English writing, it will receive significantly higher evaluation by American readers than before revision.

The results were not generally significant. The Japanese readers and the American readers demonstrated considerable agreement on the evaluations of the writing samples. However, the data suggested that the two groups of readers tended to evaluate different writing samples highly, and that they appeared to have different expectations toward the properties of coherence and focus. High correlation between the evaluations and the rhetorical perceptions was observed among the American subjects, suggesting that rhetorical differences observed by American readers could be perceived negatively in English writing.

The American readers' responses to the questionnaires revealed some rhetorical differences between Japanese writing and English writing. Many of them pointed out poor transition and a lack of coherence. However, the Japanese readers may consider these 
same properties to be concise in their implications, and valued them highly. 
CROSS-CULTURAL DIFFERENCES IN WRITTEN DISCOURSE PATTERNS:

A STUDY OF ACCEPTABILITY OF JAPANESE EXPOSITORY COMPOSITIONS IN AMERICAN UNIVERSITIES

by

HIROKO KITANO

A thesis submitted in partial fulfillment of the requirements for the degree of

MASTER OF ARTS

in

TESOL

Portland State University

1990 
TO THE OFFICE OF GRADUATE STUDIES:

The members of the Committee approve the thesis of Hiroko Kitano presented June 27, 1990.

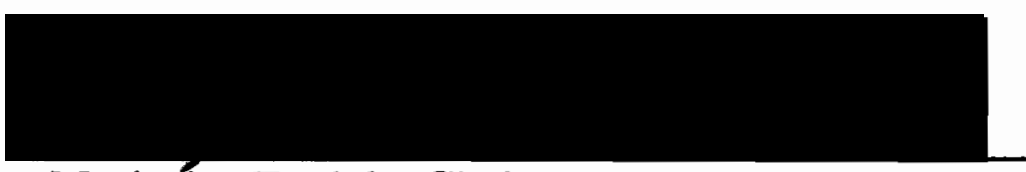

Marjorie Terdal, Chairperson

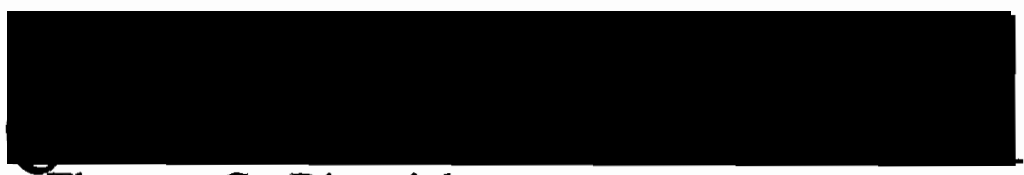

Thomas G. Dieterich

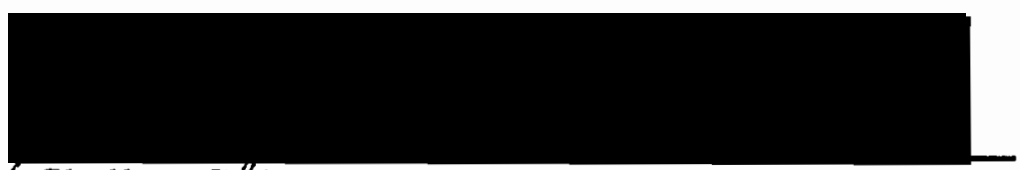

Shelley $\mathrm{C} /$ Reece

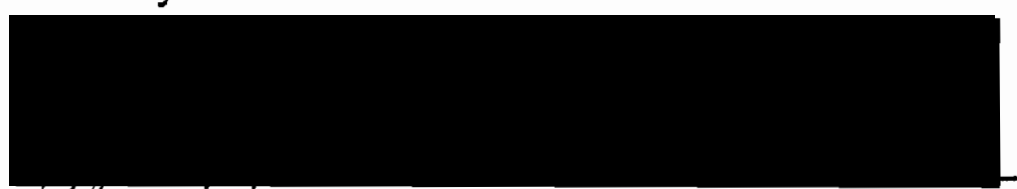

Kinda A. Walton

\section{APPROVED:}

James R. Nattinger, Chair, Department of Applied Linguistics

C. William Savery, Interim Vice Pyfovost for Graduate

Studies and Research 
To Ami and

to my late tea ceremony teacher, Mrs. Yasunaga 


\section{ACKNOWLEDGEMENTS}

Writing a thesis was a long process, which required me to develop both mentally and academically. Thanks to the help of many people in Japan and in the United States, I could complete the study and have a fruitful life in Portland.

I would like to express my deep appreciation to my advisor, Dr. Terdal, for her constant encouragement and insightful and thorough comments on the study. Her high academic standards always inspired me and led me all through the program at Portland State University. Without her, I could not have finished this study.

I am particularly grateful to Dr. Dietrich and Dr. Reece for their valuable suggestions and help in planning and conducting research. Dr. Walton also provided very useful comments to polish the study.

I would like to thank Gayl Robinson and Suzanne Raschke.

Discussions with them were very helpful for clarifying my ideas. I also learned much about English writing from both these experienced writers.

My special thanks go to many people who helped and cooperated with me on my research in Japan and in the United States. I deeply appreciate the enormous help of Professor Okamitsu, Mr. Kamimura, Mrs. Nakayama, Mrs Utsunomiya, and Mrs. Nakata during the data gathering in Japan. I would like to thank professors 
and students in the Applied Linguistics Department and the Department of English at Portland State University.

Finally I would like to thank my parents, my sister, and my brother, who have always been very supportive all through my course work. 


\section{TABLE OF CONTENTS}

PAGE

ACKNOWLEDGEMENTS............................................................................................iii

LIST OF TABLES.....................................................................................................viii

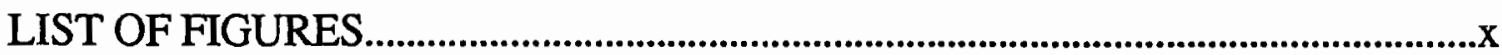

\section{CHAPTER}

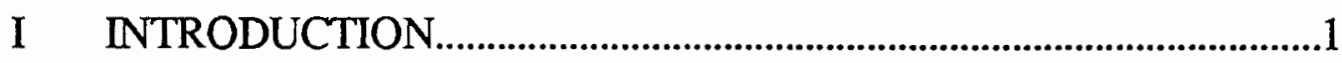

The Background of the Study..............................................1

Statement of Research Questions.......................................3

I I REVIEW OF THE LITERATURE.....................................................

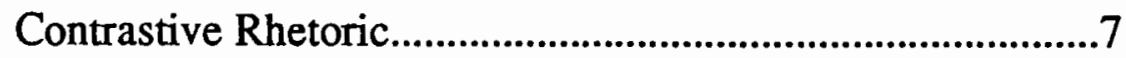

Contrastive Analysis

Kaplan's Study of Contrastive Rhetoric

Study of Contrastive Rhetoric:

English and Japanese..............................................16

Burtoff's Study

Kobayashi's Study

Oi's Study

Rhetorical Patterns: English and Japanese...................21

English Written Discourse

Traditional Approach

Modern Approach

Japanese Written Discourse

Organization of Japanese Essays

Characteristics of Japanese Discourse 
PAGE

Summary .35

\section{CHAPTER}

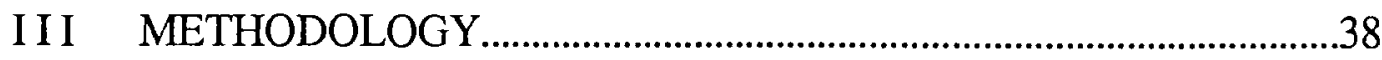

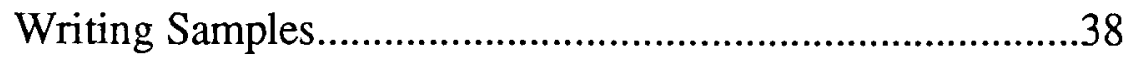

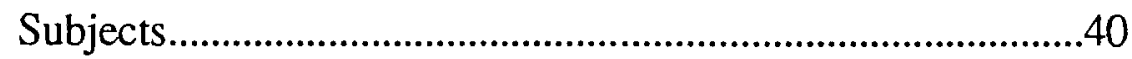

Method of Data Analysis.......................................................

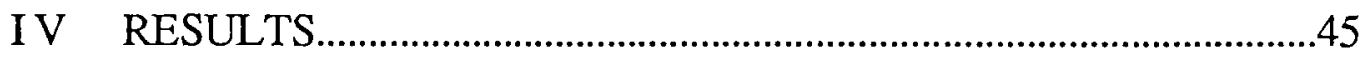

Results of Analysis across the Writing Samples......45

Instructors

University Students and Graduates

Correlation between Evaluation and Rhetorical Differences

Results of Analysis within Each Writing Sample.....65

Sample A

Sample B

Sample C

Sample D

Sample E

Sample F

Sample E and its Revision, Sample E2

$\mathrm{V}$ DISCUSSION AND CONCLUSION.................................................94

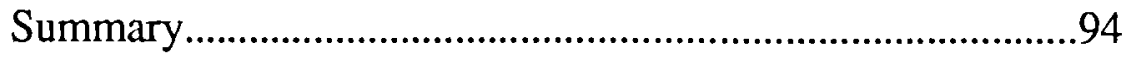

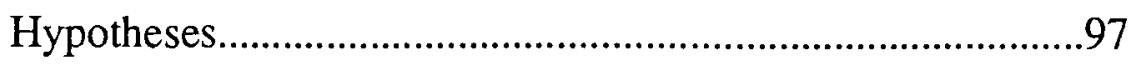

Hypothesis I

Hypothesis II

Hypothesis III

Questionnaires

Pedagogical Implications 
PAGE

Limitations of the Study and Recommendations for Further Study............................................107

REFERENCES

\section{APPENDICES}

A THE WRITING SAMPLES AND THE EVALUATION SHEET IN JAPANESE.

B THE WRITING SAMPLES AND THE EVALUATION SHEET IN ENGLISH.

C THE WRITING SAMPLES AND THE RESULTS OF THE PILOT STUDTY 


\section{LIST OF TABLES}

TABLE

PAGE

I Instructors' Means and S.D.'s: Total Score..........................46

I I Results of Instructors' Evaluations: Total Score.................48

I I I Instructors' Means and S.D.'s: Holistic Evaluation..............49

IV Results of Instructors' Evaluations: Holistic Evaluation....50

V Results of Instructors' Evaluations: Unity..........................52

VI Results of Instructors' Evaluations: Focus..........................53

VII Results of Instructors' Evaluations: Coherence...................54

VIII Students' Means and S.D.'s: Total Score................................55

IX Results of Students' Evaluations: Total Score.......................56

X Students' Means and S.D.'s: Holistic Evaluation...................57

XI Results of Students' Evaluations: Holistic Evaluation.........58

XII Results of Students' Evaluations: Unity..............................59

XIII Results of Students' Evaluations: Focus................................60

XIV Results of Students' Evaluations: Coherence......................61

XV Results of Students' Evaluations with

Sample E: Total Score.

XVI Results of Students' Evaluations with Sample E:

Holistic Evaluation.

XVII Correlation between Evaluations and

Rhetorical Differences: American Instructors..........64

XVIII Correlation between Evaluations and

Rhetorical Differences: American Students 
XIX Instructors: Sample A Comparison of Evaluations...............67

XX Students: Sample A Comparison of Evaluations.....................68

XXI Instructors: Sample B Comparison of Evaluations................73

XXII Students: Sample B Comparison of Evaluations.....................74

XXIII Instructors: Sample C Comparison of Evaluations................78

XXIV Students: Sample C Comparison of Evaluations.....................79

XXV Students: Sample D Comparison of Evaluations.....................82

XXVI Students: Sample E Comparison of Evaluations......................85

XXVII Students: Sample F Comparison of Evaluations.....................88

XXVIII American Students: Sample E and Sample E2........................92 


\section{LIST OF FIGURES}

FIGURE

PAGE

1. Robert Kaplan: Cultural Differences in

Paragraph Structures...........................................................11

2. Instructors' Mean Total Scores.......................................................47

3. The Mean Scores of Instructors' Holistic Evaluation...............49

4. The Mean Scores of Instructors' Unity...........................................51

5. The Mean Scores of Instructors' Focus.........................................52

6. The Mean Scores of Instructors' Coherence................................53

7. Students' Mean Total Scores.............................................................55

8. The Mean Scores of Students' Holistic Evaluation.....................57

9. The Mean Scores of Students' Unity...............................................59

10. The Mean Scores of Students' Focus...............................................60

11. The Mean Scores of Students' Coherence...................................61 


\section{CHAPTER I}

\section{INTRODUCTION}

\section{THE BACKGROUND OF THE STUDY}

During the past decade, the focus of composition teaching in English as a Second Language (ESL) has shifted from the written product to the process of writing. Studies of the composing process of ESL students reveal that ESL students use strategies very similar to those used by native speakers (Zamel, 1982, 1983): writing in both the native language (L1) and the second language (L2) is not linear but is "recursive, a 'cyclical process during which writers move back and forth on a continuum discovering, analyzing, and synthesizing ideas'" (Raimes, 1985, p. 229).

The similarity in writing strategies does not, however, lead to a similarity in written products. The English compositions written by ESL students, particularly by Japanese speakers, apparently differ greatly from those of native speakers. Linguistic difficulties may account for some of the difference. Japanese speakers have a limited vocabulary and a limited understanding of grammar, syntax, and stylistic choices when they write in English. In addition to linguistic factors, Spack (1988) mentions "the social and cultural factors that influence composing," which also exist in native speakers' compositions. She says: 
Even for ESL students who are highly literate in their native language, a similar gap exists: The students' lack of L2 linguistic and cultural knowledge can stand in the way of academic success (p. 30).

However, the linguistic difficulty and the social and cultural factors are not sufficient to explain the distance between the native English speakers' composition and Japanese speakers' composition in English. It is quite common for Japanese students who have an adequate command of English grammar and syntax to receive instructors' comments on their composition such as: "The material is all here, but it seems somehow out of focus," or "Lacks organization," or "Lacks cohesion" (Kaplan, 1966, p. 401). These students are often surprised at such comments and cannot perceive what is wrong with their writing. This divergence of views may come from the difference in the rhetorical patterns between English and Japanese. Japanese students may have developed their ideas by means of Japanese logic and composed them according to Japanese organizational patterns.

Purves (1986) says, "There exists within each culture or society at least one, if not several, 'rhetorical communities,"' fields with certain norms, expectations, and conventions with respect to writing (p. 39). The members of the same rhetorical community learn, follow, and expect certain rhetorical rules and forms. The violation of these rules and forms sometimes results in mere awkwardness but sometimes causes serious misunderstanding. The rules are likely to differ across cultures and disciplines. Just as Japanese culture is 
different from Western cultures, it is very likely that the Japanese language employs different rhetorical patterns than English.

\section{STATEMENT OF RESEARCH QUESTIONS}

In Japan, due to the severe competition in entrance examinations for college, English teaching at high school emphasizes grammar and translation. Fallows (1987), for example, claims:

English is taught not as a language at all, in the sense that students might actually speak it, but as a corpus of abstract facts and symbols that students must memorize to prove they are serious about school -- the way theology students learn Greek (p. 19).

One high school English teacher in Japan justified the current method by commenting that it is not only effective in preparing for the entrance examination but also convenient for teaching a class with a large number of students.

Consequently, the emphasis in English composition teaching is also placed on translation in Japan. Students learn to translate sentences, paragraphs, and the whole text from Japanese into English. The focus is mainly on grammatical correctness, and very little instruction is given on English discourse patterns. Most students, therefore, consider English composition as nothing more than translation. They believe that if they acquire a good command of English grammar and vocabulary, they can compose in English just as they do in Japanese. Therefore, it is quite possible that Japanese 
students transfer Japanese rhetorical patterns when they write in English.

Reading instruction compounds this tendency. Usually students are asked to translate, sentence by sentence, an English text that is often far above their proficiency. They sometimes have to translate syntactically and semantically very difficult texts, or "archaic constructions" (Rholen, 1983, p. 100), with the help of dictionaries. Through such instruction, students can hardly focus on the level larger than the sentence, and it is difficult for them to recognize the differences between rhetorical patterns in English and in Japanese. An abundance of professionally translated literature from English may make it more difficult for students to realize that there exist rhetorical differences between the two languages, since the professionally translated literature is accepted as much as Japanese literature is in Japan. Students do not realize that the other way is not always true. Japanese rhetorical patterns may be perceived negatively by speakers of other languages.

Thus, when teaching English composition to native Japanese speakers is the issue, it becomes important to examine the rhetorical differences between English and Japanese and the perception of Japanese rhetorical patterns by native speakers of English. Such studies will provide useful suggestions for teaching English composition to native Japanese speakers. Several studies (Burtoff, 1983; Kobayashi, 1984; Oi, 1984) have been conducted to examine the similarities and differences between English and Japanese rhetorical patterns and the rhetorical patterns used by Japanese 
native speakers in English composition. Each of these studies has found differences in the rhetorical patterns employed by native English speakers and Japanese speakers. However, few studies have explored how Japanese rhetorical patterns are perceived by native English speakers when they read an essay written in English but along Japanese rhetorical patterns. Are Japanese rhetorical patterns acceptable in the United States when they are transferred into English writing?

This research focuses on the acceptability of Japanese composition, especially expository writing, in American universities. The writing experiences of the present researcher both in a Japanese university and an American university lead to the following hypotheses:

1). Japanese readers will evaluate Japanese expository prose written in Japanese significantly higher than American readers will evaluate the same prose translated into English.

2). There will be a positive correlation between the evaluation by American readers and the rhetorical pattern of the composition; in other words, the closer a rhetorical pattern is perceived to be like an English one, the higher the evaluation will be.

3). If a Japanese text translated into English is revised employing a rhetorical pattern close to one employed 
in English writing, it will receive significantly higher evaluation by American readers than before revision.

Although this research is concerned with text reading and the readers' response, this kind of research may have an implication for writing instruction. Many researchers consider that reading and writing are the complementary processes in textual communication. Carrell (1986), for example, maintains:

Within the general framework of cognitive science, and from the perspective of text as textual communication, findings from the independent investigation of reading and writing -- that is, text comprehension and text production -- should not only complement and support each other, but, it is hoped, should lead to even more powerful theories of text and textual communication (p. 55).

Therefore, this researcher hopes that the following discussion will be a step to more effective English composition teaching to native Japanese speakers. 


\section{CHAPTER II}

\section{REVIEW OF THE LITERATURE}

The discipline that examines rhetorical differences across languages and cultures is called contrastive rhetoric. The study of contrastive rhetoric was started by Kaplan, using principles of contrastive analysis. In this chapter, first, the literature about contrastive rhetoric including contrastive analysis is reviewed, and then, three studies of contrastive rhetoric between English and Japanese are introduced. Finally, literature is reviewed concerning English rhetoric and Japanese rhetoric.

\section{CONTRASTIVE RHETORIC}

\section{Contrastive Analysis}

The relationship between second language learners' native languages and their target language learning process has been one of the main interests among linguists and language teachers, who have long noticed the influence of learners' first language (L1) on their second language (L2) production. Language teachers can often tell L2 learners' native languages by their L2 "accents." They also recognize the commonality in the errors made by the $L 2$ learners of the same native language. Such evidence suggests that L2 learners transfer their L1 system into the L2 system in their learning process. 
L1 transfer is observed not only in pronunciation but also in the choice of vocabulary and in the sentence grammar and syntax.

The comparative study across languages conducted by contrastive analysis provides a method to investigate the questions concerning L1 influence on L2 acquisition. Theoretically and methodologically based on Structuralism and Behaviorism, contrastive analysis diagnoses two or more languages and describes similarities and differences among them. The hypothesis it claims is that the primary difficulty in second language acquisition is caused by the interference of the $\mathrm{L} 1$ system with the $\mathrm{L} 2$ system and that a systematic and scientific analysis of the two languages in question will result in a contrastive description between them that will be helpful for linguists to predict the difficulties L2 learners encounter (Brown, 1987, p. 153).

Wardhaugh (1970) discusses two versions of the Contrastive Analysis Hypothesis: the strong version and the weak version. The strong version of contrastive analysis claims the predictive application to L2 teaching, while the weak version postulates the explanatory use of the evidence provided by linguistic interference. Wardhaugh argues that although the strong version is questionable in its validity, the weak version is useful and will continue to be so.

L2 acquisition is a complex process which involves a number of variables both internal and external to the learner. Therefore, contrastive analysis itself is far from predicting a variety of difficulties encountered by L2 learners. However, it effectively explains some of the difficulties in the L2 acquisition process. Such 
explanatory description will be a useful aid not only for L2 teachers but also for L2 learners who are bewildered by their own errors.

\section{Kaplan's Study of Contrastive Rhetoric}

While contrastive analysis primarily conducts descriptive study of elements at the sentence level (i.e. phoneme, sentence grammar, syntax, etc.) across languages, contrastive rhetoric examines the rhetorical level of the written texts (i.e. organization and organizational properties such as coherence of both paragraphs and the whole text). By building on contrastive analysis, Kaplan, who recognized advanced L2 learners' difficulty in academic writing, started the study called contrastive rhetoric in the mid-1960's (Kaplan, 1988). He considered that rhetoric varied from culture to culture, and negative transfer of culturally specific rhetoric to L2 writing was the main cause of the difficulty experienced by advanced L2 learners.

In 1966, in his innovative study, "Cultural Thought Patterns in Inter-Cultural Education," Kaplan articulated for the first time in the field of English as a Second Language (ESL) the notion of cultural influence on the logical organization of composition. He examined six hundred samples of ESL students' writing from three language groups: Semitic, Oriental, and Romance, and also analyzed a Russian text in English translation. He found that among those language groups, there were variations in paragraph development which were not usually acceptable in English writing.

Kaplan describes paragraph development in English as follows: 
The thought patterns which speakers and readers of English appear to expect as an integral part of their communication are a sequence that is dominantly linear in its development. An English expository paragraph usually begins with a topic statement, and then, by a series of subdivisions of that topic statement, each supported by example and illustrations, proceeds to develop that central idea and relate that idea to all the other ideas in the whole essay, and to employ that idea in its proper relationship with the other ideas, to prove something, or perhaps to argue something (p. 402).

According to Kaplan, in either type of English writing, the central idea flows in a linear way from the beginning to the end without digressing and the development of the paragraph is limited to its central idea. Unity and coherence are important elements of the quality of composition.

In contrast to the linear organization of English, Kaplan describes the paragraph development of the other four language groups as follows. Arabic paragraph development is based on a complex series of parallel constructions and most of the ideas are coordinately linked. The key characteristic of Oriental writing is indirection. The subject is looked at from a variety of tangential views, but never directly. The development of the paragraph is like a "widening gyre" circling around the subject. The discourse structure of Romance languages has much greater freedom to digress or to introduce "extraneous" material than that of English. Kaplan comments that the digression which is often seen in the writing of Western philosophers is typical in Romance languages. Some of the 
difficulty in Russian text relates to linguistic rather than rhetorical differences. The sentence structure of Russian is entirely different from English sentence structure. However, a great digression is recognized in a Russian paragraph. Kaplan represents these patterns of rhetorical organization, as shown in Figure 1.

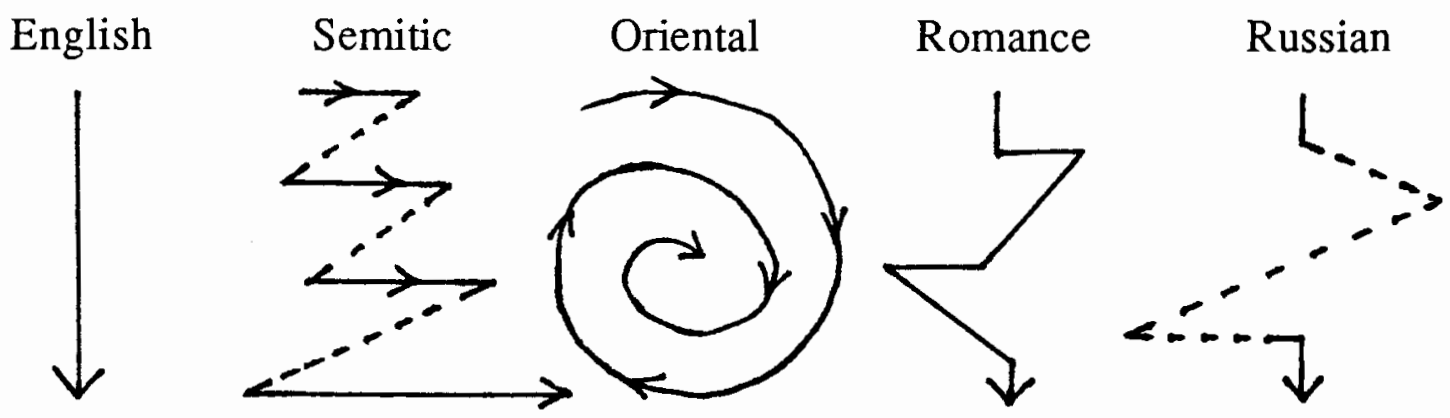

Figure 1. Robert Kapalan: Cultural Differences in Paragraph Structures.

Based on his study, Kaplan suggests that the teaching of contrastive rhetoric may help ESL students attain their aim in an English-speaking society, although their stay in the United States may be brief and English might itself be only a means to achieve their academic end in the United States.

Although Kaplan's study of contrastive rhetoric has had considerable influence on both theory and practice in writing instruction in ESL since its appearance, it has also aroused major controversy. Some challenge the validity of the methods of Kaplan's study, some are skeptical of the notion of contrastive rhetoric itself, and others dispute the focus of contrastive rhetoric research in 
general and the teaching methods developed under the influence of contrastive rhetoric.

Among those who disagree with the methods of Kaplan's study, Hinds (1983) argues that the results of Kaplan's method of data collection do not necessarily reflect the rhetoric of the foreign languages. It is quite possible that some errors by ESL students are "the result of either developmental stages of an interlanguage, or incorrect hypotheses about the target language" (p. 186). Burtoff (1983) also criticizes Kaplan's method of data collection. He maintains that Kaplan's study lacks control in three key areas: the topic of the writing assignment; the English language proficiency of the subjects; and a clear-cut method of analysis (pp. 28-29).

Another criticism concerning Kaplan's study is directed at his grouping of cultural/linguistic groups. Hinds (1983) argues that Kaplan's term "Oriental" is overgeneralized. According to him, "Chinese has a basic SVO typology, while Japanese and Korean have SOV. Chinese is topic-prominent, while Japanese and Korean share the property of being both topic- and subject-prominent" (p. 186). Therefore, Hinds maintains that each language should be studied independently.

Others argue against Kaplan's view of rhetoric in his study. Liebman-Kleine (1986) argues that Kaplan has viewed rhetoric as static instead of seeing it as a dynamic and complex process and he has too much simplified Western Rhetoric (p. 4). She maintains that research (Braddock, 1974; Meade \& Ellis, 1970) shows great variability in Western rhetoric. Contrary to the instruction of most 
writing textbooks, Braddock, for example, found that only $13 \%$ of the 673 expository paragraphs written by 25 contemporary professional writers began with a topic sentence (p. 301).

Apart from the validity of Kaplan's study, some raise questions about the primary view of contrastive rhetoric that negative L1 transfer is a major factor of difficulties in L2 learners' writing in English. Research (Bailey et. al., 1974) shows that the major source of adult L2 learners' errors is due not to interference of their L1 but "to the use of universal language processing strategies" (p. 242). Some consider this to be true on the rhetorical level as well. Mohan and Lo (1985), for example, argue that developmental factors, instead of negative transfer of $\mathrm{L} 1$, are the major cause of the difficulties Chinese students have in English composition, stating that there are no great differences between the organization of Chinese expository writing and that of English expository writing. They further assert that, because of the universality of rhetorical organization, transfer helps students rather than interferes. Liebman-Kleine (1986) also found that almost all the students in her survey were familiar with the American "Introduction/Development with Support/Conclusion" pattern (p. 10).

The last criticism comes from process approach advocates. Taking the result of research on writing in the past decade into consideration, present composition teaching tends to emphasize the process of writing, while contrastive rhetoric focuses on the product. It analyzes written products across languages and cultures and compares their rhetorical patterns. ESL writing textbooks (see 
Bander, 1978, for example) that were influenced by contrastive rhetoric focused mainly on the instruction of written form.

In spite of criticism, Kaplan's study of contrastive rhetoric continues to draw the attention of many linguists and L2 teachers. Even those who are critical of the study do not deny cultural influence on L2 writing. Although there may be a rhetorical organization that is more or less universal, it does not necessarily lead to similar products. It is quite possible that very different textures are woven within the same framework under the influence of various cultural factors.

Research conducted by the International Association for the Evaluation of Education Achievement (IEA) shows significant crosscultural differences in writing on the same topic (Purves, 1985, 1986). For the research, essays written in class on the topic "My Native Town" by secondary school students were collected from fourteen countries. They were classified along five dimensions: personal-impersonal, ornamental-plain, abstract-concrete, singlemultiple, and propositional-appositional. Some of the results are as follows: Australia -- personal, ornamental, concrete, single, and appositional; England -- medium personal, plain, concrete, multiple, and appositional; U.S.A. -- impersonal, plain, concrete, medium single, and propositional. This suggests that there are rhetorical differences even among English-speaking countries.

Concerning a dichotomy between the process and the product some researchers now propose integration of the two views both in research and in teaching. Connor (1987) claims that an integrative 
theory gives explanation of the apparent inconsistency in some process research where writing processes have been described by means of analyzing products (p. 678). Coe (1987) proposes writing instruction that "places form in the context of various processes: creative, communicative, mental, social, and learning" (p. 26). Raimes (1985) and Spack (1988) also mention the necessity of attending to form as well as process. L2 speakers have less knowledge of form, or rhetorical rules of the target language and culture, than L1 speakers. Therefore, the teaching of form becomes more important and beneficial to L2 speakers.

Recently contrastive rhetoric has given consideration to the various factors that influence the rhetorical structure of the text. Kaplan (1989) presents a new definition of contrastive rhetoric as follows:

contrastive rhetoric is the study of L1 rhetorical influences on the organization of text in an L2, on audience considerations, on goal definition; it seeks to define L1 influences on text coherence, on perceived audience awareness and on rhetorical context features (i.e., topic constraints, amount of subject matter knowledge needed to accomplish a given task, assignment constraints, writer maturity, educational demands, time available for composing, time available for feedback and revision, formal conventions of the writing task, etc.) (p. 266).

The consideration of these manifold factors offers contrastive rhetoric a more reliable and deeper description of L1 influence on L2 writing. L1 influence may account for only a part of the problems L2 
speakers have in writing. However, as contrastive rhetoric explores the field in which one of the main differences between L1 speakers' writing and L2 speakers' writing exists, knowledge of contrastive rhetoric provides important information for L2 writing instruction. It is helpful not only for L2 instructors but also for students. Matalene (1985), who taught English in China, for example, discusses the value of understanding contrastive rhetoric:

Only in retrospect and after study and discussion did I begin to understand the linguistic and rhetorical agendas that were influencing my students' writing in English. Had I known then what I have come to know now, I am sure that my classroom presence and my social interactions might well have been less obstrusive and more effective. Much of the time I was no doubt offering my students the instructional equivalent of cheese (pp. 790-791).

\section{STUDY OF CONTRASTIVE RHETORIC: ENGLISH AND JAPANESE}

This section reviews three studies on contrastive rhetoric between English and Japanese. These researchers conducted discourse analyses of expository compositions written by both native speakers of English and native speakers of Japanese, and examined similarities and differences in logical and rhetorical patterns between the language groups.

\section{Burtoff's Study}

Burtoff (1983) analyzed the logical organization of English compositions written by native Japanese speakers, native Arabic 
speakers, and native English speakers. She focused specifically on the question of whether or not logical organization is affected by the nature of the topic. In other words, if the topic is culturally loaded, are the logical organizational patterns more culture-specific; if the topic is universal, do all language groups use more similar patterns?

Burtoff's findings include several strategies culturally preferred by each language group; some of them support Kaplan's notion of cultural thought patterns.

Japanese strongly culturally-preferred strategies:

(1) ending texts and/or segments of information in a text with a generalization; these generalizations usually overlapped with a previously occurring explanation.

(2) ordering information so as to form causal chains, e.g., $A$ because $B$ as a result $C$ because $D$.

(3) using ADVERSATIVE relation in the context of a cause; i.e, they habitually introduced contrary information creating a new kind of RESPONSE predicate.

American strongly culturally-preferred strategies:

(1) the reintroduction of information which occurred earlier in the text in order to develop another aspect of it (pp. 170-171).

However, she emphasizes that none of the strategies employed by her subjects were culturally unique and that all groups had access to all the variety of logical strategies. She concludes that "although cultural background plays a certain role in the choice of some strategies, all writers regardless of cultural background may employ similar strategies, many of which are topic-dependent" (pp. 174- 
175). Based on her study, Burtoff suggests that all writers with little formal writing instruction need no special instruction linked to their cultural background and require the same type of instruction.

\section{Kobayashi's Study}

Kobayashi (1984) examined rhetorical patterns and general statements in the written texts composed by native English speakers and native Japanese speakers. Her Japanese subjects consisted of three groups: Japanese advanced ESL students in America writing in English, Japanese students majoring in English in Japan writing in English, and Japanese non-English major students in Japan writing in Japanese.

To analyze organizational patterns, Kobayashi established four pattern categories according to the place of general statement in the text: (1) general-to-specific, (2) specific-to-general, (3) a middle general statement, (4) omission of a general statement. Patterns that did not fall into either of these four categories were placed in an undetermined category. Kobayashi classified types of general statements into three categories: stating the topic (writers simply restate the topic without presenting the text information), restating the text information (an objective style in which writers present what they are writing about in a generalized fashion), and relating the text information to the writer's own experience (a style in which writers reveal their personal values, beliefs, feelings and experience in relation to the text) (p. 177). 
Kobayashi found consistent differences among groups. American students frequently used the general-to-specific pattern and restated the text information. The Japanese students writing in Japanese frequently used the specific-to-general pattern and related the text information to the writer's own experience. The two groups of Japanese students writing in English were also different from each other. The Japanese students in America used a rhetorical pattern relatively close to that used by the American students, whereas the group in Japan used a rhetorical pattern close to the pattern used in writing in Japanese. From these results, Kobayashi concludes:

a strong relationship between culture and rhetorical modes of expression exists in two aspects of American and Japanese students writing: The choice of rhetorical patterns and the use of specific kinds of general statements (p. 175).

\section{Oi's Study}

Oi (1984) conducted discourse analysis to investigate similarities and differences in rhetorical patterns of expository writing between English and Japanese. Her data were collected from three groups of students: American students writing in English, Japanese students writing in English, and Japanese students writing in Japanese. Oi analyzed the data in terms of the following: (1) cohesion devices, (2) organizational patterning, and (3) cultural rhetorical tendencies.

Oi found several differences between Japanese students' writing and American students' writing. First, concerning cohesive 
devices, although some of the differences seemed to be caused by linguistic differences, Japanese students used more conjunctions than American students and repeatedly used the same word both in Japanese and in English.

Secondly, the findings with regard to organizational patterning showed considerable cultural differences. The overall organization was more or less similar to Kobayashi's study. American students showed strong preference for the (American) general-to-specific pattern, while Japanese students writing in Japanese frequently used the specific-to-general pattern. Unlike Kobayashi's results, Oi found that Japanese students writing in English preferred the general-tospecific pattern rather than the specific-to-general pattern, although it was not so strong a tendency as with American students. Concerning argumentative patterning, American students frequently used a linear pattern, whereas Japanese students used a mixed pattern.

The analysis in terms of cultural tendencies found significant differences. American students preferred to use hyperbolic expressions, while Japanese students rarely did. American students also used the superlative frequently, which makes the statement decisive. Japanese students, on the other hand, often started sentences with "hedges" such as "I feel," "I think," and "I suppose," which make the statement indirect.

Oi maintains that the above results suggest the importance of indicating the rhetorical differences of the two languages when English composition is taught to Japanese students. 


\section{RHETORICAL PATTERNS: ENGLISH AND JAPANESE}

In this section, the rhetorical patterns of English written discourse and Japanese written discourse are reviewed. The section concerning Japanese written discourse also includes the characteristics of Japanese discourse.

\section{English Written Discourse}

The Western rhetorical tradition begins in the ancient GrecoRoman period. Although rhetoric was originally developed and refined for oration, contemporary written rhetorical theory is based primarily upon the Greco-Roman tradition. Aristotle defined rhetoric as "the art of discovering all the possible means of persuasion on any subject whatsoever" (Hughes \& Duhamel, 1962, p. 4). There was assumed confrontation between an orator and the audience, and it was the orator's role to logically persuade the audience and to make them agree with him. This historical background would have elicited the following characteristics of English rhetoric: "linear" (Kaplan, 1966), "direct and explicit" (Ishii,1982), "dichotomous" (Condon \& Yousef, 1975), and "polarized" (Okabe, 1983).

Traditional Approach. English texts of any kind consist of three parts: Beginning, Middle, and End (Hughes \& Duhamel, 1962, p. 2; Baker, 1972, p. 38). These three parts are further assigned to smaller discourse units called paragraphs. In the Beginning, writers usually state their thesis, which is a main idea that leads the text in a certain direction. In the Middle, paragraphs are usually developed 
with different patterns according to the following forms of discourse: "narration, description, details, definition, comparison or contrast, cause or effect, examples and illustration, enumeration, classification" (Lindemann, 1982, p. 141). In the End, the text is concluded in various ways.

Baker (1972) points out that the classic oratorical form "appears universally behind the structure of the essay and the scientific report" (p. 38). He itemizes the structure of the usual classical oratorical form:

1. Exordium. The introduction

2. Narratio. General description of subject and background.

3. Propositio. The thesis, the statement of what is to be demonstrated or proved.

4. Partitio. Statement of how the thesis is to be divided and handled.

5. Confirmatio (or Argumentatio, or Explicatio). The chief evidence in support of the thesis; the body, the longest part, of the oration.

6. Reprehensio. The knocking-out of the opposition.

7. Digressio. The digression.

8. Peroratio. The conclusion (p. 39).

Baker compares the classic oratorical form with the modern essay form. According to Baker, the first three, Exordium, Narratio, and Propositio, are viewed as the Beginning in modern essays;

Confirmatio and Reprehensio are the Middle, although Reprehensio is followed by Confirmatio; and Peroratio is the End in modern essays. 
Paragraphs are also viewed as important units of discourse with a certain common structure. Lindemann (1987) summarizes rules for effective paragraphs first set forth by Bain in 1866:

1. Distribution into Sentences: The consideration of the Unity of the individual Sentence leads up to the structure of the Paragraph, as composed of sentences properly parted off.

2. Explicit Reference: The bearing of each sentence of a Paragraph on the sentences preceding needs to be explicit.

3. Parallel Construction: When several consecutive sentences iterate or illustrate the same idea, they should, as far as possible, be formed alike.

4. Indication of the Theme: The opening sentence, unless obviously preparatory, is expected to indicate the scope of the paragraph.

5. Unity: Unity in a Paragraph implies a sustained purpose, and forbids digressions and irrelevant matter.

6. Consecutive Arrangement: The first thing involved in Consecutive Arrangement is, that related topics should be kept close together: in other words, Proximity has to be governed by Affinity.

7. Marking of Subordination: As in Sentence, so in the Paragraph, Principal and Subordinate Statements should have their relative importance clearly indicated (Lindemann, 1987, p. 142).

A similar set of rules is often found in many modern writing textbooks as a description of good paragraphs. Readers have a certain expectation toward a paragraph both in form and in content. Modern Approach. Contemporary rhetoricians have approached the structure of paragraphs in several different ways. Becker (1965), for example, applies the concept of the tagmeme to 
structural analysis of expository paragraphs. The tagmeme is "the class of grammatical forms that function in a particular grammatical relationship" (p. 237). He divides "the sequence of discourse into functional slots and filler classes" (p. 238). Based on his analysis, Becker maintains that TRI (topic, restriction, and illustration) and PS (problem and solution) are the two major patterns of expository paragraphs.

Christensen (1965), in his approach, generative rhetoric, claims that "the paragraph has, or may have, a structure as definable and traceable as that of the sentence and that it can be analyzed in the same way" (p. 144). The main conclusions of his paragraph analysis are:

1. The paragraph may be defined as a sequence of structurally related sentences.

2. The top sentence of the sequence is the topic sentence.

3. The topic sentence is nearly always the first sentence of the sequence.

4. Simple sequences are of two sorts -- coordinate and subordinate.

Christensen also mentions some exceptions: some paragraphs have no top, or no topic, sentence; some paragraphs have sentences at the beginning or at the end that do not belong to the sequence; some paragraphing is illogical. However, his overall description of paragraphing is similar to traditional prescriptive paragraph patterns. Stern (1976) asserts that Christensen's conclusions are hardly distinguishable from Bain's. 
Rodgers (1966) proposes a more flexible and open-ended approach, which he calls discourse-centered rhetoric. He suggests that writing is "a complex sequence of events in time" (p. 5) and that paragraphing is decided not merely for formal and logical reasons. Writers indent paragraphs for special consideration as stadia of discourse. Rodgers states his view of paragraphs as follows:

Thus the paragraph can be described very roughly as an autochthonous pattern in prose discourse, identified originally by application of logical, physical, rhythmical, tonal, formal, and other rhetorical criteria, set off from adjacent patterns by indentations, and commended thereby to the reader as a noteworthy stadium of discourse (pp. 5-6).

Some rhetoricians examine the structure of the whole text by applying new approaches. Grady (1971), for example, extends Christensen's theory to the essay level, stating that "there is a strong analogy between the structure of the expository paper and the structure of the expository paragraph" (p. 864). He argues that the relationship between the introductory paragraph and the supporting paragraphs in an essay is structurally similar to that of the topic sentence and the subsequent sentences in a paragraph.

D'Angelo (1974) also examines essays from the viewpoint of generative rhetoric. He, however, considers the whole text as "primarily a sequence of structurally related sentences" and secondarily as "a sequence of structurally related paragraphs" (p. 388). Based on his analysis, he concludes that paragraphing is determined by more than formal and logical factors (p. 394). 
Lindemann (1987) further explains D'Angelo's view (1975) as follows:

In other words, thinking is relational. When we perceive objects and events, we don't merely isolate or identify them; we relate them to other objects and events, to our own past experiences. If thought processes relate perceptions, organizing them into patterns, then it follows that paragraphs will express those relationships. Not only paragraphs, but also sentences and whole discourse (p. 146).

All the levels of the essay are related to the writer's underlying thought processes. These underlying thought processes are realized by actual written representation of all the levels of the essay. Thus, sentences and paragraphs are formed more by the writer's underlying thought than by the traditional prescriptive forms. As an application of D'Angelo's theory, Lindemann proposes the teaching of not mere paragraphs but of paragraphing to students.

In conclusion, in the long history of rhetorical pursuit, English rhetoricians have built up very rigid and prescriptive rhetorical rules. Although modern rhetoricians attempt various descriptive approaches to rhetoric, some of the patterns found by them are still not so different from those prescribed by traditional rhetoricians. Some, such as D'Angelo and Rodgers, propose more flexible approaches to composition. Research by Braddock (1974), which found the fallacy concerning the placement of topic sentences in the paragraph, would support such approaches. However, when English rhetoric is viewed crossculturally, the long-nurtured prescriptive 
rhetorical rules seem to remain the basic expectation of many English readers.

\section{Japanese Written Discourse}

Contrary to Western language development, which largely depended on oration, Japanese language has developed and become more sophisticated depending on written literature such as poetry, tales, diaries (Nakashima, 1987, p. 3). Traditional essays, whose influence is apparent in many kinds of modern Japanese writing, are called zuisou or zuihitsu. (Zui means "arbitrary", sou means "thought", and hitsu means "pen" or "writing"). Japanese writers traditionally recorded thoughts and feelings just as they came up, and the ancient readers' purpose was a vicarious experience (Tokoro, 1986 , p. 25). The readers not only enjoyed a literary work but also sought to experience its world themselves.

The nature of Japanese society and culture should also be taken into consideration to understand the characteristics of Japanese language. Okabe (1983) points out homogeneity and verticality as two key concepts for understanding the nature of Japanese society. In a homogeneous society like Japan, fewer words are required for mutual understanding, and in the vertical, or hierarchical, society, language assumes a greater role in establishing and maintaining smooth relationships and more words are spent for this purpose. People tend to avoid direct and strong assertion of their opinions.

Japanese rhetorical patterns, which have developed in the above historical and socio-cultural circumstances, are often 
characterized as follows: "indirect" (Kaplan, 1966, Ishii, 1982), "implicit" (Ishii), "aggregative" (Okabe, 1983), "point-like, dot-like, space-like reasoning" (Ishii, Okabe).

Organization of Japanese Essays. With a growing interest in Japanese language and composition, many books on these subjects have recently been published in Japan. Some of them provide valuable insights into Japanese language and its logic or rhetorical patterns from various points of view (Itasaka, 1971; Toyama, 1973, 1976; Tousu, 1987). Others provide instruction on how to write good essays (Ougiya, 1965; Hirai, 1972; Kabashima, 1980; Ogawa, 1982). Very few, however, have studied actual organizational patterns used in modern Japanese essays.

There are two traditional patterns that influence the organization of modern Japanese prose. One is called ki-sho-ten$k e t s u$, and the other jo-ha-kyu. The ki-sho-ten-ketsu pattern, which originated from the organization of ancient Chinese poetry ( $\mathrm{Han}$ poetry), is often used for the organization of modern essays (Shiraishi, 1982). This pattern is briefly explained as follows:

$\mathrm{Ki}------$-introduction to raise questions about the theme and to attract the interest of readers.

Sho-----succession and development of the theme raised in $k i$, clarifying, elaborating.

Ten----a change of a point of view to give readers a little surprise and to draw them into the story. 
Usually a subtheme that does not directly relate to the theme is discussed.

Ketsu---conclusion of the story and the answer to the questions raised.

Hinds (1982b) points out that two aspects in this pattern may cause problems to English readers: ten and ketsu. A change of a point of view in ten appears to be a digression to English readers, and the conclusion in ketsu, which is not necessarily decisive, is different from what English readers generally expect. Kobayashi (1984), in her study, attributed Japanese students' frequent use of the specific-to-general pattern to the influence of the $k i$-sho-tenketsu pattern.

The other pattern, jo-ha-kyu, originated from the structure of Japanese traditional Noh drama, and these terms jo-ha-kyu have come generally to indicate the beginning, the middle, and the end of artistic works within which the passing of time occurs.

Jo------introduction; gradual and calm opening of the story.

Ha-----development; happening of stormy events, climax of the story.

Kyu--.--end; rapid finale.

Hinds (1982b) maintains that this pattern, with a fairly linear structure, is similar to normal English rhetorical style. Ougiya 
(1965), referring to the structure of $j o-h a-k y u$, argues that most Japanese modern essays consist of three parts.

In addition to these traditional patterns, Western rhetoric has had considerable influence on modern Japanese writing. Students learn the Western "introduction-body-conclusion" pattern along with the ki-sho-ten-ketsu pattern at school, and many composition books introduce both Western and Japanese traditional patterns for effective essay organization. Kabashima (1980) maintains that the traditional Japanese rhetorical patterns are not effective for logical persuasive writing, and he suggests several organizational patterns that are largely based on Western rhetorical patterns such as "problem-solving." Tokoro (1986), however, is cautious toward the simplistic application of Western rhetorical patterns without considering the question of Japanese logic. He argues that the introductory part of the Japanese essay is not the introduction of Western "introduction-body-conclusion" but the jo of traditional jo$h a-k y u$, in which the story opens gradually and calmly.

Although several patterns can be found for the organization of Japanese prose, the notion of paragraphs seems to be ambiguous. Toyama (1976) states his impression about paragraphs:

When we write composition, we do not pay so much attention to paragraphs. Sometimes we indent a new paragraph, for the previous paragraph seems too long. We hardly have any sense of paragraphing (pp. 20-21). 
Some researchers conducted studies to examine the nature of paragraphing in Japanese written discourse. Makino (1978) prepared unindented texts and asked both Japanese and American subjects to choose acceptable and unacceptable paragraphings from among suggested paragraphings. He suggests that:

the most acceptable paragraphing for the subjects are those which keep intact the thematic and grammatical cohesion of each suggested fragment of the discourse (p. 286).

From his findings, he concludes that the paragraph is a "grammaticosemantic" unit both in Japanese and in English.

Kobayashi (1984) presents alternative explanations of Japanese paragraphing. She refers to the work of Hinds and Sakuma. Hinds prepared unindented text in Japanese and in its English translation and asked both native Japanese speakers and English speakers to divide the text into paragraphs. He found significant differences in paragraphing between the speakers of the two languages. Kobayashi states, "Hinds' study suggests that a Japanese paragraph is a semantic unit more than a grammatical one" (p. 35). The same was found in Sakuma's study. Her Japanese subjects showed considerable discrepancy in paragraph segmentation. As reasons for determining paragraphs, $52 \%$ of them gave content-related reasons like "change of content", while $20 \%$ of them suggested reasons concerned with "grammatical forms". "Thus, a Japanese paragraph, Sakuma states, is 
basically a unit of content, but it is marked by grammatical forms" (Kobayashi, 1984, p. 36).

\section{Characteristics of Japanese Discourse. If applied to English} discourse, some characteristics of Japanese discourse may be perceived very differently and elicit negative evaluation by English readers. Condon and Yousef (1975) contrast Anglo-American speech organization and Japanese speech organization. According to them, in Anglo-American speech organization, the conclusion or generalization comes first, followed by supporting evidence, while in Japanese speech organization, either abstractions (generalizations) or specific points but not both are mentioned. Condon and Yousef state that in Japan, it is the audience's job "to make the connection, just as the reader of haiku (a Japanese 17 syllable poem) is to sense the full literary experience from the brief image of the poem" (p. 242).

Hinds (1987) proposes a typology based on these characteristics of the English and Japanese languages. He maintains that in English, the speaker or the writer is primarily responsible for effective communication ("a writer responsible language"), whereas in Japanese, it is the listener or the reader who assumes primary responsibility for understanding what is said ("a reader responsible language") (p. 143). This suggests that Japanese discourse depends on the assumed large background knowledge shared between the writer and the readers.

Japanese scholars also indicate this characteristic of Japanese discourse. Okabe (1983), characterizing the Japanese thinking pattern as pointlike, dotlike, and spacelike, argues as follows: 
The listener is supposed to supply what is left unsaid. In the homogeneous society of Japan much commonality is taken for granted, so that the Japanese tend to value those loose modes of communication that leave much room for various interpretations (p. 29).

Ishii (1982) refers to this feature of Japanese discourse in terms of "Stepping Stones", and analyzes Japanese discourse as follows:

Using the Japanese "Stepping Stone" approach, the speaker or writer organizes his or her ideas and sends them implicitly and indirectly, as if arranging stepping stones from [one point to the next point]. Sometimes the arrangement itself is not clear and the listener or reader must infer or surmise the intended meaning. Haiku poems serve as good examples (p. 100).

The "loose modes of communication" or the "stepping stone" pattern of Japanese discourse may seem to be incoherent to English speakers and become problematic in communication.

Waka, another type of Japanese poetry, is discussed by Nakashima (1987). He describes the concise and implicit structure of waka (a Japanese 31 syllable poem, which is older than haiku) by comparing it with an English translation. Following is a waka poem and its word by word English translation.

Ama no hara furisake mireba Kasuga naru

heaven of field looking up

Kasuga in

Mikasa no yama ni

ideshi tsuki kamo

Mikasa-mountain above rose moon (particle with the meaning of admiration) 
According to Nakashima, Ama no hara furisake mireba can be translated as "looking up a vast expanse of heaven." The subject of the verb "looking" is "I." The next part, Kasuga naru Mikasa no yamani ideshi tsuki, means "the moon which used to rise above Mikasa-yama in Kasuga." Therefore, Japanese readers have to supply the information of "I see the moon" and "It reminds me of ..." between the two parts from the context or their background knowledge. Nakashima translates the complete poem as follows:

Looking up to the vast expanse of the heaven, I see the moon. It reminds me of that old moon which used to rise above Mikasa-yama in Kasuga (pp. 8-9).

Although haiku and waka represent the ultimate concision and implicitness, Nakashima maintains that this implicit tendency is also seen in prose.

Kindaichi (1988) points out that the Japanese tend to use fewer conjunctions. This provides linguistic support for the "stepping stone" pattern of Japanese discourse. He argues that it is not only because particles and inflected forms of verbs can replace conjunctions but because the Japanese refrain from indicating the clear relationship between sentences for the preference of suggestiveness.

Kindaichi's argument seems to contradict the findings of Oi's study in which Japanese students used more conjunctions than American students when they wrote both in Japanese and in English. However, this author considers that the use of conjunctions may 
closely relate to the maturity of the writers. The more mature writers are, the fewer conjunctions they tend to use. Shimokoube (1986) conducted research to analyze parts of speech in twelve short stories written by Yasunari Kawabata. The results show that one of them contained no conjunctions and in most of the stories conjunctions constitute fewer than one percent of all the words in the texts.

In conclusion, Japanese rhetoric lacks clearly determined patterns in comparison with English rhetoric. Although the traditional patterns, $k i$-sho-ten-ketsu and $j o-h a-k y u$, present fairly similar structures to English essay organization, they provide only loose overall structures. Japanese rhetoric also lacks solid paragraph structure. Paragraphs seem to be more semantic than grammatical units in Japanese writing. The influence of socio-cultural factors on the language has created considerable differences from English discourse. Implicitness, especially, which is highly valued in Japanese writing, may become a problem when Japanese speakers write in English, for it could cause incoherence in English writing.

\section{SUMMARY}

Contrastive rhetoric examines rhetorical similarities and differences across languages and cultures. Kaplan, who noticed cultural influence on English as a Second Language (ESL) students' compositions, articulated the notion of contrastive rhetoric for the first time in the ESL field. His pioneering study has drawn both 
attention and criticism, and researchers have argued over the validity of his study. Following and challenging Kaplan's study, many studies have been conducted to examine and compare rhetorical patterns in various languages. Some researchers studied contrastive rhetoric between English and Japanese, and found considerable differences. The review of literature on English rhetoric and Japanese rhetoric also indicates some differences. Beginning in Greco-Roman society, English rhetoric has built up solid and prescriptive structures for essays and paragraphs, while Japanese rhetoric provides only loose structures and many features that reflect socio-cultural values in the Japanese society. Cultural influence is significant in both Japanese discourse patterns and English discourse patterns.

Writing is a complex process that involves various factors. When different cultures and different languages are involved, writing in a second language is more complicated. The study of contrastive rhetoric could provide some explanation for the differences between native English speakers' writing and non-native speakers' writing in English. ESL teachers could draw useful suggestions for teaching writing from the research on contrastive rhetoric. In this research, the present researcher focuses on the evaluation and the perception of Japanese writing in an American university, and examines how some Japanese rhetorical patterns are evaluated and perceived in American academic situations. The present researcher hopes such a study will provide some useful 
suggestions for teaching English composition to Japanese speakers, especially, in Japan. 


\section{CHAPER III}

\section{METHODOLOGY}

This study was a survey conducted both in Japan and in the United States based on Hinds' research. This chapter describes the method used to gather data, including the samples used for the study, the subjects in the study, and the data analysis.

\section{WRITING SAMPLES}

The framework for this research was based on Hinds' research (1982a) investigating whether the Japanese style of writing is more highly valued in Japanese than in English. He selected several articles from Tensei Jingo (Vox Populi, Vox Dei), and asked both Japanese and English readers to evaluate them. Tensei Jingo is the title for the newspaper editorial of a Japanese newspaper, and English translations of those editorials, most of which are 400 to 450 words long, are published seasonally as a book under the same title in Japan. As the translation is carried out sentence by sentence, the English translation still maintains the Japanese organization.

The participants in Hinds' study evaluated the articles according to three categories on a scale of one to five: one being poor and five being excellent. The results were that Japanese readers 
consistently evaluated the articles from 1.3 to 2.2 points higher than English readers did.

Like Hinds' study, this research focused on how the Japanese style of writing was evaluated by Japanese readers and American readers, especially in academic situations. In addition to evaluation, this research, however, examined how Japanese rhetorical patterns were perceived by American readers and how a change of organization affected the evaluation by American readers.

For this study, the present researcher, avoiding culturally loaded topics, selected six expository writing samples. (See Appendix A for writing samples.) Sample A, which seemed to have rhetorical patterns close to American ones, was taken from a newspaper column; Sample B, which was listed by Shiraishi (1982) as an example of a Japanese traditional rhetorical pattern (ki-sho-tenketsu), was taken from an essay book; Samples C, D, E, and F were selected from Tensei Jingo without any noticeable discrimination. Sentence by sentence English translation was prepared for each of the samples; Samples A and B were translated by the present researcher and checked by a bilingual speaker of Japanese and English; the translations of Samples C, D, E, and F were taken from Tensei Jingo (1988). The English translation of Sample E was revised by consulting the bilingual speaker (Sample E2) so that the organization would be closer to an English organizational pattern. (See Appendix B for writing samples in English translation.) Each essay was evaluated on four criteria: unity, focus, coherence, and holistic evaluation. The evaluative categories were 
primarily based on Hinds' (1982a) categories, with holistic evaluation was added as a fourth category. (See Appendix B for an English evaluation sheet.) For the research in Japan, the terms of these categories were translated into Japanese, and overall impression, and expressive remarks (choice of sentence structure and vocabulary), which are often referred to in evaluation of compositions in Japan, were added as categories. (See Appendix A for a Japanese evaluation sheet). However, as the focus of this study is mainly on organizational patterns, they were deleted in the research in the United States. Although detailed definitions were included in the English evaluation, they were deleted in the Japanese translations. As the review of the literature on Japanese written discourse shows, Japanese readers are likely to have different notions from English readers on the evaluative categories, particularly coherence. The definitions of the categories from the viewpoint of English writing could affect Japanese readers' original evaluations.

\section{SUBJECTS}

This research was conducted in the United States and in Japan. Both American and Japanese subjects were asked to evaluate the writing samples according to the attached evaluation sheets in their own languages. The subjects in each country were divided into two groups: university instructors and university students or their equivalents. 
In the United States, university instructors consisted of professors in Applied Linguistics, professors in English, instructors in ESL, and teaching assistants for the required freshman composition course at the university. All were from the same university. Forty instructors were given Samples A, B, and C, and asked to evaluate them as if they were written for the freshman composition class, according to four categories: coherence, unity, focus, and holistic evaluation. Twenty responses were received.

Ninety-four students in the same American university were also asked to evaluate all six writing samples, with the supposition that they were essays written for the freshman composition class. These subjects consisted of students in the TESL certificate program, the M.A. TESOL program, and the English M.A. and B.A. programs at the university. Half of the subjects were given the sets of writing samples including Sample E; the other half were given the sets including Sample E2. Forty subjects (twenty for each set) responded for the research.

Along with evaluating the writing samples, all the American subjects were asked to fill out a questionnaire about each writing sample containing two questions:

1) How different do you think this composition is from an English composition?

2) In what ways is this composition different from an English composition? 
An ordinal scale of one to five was provided for the first question: one being "very different" and five being "very similar," The second question was open-ended and was divided into two parts:

(1) intraparagraph level
(2) interparagraph level

In Japan, thirty instructors in one university, that is, in humanities, in liberal arts, and in education, were asked to evaluate the same samples that were evaluated by American university instructors according to six categories: unity, focus, coherence, expressive remarks, overall impression, and holistic evaluation. As no writing classes in the Japanese language are offered in the university in which this research was conducted, the Japanese instructors were asked to evaluate the samples, assuming that they were written by Japanese college students. Twenty-six responses were received.

To make the student subjects in Japan equivalent to American university students, university graduates were selected instead of university students in Japan. In Japan, almost all the university students are from 18 to 22 years old, while the American subjects majoring in the MA: TESOL program or the TESL certificate program are older, ranging in age from 21 to middle-age. The professions of the Japanese university graduates vary; some are high school teachers, some are company workers, and some are housewives. They were asked to evaluate six writing samples (Samples A, B, C, D, 
$\mathrm{E}$, and F) assuming that those samples were essays written by ordinary, non-professional people,for it was unlikely that these subjects were familiar with university students' compositions. Despite the different assumptions between the subject groups in Japan, the results of the research show that there was very little difference in the evaluation between the Japanese university instructors and the Japanese university graduates. Seventy-five student subjects completed the evaluation of the six essays.

\section{METHOD OF DATA ANALYSIS}

Because more Japanese subjects responded than American subjects, only some of those Japanese responses could be used. To make the number of responses from the two countries equal for the analysis, twenty samples were selected randomly from Japanese university instructors and forty from Japanese university graduates. Ordinal data ranging from one to five were collected from the evaluations of the writing samples by American subjects and Japanese subjects. American subjects also provided ordinal data ranging from one to five for the perception of rhetorical differences for each sample.

The analysis of the data was divided into two sections. In the first section, the scores between the subject groups were analyzed across all the writing samples, and the correlation between the perception of rhetorical differences and the evaluation of American subjects was analyzed within each writing sample. In the second 
section, the evaluation by the two subject groups was compared within each individual writing sample, and the results of the questionnaires were discussed. In each section, the evaluations by university instructors and the evaluations by university students or university graduates were analyzed separately, since university instructors evaluated only Samples A, B, and C; while university students or their equivalents evaluated all six samples.

In the first section, the data were analyzed using a two factor mixed design of ANOVA; the correlation between the American subjects' evaluations and their perception of rhetorical differences were analyzed by Pearson's Product-moment correlation. The independent variable between subjects was Nation (Japan and the U.S.A.); the independent variable within subjects was Writing Sample (Sample A, B, C, D, E, and F). The data were initially compared by the t-test and the Mann-Whitney $U$ test for ordinal data. The results were very similar, suggesting that the data approximated a normal distribution. The perception of rhetorical differences was also analyzed together with the evaluation of American subjects across the writing samples, using a two factor mixed design of ANOVA.

In the second section of the analysis, the evaluations of American subjects and Japanese subjects were compared within each writing sample, using the two-tailed $t$-test. The independent variable was Nation of subjects and the dependent variables were evaluation scores. The evaluations of Samples E and E2 were analyzed in the same way as the evaluations of the six writing samples. 


\section{CHAPTER IV}

\section{RESULTS}

In this chapter, the results of the data analysis of the evaluations for the writing samples and the responses to the questionnaires are reported. First, the evaluations of the writing samples are analyzed between subject groups and across writing samples; then the evaluations of the writing samples are analyzed within each individual writing sample and the responses to the questionnaires are reported. The correlation between the evaluations and the perception of rhetorical differences by the American subjects is also reported in the first section, and the comparison of the evaluations between Sample E and its revised version, Sample E2, is reported in the second section. The evaluations by university instructors and those by university students or graduates are reported separately in each section.

\section{RESULTS OF ANALYSIS ACROSS THE WRITING SAMPLES}

The total scores of the evaluation categories (unity, focus, coherence, and holistic evaluation) were analyzed by ANOVA with a two factor mixed within-subject design. The two independent variables are the two groups of subjects (Nation) and the writing 
samples (Writing Sample), and the significance level for all calculations was set at .05 .

\section{Instructors}

The instructors in each group evaluated Writing Samples A, B, and $\mathrm{C}$. Table I shows the mean total scores and the standard deviations of the two groups of instructors. (See also Figure 2 for instructors' mean total scores.) The standard deviations of American instructors appear to be larger than those of Japanese instructors.

\section{TABLE I}

INSTRUCTORS' MEANS AND S.D.'S: TOTAL SCORE

\begin{tabular}{|c|c|c|c|c|c|c|}
\hline & \multicolumn{3}{|c|}{ Japan } & \multicolumn{3}{|c|}{ the U.S. } \\
\hline & Mean & S.D. & $\mathrm{N}$ & Mean & S.D. & $\mathrm{N}$ \\
\hline Sample A & 15.55 & 2.39 & 20 & 14.20 & 3.67 & 20 \\
\hline Sample B & 12.85 & 3.77 & 20 & 14.45 & 4.34 & 20 \\
\hline Sample C & 12.00 & 3.43 & 20 & 10.08 & 4.80 & 20 \\
\hline
\end{tabular}




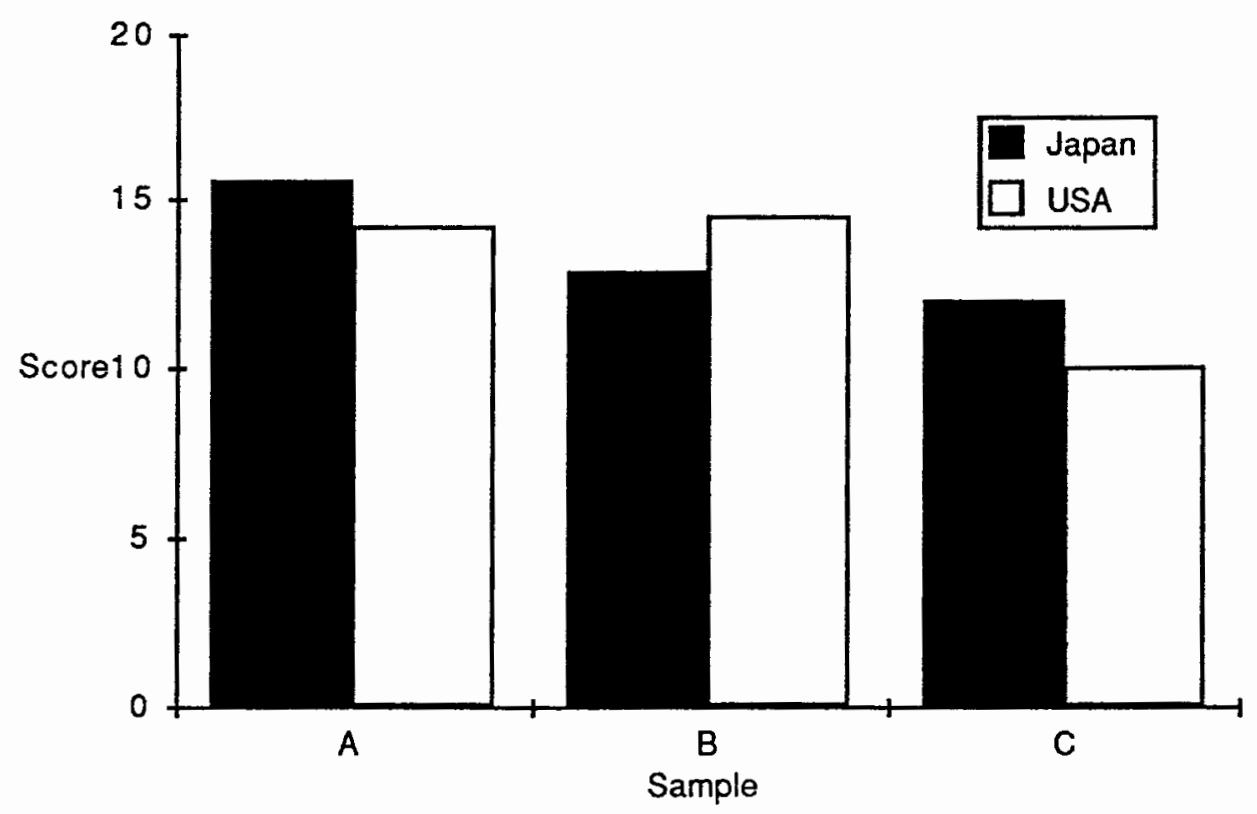

Figure 2. Instructors' Mean Total Scores.

However, as Table II indicates, the results of the instructors' total scores demonstrated no statistically significant differences between the subject groups (i.e. Japan and the United States) with a p-value of 0.562 . The evaluation across the writing samples showed significant differences with a p-value of less than 0.001 . This indicates that there was high agreement in evaluation between the two groups in each writing sample. However, there was significant interaction between two independent variables (i.e. Nation and Writing Samples) with a p-value of 0.027 as shown in Table II, suggesting that different subject groups evaluated different samples more highly than others. As can be seen in Table I, Japanese instructors conferred the highest scores on Sample A, while American instructors graded Sample B the highest. 
TABLE II

RESULTS OF INSTRUCTORS' EVALUATIONS: TOTAL SCORE

\begin{tabular}{|lcrrrr|}
\hline Source & df & SS (UM) & MSS & F-ratio & P-value \\
\hline Bet Subjs & 39 & 865.159 & & & \\
Nation & 1 & 7.712 & 7.712 & 0.342 & 0.562 \\
Sub w Grp & 38 & 857.448 & 22.564 & & \\
& & & & & \\
W Subj & 80 & 1267.704 & & & \\
Wr Smpls & 2 & 321.328 & 160.664 & 14.190 & $<0.001^{*}$ \\
N x WS & 2 & 85.893 & 42.947 & 3.793 & $0.027^{*}$ \\
WS x SwG & 76 & 860.484 & 11.322 & & \\
& & & & & \\
\hline
\end{tabular}

Note: ${ }^{*}=$ significant at alpha of .05

Table III shows the mean scores and the standard deviations of holistic evaluation by Japanese and American instructors. (See also Figure 3 for instructors' mean scores of holistic evaluation.) Two groups demonstrated considerable agreement in holistic evaluation. No significant differences were observed between subject groups with a p-value of 0.457 , along with significant differences across writing samples. There was no significant interaction between the two independent variables with a p-value of 0.251 as seen in Table IV. 
TABLE III

INSTRUCTORS' MEANS AND S.D.'S: HOLISTIC EVALUATION

\begin{tabular}{|llllllll|}
\hline & & Japan & \multicolumn{3}{c|}{ the U.S. } \\
\hline & Mean & S.D. & N & Mean & S.D. & N \\
\hline & & & & & & & \\
Sample A & 3.85 & 0.75 & 20 & 3.50 & 0.95 & 20 \\
Sample B & 3.35 & 1.04 & 20 & 3.55 & 1.21 & 20 \\
Sample C & 2.85 & 0.93 & 20 & 2.48 & 1.19 & 20 \\
\end{tabular}

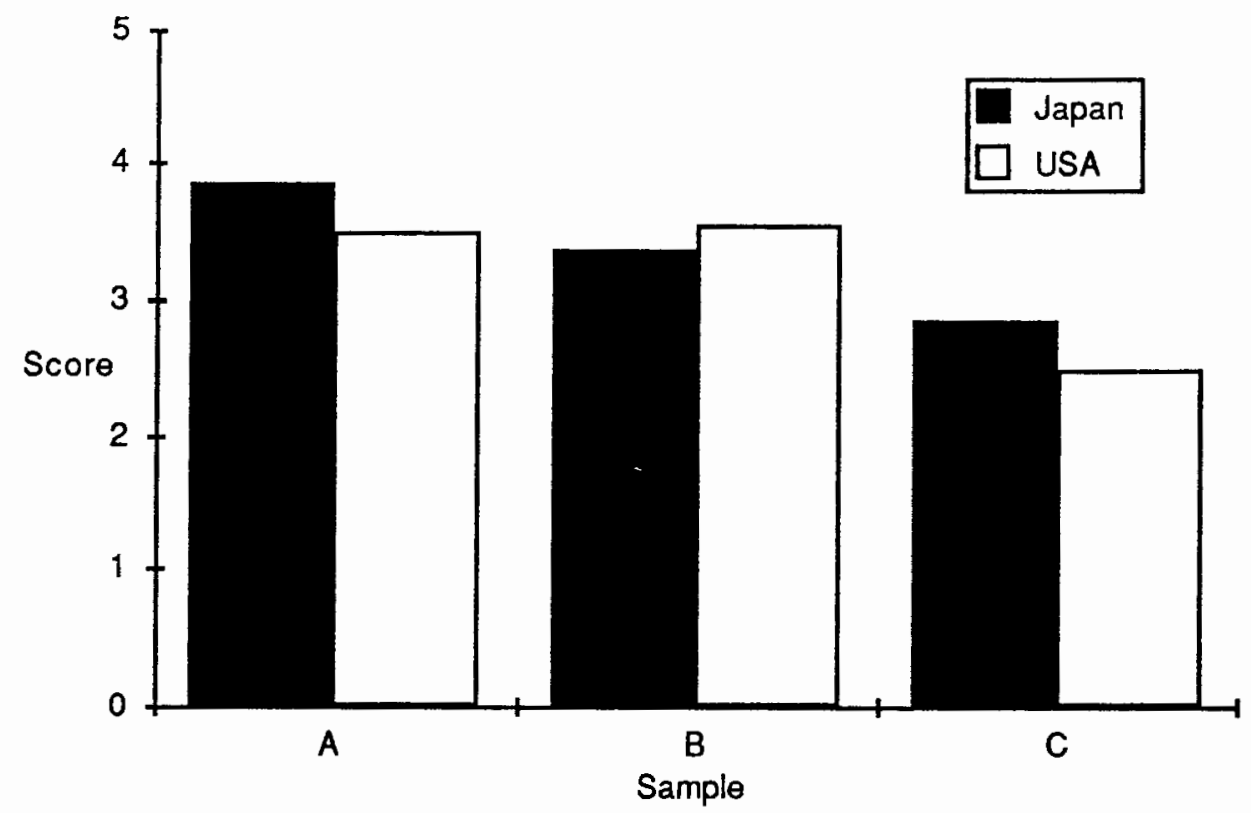

Figure 3. The Mean Scores of Instructors' Holistic Evaluation. 
TABLE IV

RESULTS OF INSTRUCTORS' EVALUATIONS: HOLISTIC EVALUATION

\begin{tabular}{|lcrrrr|}
\hline \multicolumn{1}{|c}{ Source } & df & SS (UM) & MSS & F-ratio & P-value \\
\hline Bet Subjs & 39 & 61.828 & & & \\
Nation & 1 & 0.905 & 0.905 & 0.564 & 0.457 \\
Sub w Grp & 38 & 60.923 & 1.603 & & \\
& & & & & \\
W Subj & 80 & 82.858 & & & \\
Wr Smpls & 2 & 22.643 & 11.321 & 14.816 & $<0.001^{*}$ \\
N x WS & 2 & 2.143 & 1.071 & 1.402 & 0.251 \\
WS x SwG & 76 & 58.072 & 0.764 & & \\
& & & & & \\
\hline
\end{tabular}

Note: ${ }^{*}=$ significant at alpha of .05

Tables V, VI, and VII respectively demonstrate the results of three evaluation categories - unity, focus, and coherence. (See Figure 4 for the mean scores of instructors' unity, Figure 5 for the mean scores of instructors' focus, and Figure 6 for the mean scores of instructors' coherence.) Their results were slightly different from those of the holistic evaluations. The instructors demonstrated no significant differences between the subject groups, while they did demonstrate significant differences across writing samples. Only a tendency toward differences between the subject groups was observed in the evaluations of coherence with a p-value of 0.077 . However, there was statistically significant interaction between the two independent variables (i.e. Nation and Writing Sample) in the evaluations of focus and coherence with, respectively, a p-value of 0.047 and 0.005 ; and there was a tendency toward interaction in the evaluations of unity with a p-value of 0.096 . 
The results indicate that although the two groups of instructors agreed on holistic evaluation, different subject groups graded different writing samples highly on unity, focus, and coherence.

There was disagreement especially over coherence. Japanese instructors considered Sample A as most coherent and Samples B and $\mathrm{C}$ as at the same level of coherence, while American instructors considered Sample B as the most coherent and Sample C as the least coherent.

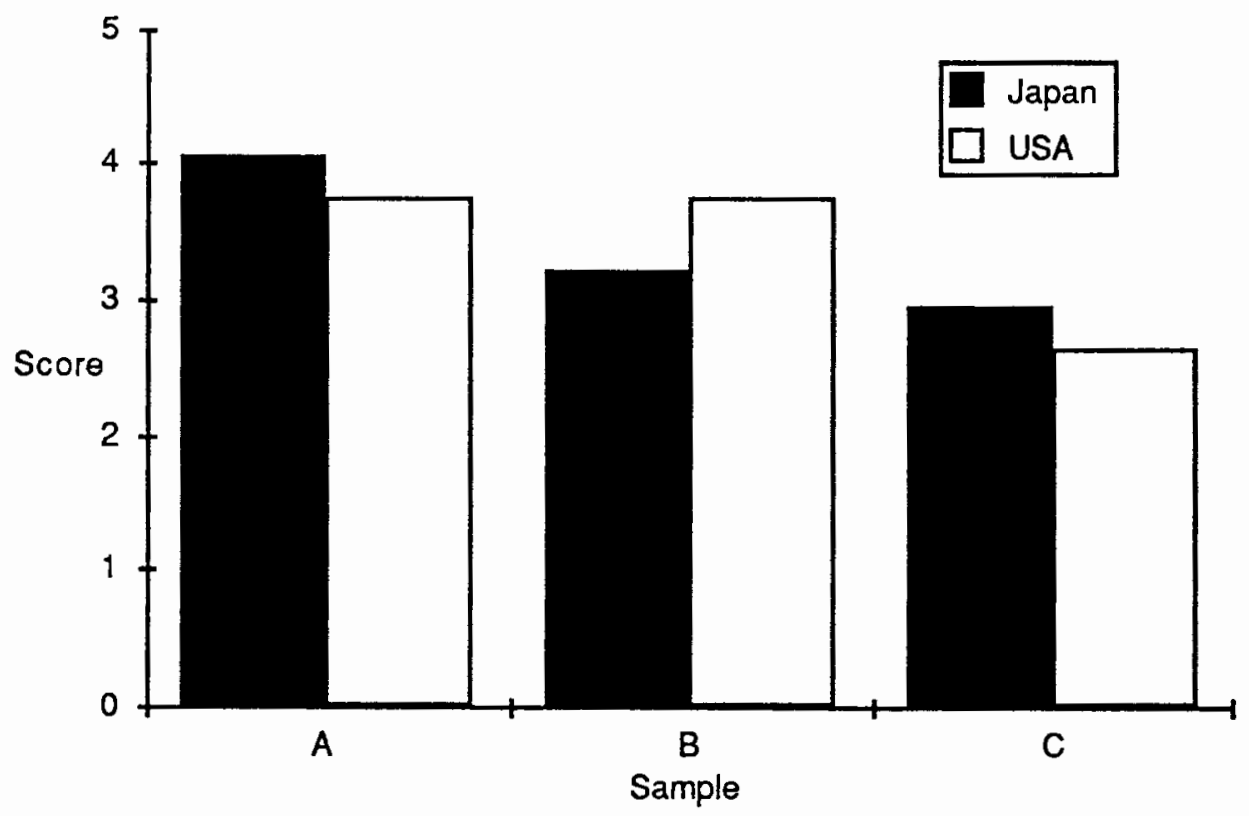

Figure 4. The Mean Scores of Instructors' Unity. 
TABLE V

RESULTS OF INSTRUCTORS' EVALUATIONS: UNITY

\begin{tabular}{|lcrrrr|}
\hline Source & $\mathrm{df}$ & SS (UM) & MSS & F-ratio & P-value \\
\hline Bet Subjs & 39 & 57.258 & & & \\
Nation & 1 & 0.008 & 0.008 & 0.006 & 0.941 \\
Sub w Grp & 38 & 57.250 & 1.507 & & \\
& & & & & \\
W Subj & 80 & 105.333 & & & \\
Wr Smpls & 2 & 24.617 & 12.308 & 12.325 & $<0.001 *$ \\
N x WS & 2 & 4.817 & 2.408 & 2.412 & 0.096 \\
WS x SwG & 76 & 75.900 & 0.999 & & \\
\end{tabular}

Note: ${ }^{*}=$ significant at alpha of .05

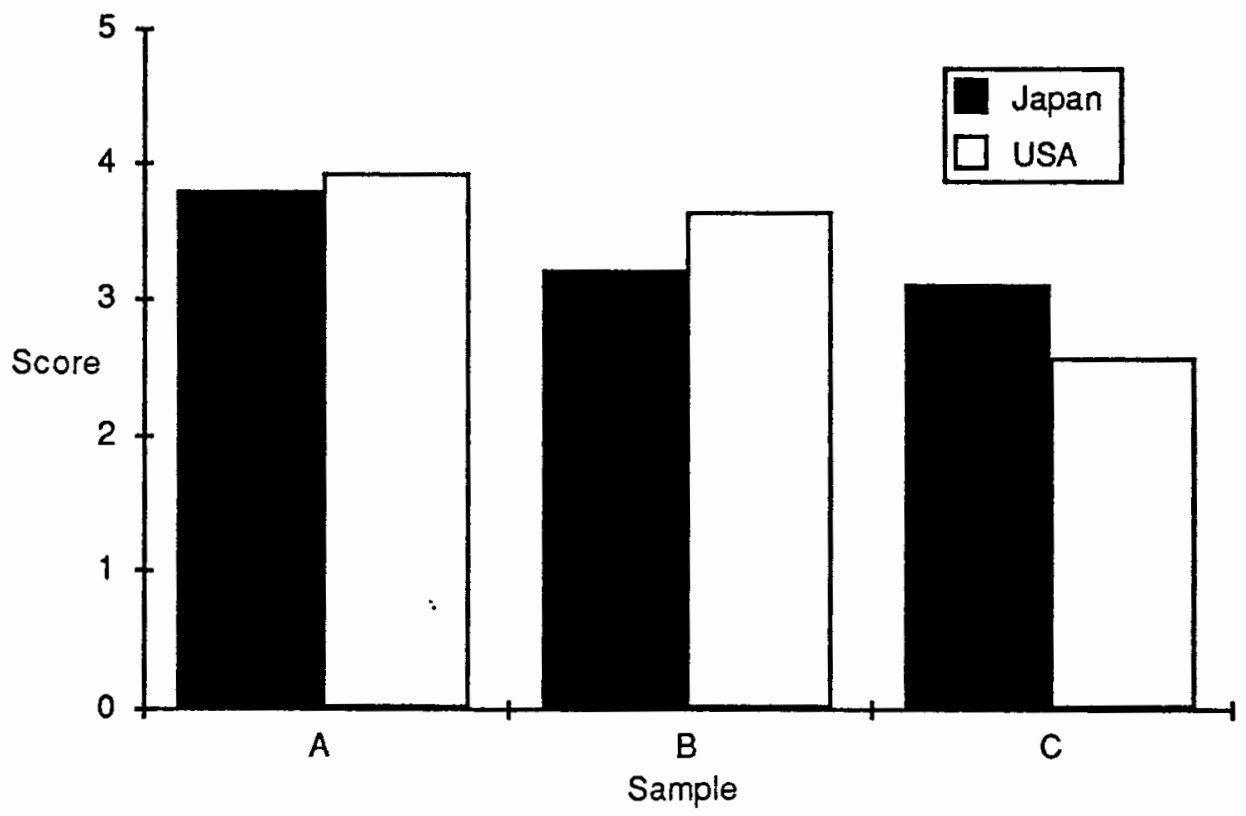

Figure 5. The Mean Scores of Instructors' Focus. 
TABLE VI

RESULTS OF INSTRUCTORS" EVALUATIONS: FOCUS

\begin{tabular}{|lcrrrr|}
\hline Source & df & SS (UM) & MSS & F-ratio & P-value \\
\hline Bet Subjs & 39 & 70.581 & & & \\
Nation & 1 & 0.002 & 0.002 & 0.001 & 0.973 \\
Sub w Grp & 38 & 70.579 & 1.857 & & \\
& & & & & \\
w Subj & 80 & 89.167 & & & \\
Wr Smpls & 2 & 21.704 & 10.852 & 13.247 & $<0.001^{*}$ \\
N x WS & 2 & 5.204 & 2.602 & 3.176 & $0.047^{*}$ \\
WS x SwG & 76 & 62.258 & 0.819 & & \\
& & & & & \\
\hline
\end{tabular}

Note: ${ }^{*}=$ significant at alpha of .05

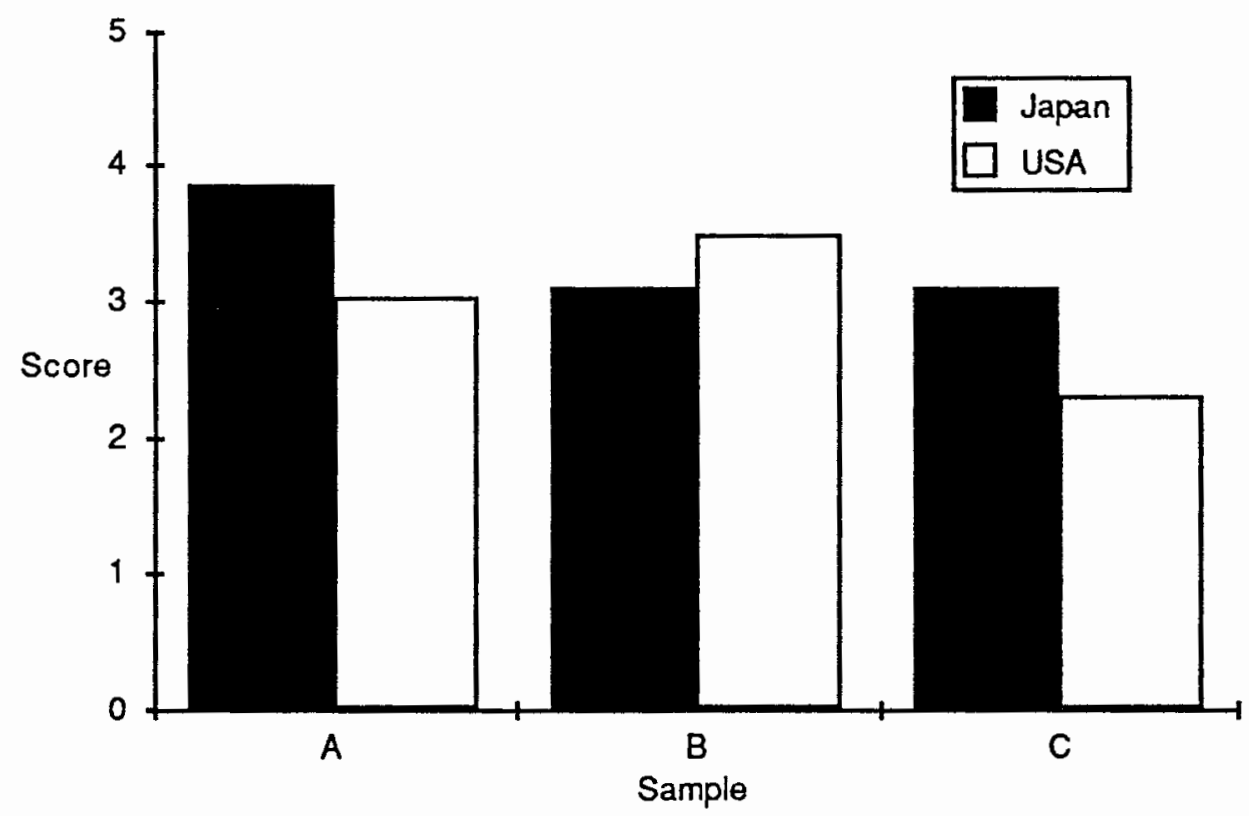

Figure 6. The Mean Scores of Instructors' Coherence. 
TABLE VII

RESULTS OF INSTRUCTORS' EVALUATIONS: COHERENCE

\begin{tabular}{|lcrrrr|}
\hline Source & df & SS (UM) & MSS & F-ratio & P-value \\
\hline Bet Subjs & 39 & 62.365 & & & \\
Nation & 1 & 5.002 & 5.002 & 3.314 & 0.077 \\
Sub w Grp & 38 & 57.363 & 1.510 & & \\
& & & & & \\
W Subj & 80 & 88.833 & & & \\
Wr Smpls & 2 & 12.304 & 6.152 & 7.007 & $0.002^{*}$ \\
N x WS & 2 & 9.804 & 4.902 & 5.583 & $0.005^{*}$ \\
WS x SwG & 76 & 66.725 & 0.878 & & \\
& & & & & \\
\hline
\end{tabular}

Note: ${ }^{*}=$ significant at alpha of .05

\section{University Students and Graduates}

University students and graduates evaluated Samples A, B, C, D, $E$, and F. These samples were evaluated by forty subjects from each country except Sample E. (Eighteen subjects completed the evaluation of all the categories for Sample E, and the other twenty evaluated Sample E2.) Therefore, first, the results of the evaluations for the five writing samples, A, B, C, D, and F, are reported. The total scores and standard deviations of each sample by each subject group are shown in Table VIII. (See also Figure 7 for students' mean total scores.) Similar to the standard deviations of the instructors, the standard deviations of the American students appear to be larger than those of the Japanese subjects.

As the results in Table IX show, the student subject groups demonstrated considerable agreement on the evaluations. There were no significant differences in the total scores of the evaluations 
between the subject groups with a p-value of 0.884 ; and there were significant differences across writing samples with a p-value of less than 0.001. No significant interaction between the two independent variables was observed with a p-value of 0.772 .

\section{TABLE VIII}

\section{STUDENTS' MEANS AND S.D.'S: TOTAL SCORE}

\begin{tabular}{|llllllll|}
\hline & \multicolumn{3}{c}{ Japan } & \multicolumn{3}{c|}{ the U.S. } \\
\hline & Mean & S.D. & N & Mean & S.D. & N \\
\hline & & & & & & \\
Sample A & 15.58 & 3.13 & 40 & 15.00 & 3.20 & 39 \\
Sample B & 14.08 & 3.29 & 40 & 13.82 & 4.22 & 39 \\
Sample C & 11.98 & 3.40 & 40 & 11.77 & 5.00 & 39 \\
Sample D & 13.25 & 3.10 & 40 & 14.03 & 4.07 & 39 \\
Sample F & 12.58 & 3.40 & 40 & 12.45 & 4.65 & 39 \\
& & & & & & \\
\hline
\end{tabular}

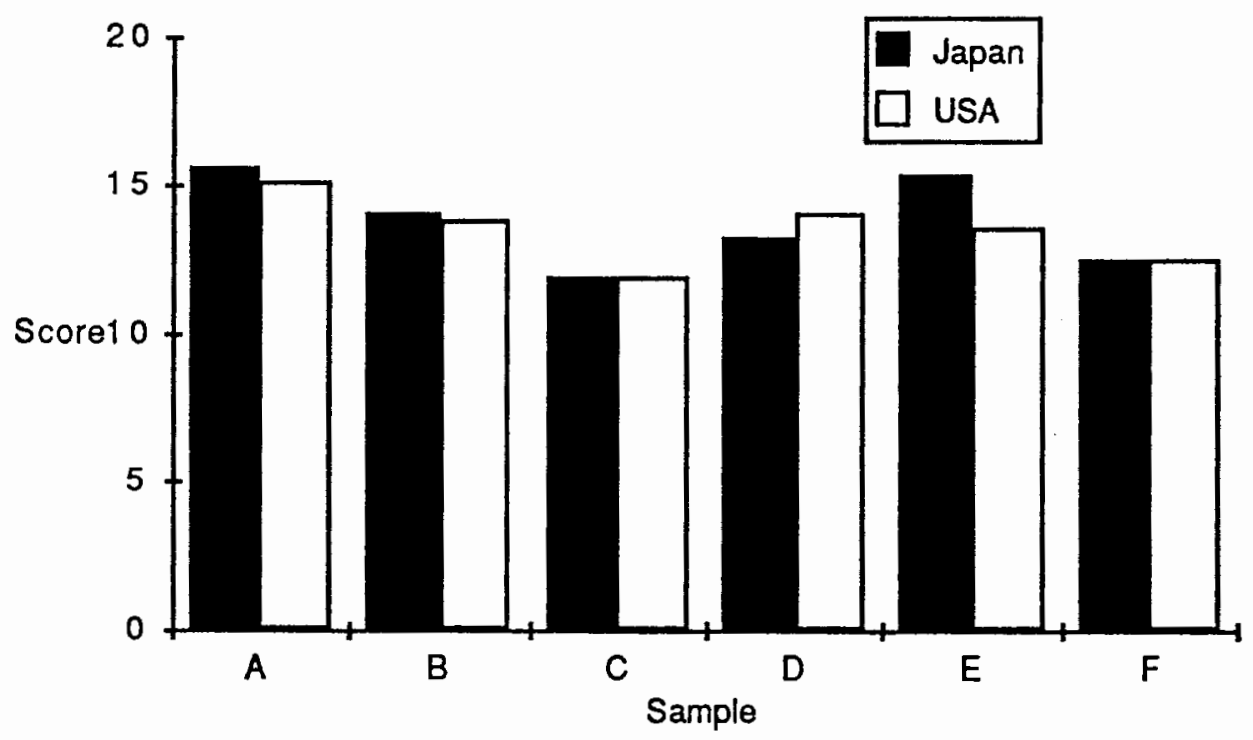

Figure 7. Students' Mean Total Scores. 
TABLE IX

RESULTS OF STUDENTS' EVALUATIONS: TOTAL SCORE

\begin{tabular}{|lcrrrr|}
\hline \multicolumn{1}{|c}{ Source } & df & SS (UM) & MSS & F-ratio & P-value \\
\hline Bet Subjs & 78 & 2102.387 & & & \\
Nation & 1 & 0.588 & 0.588 & 0.022 & 0.884 \\
Sub w Grp & 77 & 2101.799 & 27.296 & & \\
& & & & & \\
w Subj & 316 & 4022.199 & & & \\
Wr Smpls & 4 & 55.223 & 138.806 & 12.406 & $<0.001^{*}$ \\
N x WS & 4 & 20.251 & 5.066 & 0.452 & 0.772 \\
WS x SwG & 308 & 3446.041 & 11.188 & & \\
& & & & & \\
\hline
\end{tabular}

Note: ${ }^{*}=$ significant at alpha of .05

Similar results were found in the analysis of holistic evaluations. Tables $X$ and $X I$ show that students demonstrated no significant differences in evaluation between subject groups with a p-value of 0.747 , but did demonstrate significant differences across writing samples. (See also Figure 8 for the mean scores of students' holistic evaluation.) There was no significant interaction between the two independent variables. This indicates that there was considerable agreement on the evaluations of each writing sample between Japanese subjects and American subjects. 
TABLE $X$

STUDENTS' MEANS AND S.D.'S : HOLISTIC EVALUATION

\begin{tabular}{|lccccccc|}
\hline & \multicolumn{3}{c}{ Japan } & \multicolumn{3}{c|}{ the U.S. } \\
\hline & Mean & S.D. & N & Mean & S.D. & N \\
\hline & & & & & & & \\
Sample A & 3.95 & 0.94 & 40 & 3.80 & 0.83 & 39 \\
Sample B & 3.60 & 0.87 & 40 & 3.28 & 1.11 & 39 \\
Sample C & 2.98 & 0.95 & 40 & 2.98 & 1.17 & 40 \\
Sample D & 3.28 & 1.04 & 40 & 3.58 & 1.04 & 40 \\
Sample F & 3.13 & 0.94 & 40 & 3.14 & 1.31 & 40 \\
& & & & & & \\
\hline
\end{tabular}

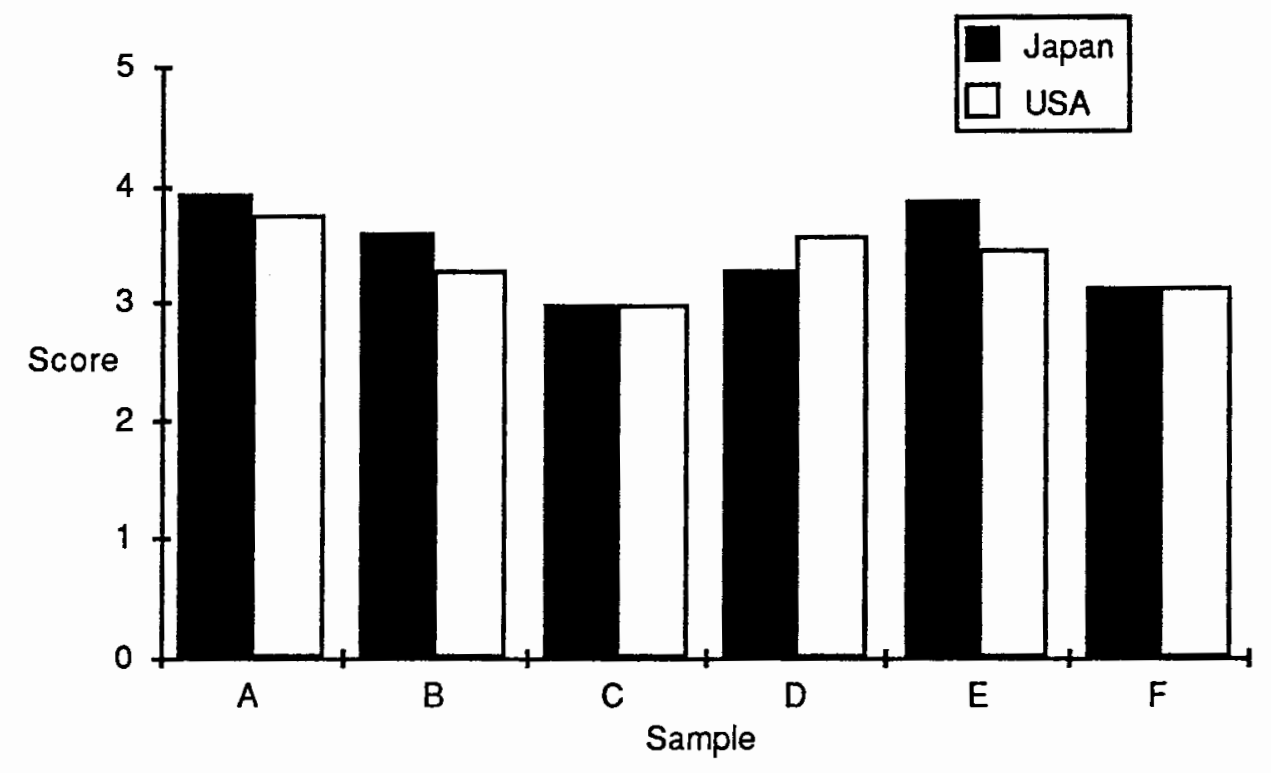

Figure 8. The Mean Scores of Students' Holistic Evaluation. 
TABLE XI

RESULTS OF STUDENTS' EVALUATIONS: HOLISTIC EVALUATION

\begin{tabular}{|lcrrrr|}
\hline \multicolumn{1}{|c}{ Source } & $\mathrm{df}$ & SS (UM) & MSS & F-ratio & P-value \\
\hline Bet Subjs & 79 & 134.724 & & & \\
Nation & 1 & 0.181 & 0.181 & 0.105 & 0.747 \\
Sub w Grp & 78 & 134.544 & 1.725 & & \\
& & & & & \\
w Subj & 320 & 278.600 & & & \\
Wr Smpls & 4 & 36.065 & 9.016 & 11.820 & $<0.001^{*}$ \\
N x WS & 4 & 4.535 & 1.134 & 1.486 & 0.205 \\
WS x SwG & 312 & 238.000 & 0.763 & & \\
& & & & & \\
\hline
\end{tabular}

Note: $*$ significant at alpha of .05

The analysis of the evaluations of the other three evaluation categories - unity, focus, and coherence - also demonstrated similar results as can be seen, respectively, in Tables XII, XIII, and XIV. (See Figure 9 for the mean scores of students' unity, Figure 10 for the mean scores of students' focus, and Figure 11 for the mean scores of students' coherence.) There were no significant differences between the subject groups; and significant differences were observed in the evaluations across the writing samples. There was also no significant interaction between the two independent variables. Only the evaluations of coherence revealed a tendency toward difference between the subject groups with a p-value of 0.095 and a tendency toward interaction between the two independent variables with a pvalue of 0.092 . These results indicate that the two student subject 
groups agreed with each other on the evaluations of the Writing Samples A, B, C, D, and F except in the category of coherence.

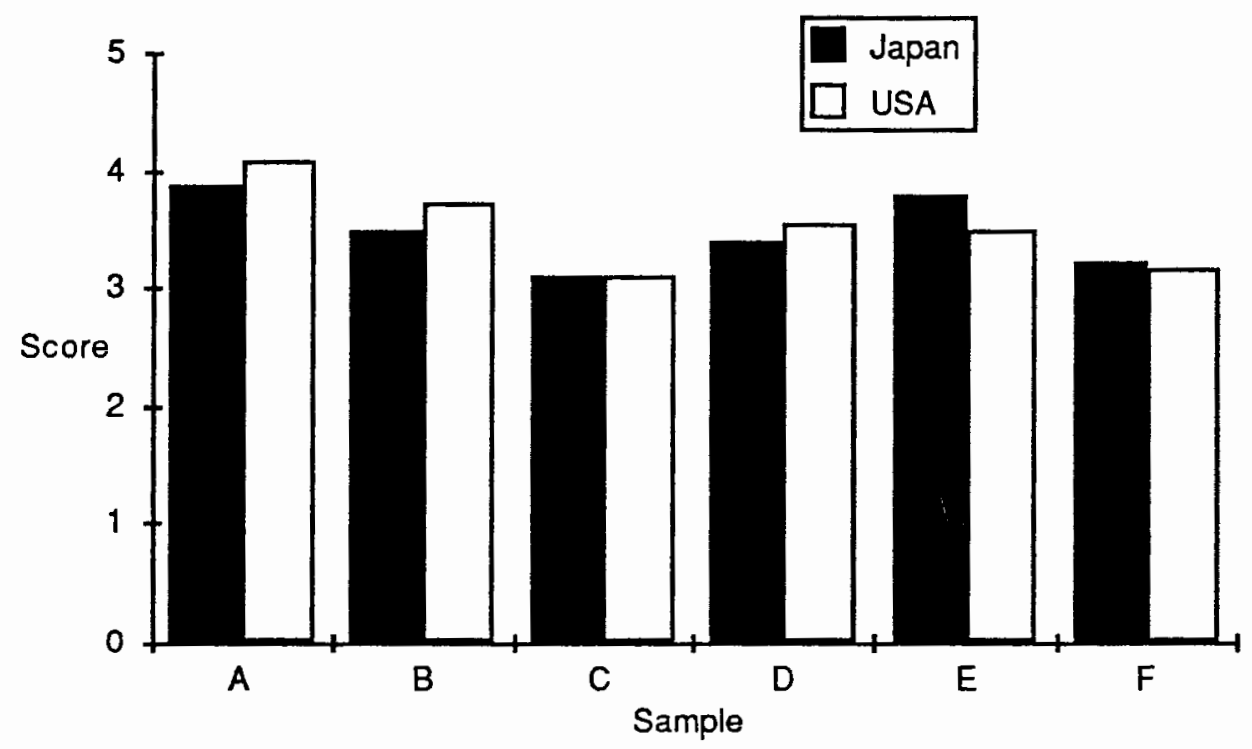

Figure 9. The Mean Scores of Students' Unity.

\author{
TABLE XII
}

RESULTS OF STUDENTS' EVALUATIONS: UNITY

\begin{tabular}{|lcrrrr|}
\hline \multicolumn{1}{|c}{ Source } & df & SS (UM) & MSS & F-ratio & P-value \\
\hline Bet Subjs & 78 & 126.461 & & & \\
Nation & 1 & 0.757 & 0.757 & 0.464 & 0.498 \\
Sub w Grp & 77 & 125.704 & 1.633 & & \\
& & & & & \\
w Subj & 316 & 321.600 & & & \\
Wr Smpls & 4 & 38.925 & 9.731 & 10.655 & $<0.001^{*}$ \\
N x WS & 4 & 1.548 & 0.387 & 0.424 & 0.793 \\
WS x SwG & 308 & 281.283 & 0.913 & & \\
& & & & & \\
\hline
\end{tabular}

Note: ${ }^{*}=$ significant at alpha of .05 


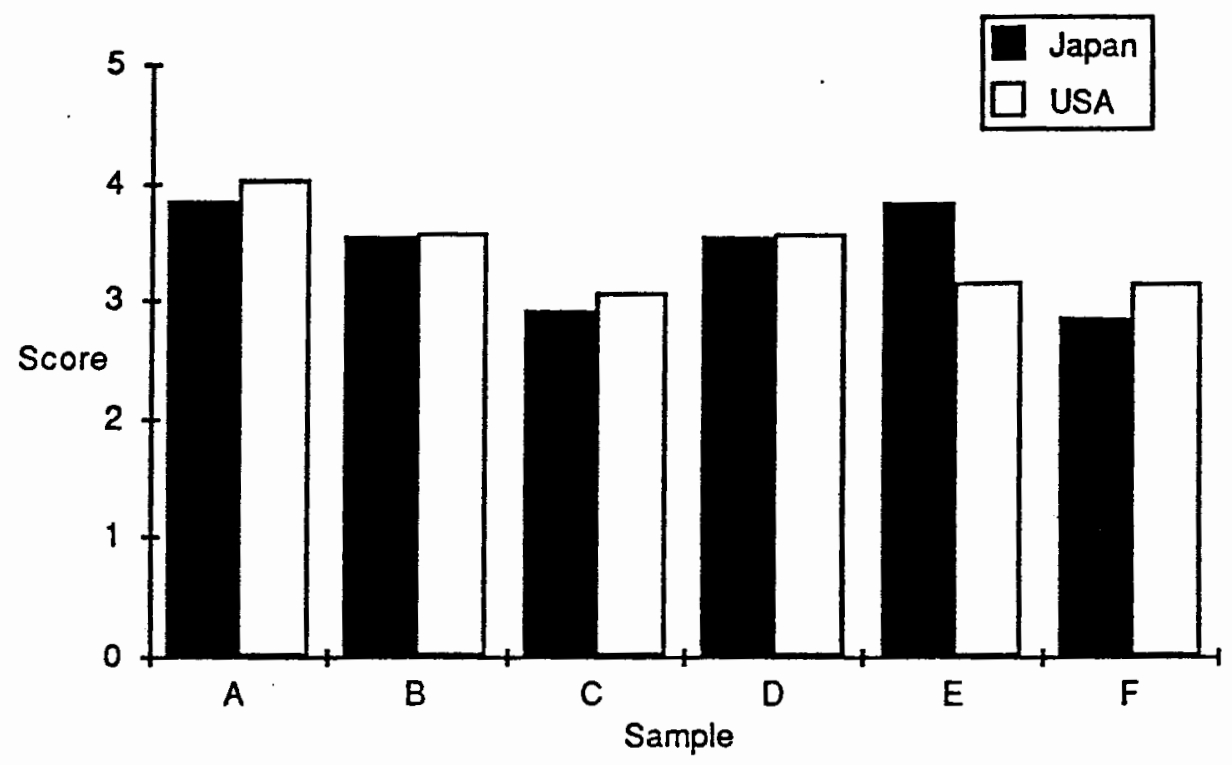

Figure 10. The Mean Scores of Students' Focus.

\section{TABLE XIII}

RESULTS OF STUDENTS" EVALUATIONS: FOCUS

\begin{tabular}{|lcrrrr|}
\hline \multicolumn{1}{|c}{ Source } & df & SS (UM) & MSS & F-ratio & P-value \\
\hline Bet Subjs & 78 & 167.676 & & & \\
Nation & 1 & 2.116 & 2.116 & 0.984 & 0.324 \\
Sub w Grp & 77 & 165.560 & 2.150 & & \\
& & & & & \\
w Subj & 316 & 337.600 & & & \\
Wr Smpls & 4 & 50.876 & 12.719 & 13.690 & $<0.001 *$ \\
N x WS & 4 & 0.526 & 0.132 & 0.142 & 0.967 \\
WS x SwG & 308 & 286.152 & 0.929 & & \\
& & & & & \\
\hline
\end{tabular}

Note: $*=$ significant at alpha of .05 


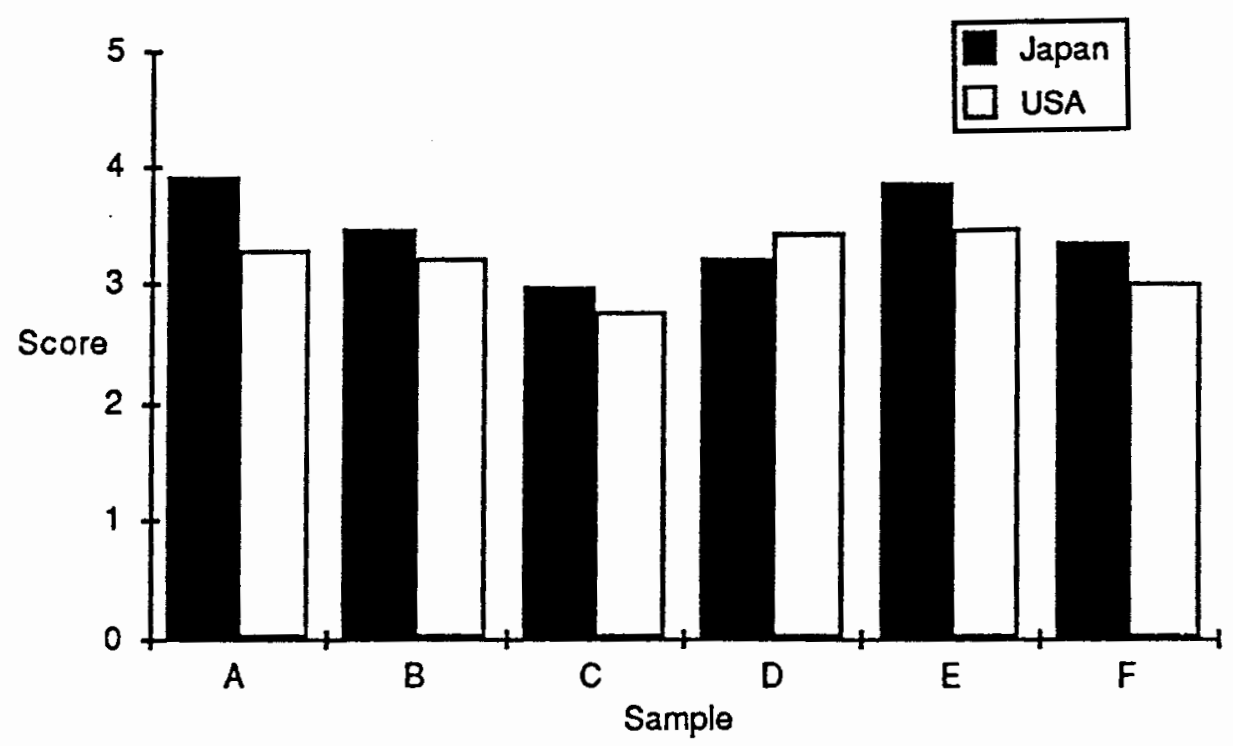

Figure 11. The Mean Scores of Students' Coherence.

\section{TABLE XIV}

RESULTS OF STUDENTS' EVALUATIONS: COHERENCE

\begin{tabular}{|lcrrrr|}
\hline Source & $\mathrm{df}$ & SS (UM) & MSS & F-ratio & P-value \\
\hline Bet Subjs & 78 & 174.775 & & & \\
Nation & 1 & 6.260 & 6.260 & 2.860 & 0.095 \\
Sub w Grp & 77 & 168.515 & 2.189 & & \\
& & & & & \\
W Subj & 316 & 290.400 & & & \\
Wr Smpls & 4 & 20.983 & 5.246 & 6.156 & $<0.001^{*}$ \\
N x WS & 4 & 6.856 & 1.714 & 2.011 & 0.092 \\
WS x SwG & 308 & 262.445 & 0.852 & & \\
& & & & & \\
\hline
\end{tabular}

Note: ${ }^{*}=$ significant at alpha of .05

The results including Sample E demonstrated a slight difference from those excluding Sample E. Similar to the results reported above, no significant differences were observed in the evaluations 
between the subject groups with a p-value of 0.781 ; and the evaluations of each writing sample were significantly different.

However, there was a tendency toward interaction between the two independent variables with a p-value of 0.077 as shown in Table XV.

\section{TABLE XV}

\section{RESULTS OF STUDENTS' EVALUATIONS WITH SAMPLE E: TOTAL SCORE}

\begin{tabular}{|lcrrrr|}
\hline \multicolumn{1}{|c}{ Source } & df & SS (UM) & MSS & F-ratio & P-value \\
\hline Bet Subjs & 57 & 1710.874 & & & \\
Nation & 1 & 2.391 & 2.391 & 0.078 & 0.781 \\
Sub w Grp & 56 & 1710.483 & 30.509 & & \\
& & & & & \\
W Subj & 290 & 2897.377 & & & \\
Wr Smpls & 5 & 303.017 & 60.603 & 7.138 & $<0.001^{*}$ \\
N x WS & 5 & 85.275 & 17.055 & 2.009 & 0.077 \\
WS x SwG & 280 & 2377.372 & 8.491 & & \\
& & & & & \\
\hline
\end{tabular}

Note: ${ }^{*}=$ significant at alpha of .05

As can be seen in Table XVI, similar results were observed in the analysis of holistic evaluation, demonstrating no significant differences in the evaluation between the subject groups along with significant differences in the evaluation of each writing sample. However, a tendency toward interaction of the two independent variables was observed with a p-value of 0.111 . 
TABLE XVI

RESULTS OF STUDENTS' EVALUATIONS WITH

SAMPLE E: HOLISTIC EVALUATION

\begin{tabular}{|lcrrrr|}
\hline Source & df & SS (UM) & MSS & F-ratio & P-value \\
\hline Bet Subjs & 58 & 113.439 & & & \\
Nation & 1 & 0.131 & 0.131 & 0.066 & 0.798 \\
Sub w Grp & 57 & 113.308 & 1.988 & & \\
& & & & & \\
w Subj & 295 & 215.042 & & & \\
Wr Smpls & 5 & 20.588 & 4.118 & 6.571 & $<0.001^{*}$ \\
N x WS & 5 & 5.662 & 1.132 & 1.807 & 0.111 \\
WS x SwG & 285 & 178.603 & 0.627 & & \\
& & & & & \\
\hline
\end{tabular}

Note: ${ }^{*}=$ significant at alpha of .05

Among the three evaluation categories, the subject groups revealed considerable agreement on the evaluation of unity. However, significant interaction between the two independent variables (Nation and Writing Sample) was observed in the evaluation of focus with a p-value of 0.005 , and there was a tendency toward interaction between the two independent variables in regard to coherence with a p-value of 0.072 .

The results indicate that the two groups of students demonstrated considerable agreement on holistic evaluations of each writing sample, although a tendency that different student groups evaluated different writing samples highly was observed. In regard to individual evaluation categories, the results suggest that different subject groups appeared to have different expectations toward coherence and focus. 
Correlation between Evaluation and Rhetorical Differences

The correlation between the evaluation and the perception of rhetorical differences was analyzed by Pearson's Product-moment correlation, as shown in Table XVII and XVIII. Both instructors' and students' evaluations demonstrated a high positive correlation except in instructors' evaluations of Sample B, suggesting that American readers expect rhetorical patterns close to English discourse.

\section{TABLE XVII}

CORRELATION BETWEEN EVALUATIONS AND RHETORICAL DIFFERENCES: AMERICAN INSTRUCTORS

\begin{tabular}{|lllllllc|}
\hline & \multicolumn{3}{c}{ Total Scores } & \multicolumn{3}{c|}{ Holistic Evaluation } \\
\hline & $\mathrm{N}$ & Ratio & P-val & $\mathrm{N}$ & Ratio & P-val \\
\hline & & & & & & & \\
Sample & A & 19 & 0.568 & $0.011^{*}$ & 19 & 0.585 & $0.009^{*}$ \\
Sample & B & 20 & 0.296 & 0.205 & 20 & 0.291 & 0.213 \\
Sample & C & 19 & 0.780 & $<0.001^{*}$ & 19 & 0.723 & $<0.001^{*}$ \\
& & & & & & & \\
\hline
\end{tabular}

Note: ${ }^{*}=$ significant at alpha of .05 


\section{TABLE XVIII}

CORRELATION BETWEEN EVALUATIONS AND RHETORICAL DIFFERENCES: AMERICAN STUDENTS

\begin{tabular}{|lrrrrrrr|}
\hline & \multicolumn{3}{c}{ Total Scores } & \multicolumn{3}{c|}{ Holistic Evaluation } \\
\hline & N & Ratio & P-val & N & Ratio & P-val \\
\hline & & & & & & & \\
Sample A & 39 & 0.436 & $0.005^{*}$ & 39 & 0.424 & $0.007^{*}$ \\
Sample B & 40 & 0.522 & $0.001^{*}$ & 40 & 0.634 & $<0.001^{*}$ \\
Sample C & 40 & 0.778 & $<0.001^{*}$ & 40 & 0.744 & $<0.001^{*}$ \\
Sample D & 38 & 0.902 & $<0.001^{*}$ & 38 & 0.837 & $<0.001^{*}$ \\
Sample E & 19 & 0.717 & $<0.001^{*}$ & 19 & 0.644 & $0.003^{*}$ \\
Sample F & 39 & 0.859 & $<0.001^{*}$ & 39 & 0.877 & $<0.001^{*}$ \\
& & & & & & \\
\hline
\end{tabular}

Note: ${ }^{*}=$ significant at alpha of .05

\section{RESULTS OF ANALYSIS WITHIN EACH WRITING SAMPLE}

For each writing sample, two-tailed $t$-tests with separate variances were used for the analysis between the two countries for each writing sample. Total scores and scores for each category were compared between subject groups. The results of the questionnaires are also reported for each sample.

\section{Sample A}

The structure of this essay could be outlined as follows. It begins with a specific incident: a race horse who was defeated in an important race drooped his head, his eyes filled with tears. The topic of the essay, that is whether horses shed tears of emotion, is stated indirectly in the third paragraph, although the content of the first two paragraphs relates to the topic. In the following three 
paragraphs, the author discusses the topic first by introducing opposing evidence, then by providing support that apparently relates only remotely to the thesis. The thesis of the essay is stated indirectly at the end of the last paragraph as "it does not seem unnatural even if horses have 'tears of emotion."

The results of the evaluation were not significant. Both instructors' and students' evaluations demonstrated no significant differences between the two countries in the total scores and the holistic evaluations as shown in Table XIX and XX. All the subject groups gave comparatively high scores to this writing sample. However, an F-max test showed that the variances of the total scores among American instructors were significantly larger than for the Japanese instructors. This indicates that the evaluation of American instructors varied considerably within the group, relative to the Japanese instructors. Among other evaluation categories, both instructors' and students' evaluations for coherence demonstrated significant differences between the two countries respectively with a p-value of 0.010 and 0.005 . In addition, an F-max test showed that the variances among the American instructors were significantly larger than those among the Japanese instructors in the evaluations for unity and focus. 
TABLE XIX

INSTRUCTORS: SAMPLE A COMPARISONS OF EVALUATIONS

\begin{tabular}{|c|c|c|c|c|c|}
\hline & & Japan & the U.S. & Separate & Variances \\
\hline Total & $\begin{array}{c}\mathrm{N} \\
\text { Mean } \\
\text { S.D. }\end{array}$ & $\begin{array}{c}20 \\
15.550 \\
2.395\end{array}$ & $\begin{array}{c}20 \\
14.200 \\
3.672\end{array}$ & $\begin{array}{c}\mathrm{T} \\
\mathrm{df} \\
\mathrm{P}\end{array}$ & $\begin{array}{c}1.38 \\
32.68 \\
0.178\end{array}$ \\
\hline Hol Ev. & $\begin{array}{c}\mathrm{N} \\
\text { Mean } \\
\text { S.D. }\end{array}$ & $\begin{array}{c}20 \\
3.850 \\
0.745\end{array}$ & $\begin{array}{l}20 \\
3.500 \\
0.946\end{array}$ & $\begin{array}{c}T \\
d f \\
P\end{array}$ & $\begin{array}{c}1.30 \\
36.03 \\
0.202\end{array}$ \\
\hline Unity & $\begin{array}{c}\mathrm{N} \\
\text { Mean } \\
\text { S.D. }\end{array}$ & $\begin{array}{c}20 \\
4.050 \\
0.605\end{array}$ & $\begin{array}{c}20 \\
3.750 \\
1.118\end{array}$ & $\begin{array}{c}\mathrm{T} \\
\mathrm{df} \\
\mathrm{P}\end{array}$ & $\begin{array}{c}1.06 \\
29.24 \\
0.300 \dagger\end{array}$ \\
\hline Focus & $\begin{array}{c}\mathrm{N} \\
\text { Mean } \\
\text { S.D. }\end{array}$ & $\begin{array}{c}20 \\
3.800 \\
0.616\end{array}$ & $\begin{array}{c}20 \\
3.925 \\
1.055\end{array}$ & $\begin{array}{c}T \\
d f \\
P\end{array}$ & $\begin{array}{c}-0.46 \\
30.60 \\
0.650 \dagger\end{array}$ \\
\hline coherence & $\begin{array}{c}\mathrm{N} \\
\text { Mean } \\
\text { S.D. }\end{array}$ & $\begin{array}{c}20 \\
3.850 \\
0.616\end{array}$ & $\begin{array}{c}20 \\
3.025 \\
1.094\end{array}$ & $\begin{array}{l}\mathrm{T} \\
\mathrm{df} \\
\mathrm{P}\end{array}$ & $\begin{array}{c}2.71 \\
35.08 \\
0.010^{*}\end{array}$ \\
\hline
\end{tabular}

Note: $*$ = significant at .05

$\dagger=\mathrm{F}$ test of equal variances rejected at alpha of .05 
TABLE XX

STUDENTS: SAMPLE A COMPARISON OF EVALUATIONS

\begin{tabular}{|c|c|c|c|c|c|}
\hline & & Japan & the U.S. & Separate & Variances \\
\hline \multirow{3}{*}{ Total } & $\mathrm{N}$ & 40 & 39 & $T$ & 0.41 \\
\hline & Mean & 15.575 & 15.282 & $\mathrm{df}$ & 76.81 \\
\hline & S.D. & 3.129 & 3.203 & $\mathbf{P}$ & 0.682 \\
\hline \multirow[t]{3}{*}{ Hol Ev. } & $\mathrm{N}$ & 40 & 39 & $\mathrm{~T}$ & 0.85 \\
\hline & Mean & 3.950 & 3.795 & $\mathrm{df}$ & 76.42 \\
\hline & S.D. & 0.783 & 0.833 & $\mathrm{P}$ & 0.3965 \\
\hline \multirow{3}{*}{ Unity } & $\mathrm{N}$ & 40 & 40 & $\mathrm{~T}$ & -0.96 \\
\hline & Mean & 3.875 & 4.075 & $d f$ & 77.96 \\
\hline & S.D. & 0.939 & 0.917 & $P$ & 0.338 \\
\hline \multirow[t]{3}{*}{ Focus } & $\mathrm{N}$ & 40 & 40 & $\mathrm{~T}$ & -0.86 \\
\hline & Mean & 3.850 & 4.025 & $\mathrm{df}$ & 77.91 \\
\hline & S.D. & 0.921 & 0.891 & $\mathrm{P}$ & 0.390 \\
\hline \multirow[t]{3}{*}{ Coherence } & $\mathrm{N}$ & 40 & 40 & $\mathrm{~T}$ & 2.87 \\
\hline & Mean & 3.900 & 3.300 & $d f$ & 75.33 \\
\hline & S.D. & 0.841 & 1.018 & $\mathbf{P}$ & $0.005^{*}$ \\
\hline
\end{tabular}

Note: ${ }^{*}=$ significant at .05

American readers' responses to the questionnaires are reflected in the large value of their standard deviations. Some considered Sample A to have similar structures and coherence to English essays; others felt that it was considerably different. The differences pointed out by many American readers appear to be common to the characteristics of Japanese written discourse discussed in Chapter II of this study. 
In accord with the results of the statistical analysis, many subjects suggested that Sample A lacked coherence and smooth transitions. One of the students observed:

Cohesive devices (clues) were missing and that tends to render confusion -- or lack of "flow" when reading.

Another student stated:

The whole essay sounds like a long conversation (onesided). Not good transition, jumping from subject to subject, back and forth.

Some of those who viewed the structure of this essay as similar to an English essay also noticed differences in coherence. One of them pointed out indirect and implicit coherence, stating:

Paragraph six at first seems out of place, but when you read on, it makes a lot of sense. There is no definite cohesive device to introduce it, but a lot of coherence.

Some found differences in the thesis statement and conclusion. Following are comments by, respectively, an instructor and a student:

No conclusion or introduction or thesis [is] attempted.

Central idea or thesis is presented a third of the way into the essays rather than initially. Conclusion does not seem very comprehensive; it seems somewhat "spare" or "sparse." 
In similar fashion, it was pointed out that the essay did not have a clear thesis and was concluded differently from English essays.

Differences were also recognized in the structure of paragraphs. Some observed that there was a lack of topic sentences and that sentences in a paragraph did not necessarily adhere to one topic. One instructor remarked:

The paper doesn't seem to have clear topic sentences with everything in that paragraph supporting that topic sentence. There is no topic sentence about what is going to be proven.

Such a comment supports the studies by Hinds and Sakuma in which they claim that there are differences in paragraphing between the Japanese language and the English language.

Other differences were also recognized by American readers. Some noticed repetition of words, for example, "vexation," within and across paragraphs. A few commented that the use of the first person subject "I" was too informal for academic writing.

Although many of the readers, as discussed above, indicated certain features as differences, one instructor provided the following comment:

I don't see this composition as being significantly different from one of my English composition essays. Both typically suffer from general incoherence, failure to make transition between sentences and paragraphs, unnecessary repetition, and mostly, weakness in the logic and argumentative support for the thesis. Concerning this essay, where is its thesis? It lacks emphasis. 
Moreover, the connection between feeling and thinking is never established.

This presents a very clear contrast with the following remark by one of the Japanese instructors. He stated:

Judging from the impression after perusing the writing samples, each of them seemed for me to be first-class writing. In "Rudolf's Tears," a question is posed, and the discussion progresses skillfully from counter arguments to a supporting argument. Furthermore, the essay appears to imply an introspection against anthropocentricity. I evaluated the essay most highly.

These two remarks suggest that the same composition could be perceived very differently between the two countries. Further, it is quite possible that the characteristics of writing that are valued highly in one country are valued negatively in the other country.

\section{Sample B}

This sample possesses characteristics of a typical traditional Japanese essay, exhibiting a traditional organizational pattern $k i$-shoten-ketsu and using the first person subject "I." In the first two paragraphs, $k i$ and sho, the author relates his experience in reading. He describes how he reads and puts marks in books in $k i$, referring to the satisfaction he obtains from reading. In sho the author develops the same topic further. He states that he becomes disappointed upon finding that the marked places in the book do not really capture the nature of the book when he skims back over it. However, in the next paragraph, ten, the author changes the topic 
and states that only "art" can capture the nature of life. In the conclusion, ketsu, the author expresses his view that an outstanding work of art is an exclamation point which is placed on the crucial points of life.

Again, the results of the evaluations were not significantly different, as shown in Tables XXI and XXII. Students in both countries, especially, provided very similar scores in each category. It is, however, notable that American instructors evaluated Sample B more highly in all the categories than did Japanese instructors, although the results were not statistically significant. American instructors scored this sample the highest of the three. In regard to standard deviations, each group demonstrated larger standard deviations for Sample B than Sample A. 
TABLE XXI

INSTRUCTORS: SAMPLE B COMPARISON OF EVALUATIONS

\begin{tabular}{|c|c|c|c|c|c|}
\hline & & Japan & the U.S. & Separate & Variances \\
\hline Total & $\begin{array}{c}\mathrm{N} \\
\text { Mean } \\
\text { S.D. }\end{array}$ & $\begin{array}{c}20 \\
12.850 \\
3.774\end{array}$ & $\begin{array}{c}20 \\
14.704 \\
4.796\end{array}$ & $\begin{array}{c}T \\
d f \\
P\end{array}$ & $\begin{array}{l}-1.36 \\
36.01 \\
0.183\end{array}$ \\
\hline Hol Ev. & $\begin{array}{c}\text { N } \\
\text { Mean } \\
\text { S.D. }\end{array}$ & $\begin{array}{c}20 \\
3.350 \\
1.040\end{array}$ & $\begin{array}{c}20 \\
3.554 \\
1.205\end{array}$ & $\begin{array}{c}T \\
d f \\
P\end{array}$ & $\begin{array}{l}-0.57 \\
37.20 \\
0.570\end{array}$ \\
\hline Unity & $\begin{array}{c}\mathrm{N} \\
\text { Mean } \\
\text { S.D. }\end{array}$ & $\begin{array}{c}20 \\
3.200 \\
1.005\end{array}$ & $\begin{array}{c}20 \\
3.750 \\
1.118\end{array}$ & $\begin{array}{c}T \\
d f \\
P\end{array}$ & $\begin{array}{l}-1.64 \\
37.58 \\
0.110\end{array}$ \\
\hline Focus & $\begin{array}{c}\mathrm{N} \\
\text { Mean } \\
\text { S.D. }\end{array}$ & $\begin{array}{c}20 \\
3.200 \\
1.105\end{array}$ & $\begin{array}{c}20 \\
3.650 \\
1.309\end{array}$ & $\begin{array}{c}T \\
d f \\
P\end{array}$ & $\begin{array}{l}-1.17 \\
36.96 \\
0.248\end{array}$ \\
\hline Coherence & $\begin{array}{c}\mathrm{N} \\
\text { Mean } \\
\text { S.D. }\end{array}$ & $\begin{array}{c}20 \\
3.100 \\
1.071\end{array}$ & $\begin{array}{c}20 \\
3.500 \\
1.147\end{array}$ & $\begin{array}{c}T \\
d f \\
P\end{array}$ & $\begin{array}{l}-1.14 \\
37.82 \\
0.262\end{array}$ \\
\hline
\end{tabular}




\section{TABLE XXII}

STUDENTS: SAMPLE B COMPARISON OF EVALUATIONS

\begin{tabular}{|c|c|c|c|c|c|}
\hline & & Japan & the U.S. & Separate & Variances \\
\hline Total & $\begin{array}{c}\mathrm{N} \\
\text { Mean } \\
\text { S.D. }\end{array}$ & $\begin{array}{c}40 \\
14.075 \\
3.292\end{array}$ & $\begin{array}{c}39 \\
13.821 \\
4.223\end{array}$ & $\begin{array}{c}T \\
d f \\
P\end{array}$ & $\begin{array}{c}0.30 \\
71.81 \\
0.766\end{array}$ \\
\hline Hol Ev. & $\begin{array}{c}\mathrm{N} \\
\text { Mean } \\
\text { SD. }\end{array}$ & $\begin{array}{c}40 \\
3.600 \\
0.871\end{array}$ & $\begin{array}{c}40 \\
3.275 \\
1.109\end{array}$ & $\begin{array}{c}T \\
d f \\
P\end{array}$ & $\begin{array}{c}1.46 \\
73.86 \\
0.149\end{array}$ \\
\hline Unity & $\begin{array}{c}\mathrm{N} \\
\text { Mean } \\
\text { SD. }\end{array}$ & $\begin{array}{c}40 \\
3.475 \\
0.847\end{array}$ & $\begin{array}{c}39 \\
3.718 \\
1.099\end{array}$ & $\begin{array}{c}T \\
d f \\
P\end{array}$ & $\begin{array}{l}-1.10 \\
71.42 \\
0.276\end{array}$ \\
\hline Focus & $\begin{array}{c}N \\
\text { Mean } \\
\text { S.D. }\end{array}$ & $\begin{array}{c}40 \\
3.550 \\
0.932\end{array}$ & $\begin{array}{c}39 \\
3.590 \\
1.229\end{array}$ & $\begin{array}{c}T \\
d f \\
P\end{array}$ & $\begin{array}{c}-0.16 \\
70.865 \\
0.872 \dagger\end{array}$ \\
\hline Coherence & $\begin{array}{c}N \\
\text { Mean } \\
\text { S.D. }\end{array}$ & $\begin{array}{c}40 \\
3.450 \\
0.959\end{array}$ & $\begin{array}{l}40 \\
3.231 \\
1.245\end{array}$ & $\begin{array}{c}\mathrm{T} \\
\mathrm{df} \\
\mathrm{P}\end{array}$ & $\begin{array}{c}0.88 \\
71.41 \\
0.385\end{array}$ \\
\hline
\end{tabular}

Note: $\dagger=F$ test of equal variances rejected at alpha of .05

Responses to the questionnaires reveal that although the essay possesses a traditional Japanese essay style, some American subjects, particularly instructors, considered it to be similar to an English essay. One instructor, for example, commented:

Very similar. My only criticism is with the word "art" in the last two paragraphs. If I change that to the word "literature," his/her point becomes much clearer. A very interesting and analytical essay. 
In addition, contrary to Sample A, many found this essay to be coherent and to have good transitions. Only a few indicated transition and coherence problems other than in the ten part, the third paragraph.

A change of topic in ten was noticed by some readers, although it is not so abrupt as one that often appears in many Japanese essays. Some of them considered it to be a break in transition and in the development of the idea. One student remarked:

The second page begins to talk about art, and it had not been mentioned before, had it? To me, art does not capture and show me parts of my life experiences. I really don't have much art in my life, but I do have many different types of books. I would like the story to end on line 40 [at the end of the sho part]!

The differences observed by American readers include the characteristics mentioned by Kaplan (1966), such as repetition of the same word or the same idea, and circular development of the idea. One student noted:

There exists an almost circular, introspective, vagueness that one does not often find in English composition.

These characteristics were mainly found in the second paragraph, sho, which is unconventionally longer than one in ordinary Japanese essays with a ki-sho-ten-ketsu pattern. 
Some subjects pointed out that the introduction and the conclusion were different from what was expected in an English essay. Following are the observations by two of the students:

There is not a distinct introduction with a clear statement of the writer's purpose (thesis) in an explicit sense. It is mentioned -- alluded to -- almost as an after thought, and very indirectly near the end. There is no conclusion, as ordinarily seen in written English summarizing the essay.

The thesis statement does not occur until the next to the last paragraph. What should be the introductory paragraph comes right before the concluding paragraph.

Although this sample received considerably high evaluation from many American subjects, especially instructors, there were a few who claimed difficulty in understanding this writing sample. One of them stated:

For me, this was the most difficult essay to understand, and the one which overall seems to me to be most different from what a native speaker of English would produce. The last two paragraphs do not relate well. The rest of the article made sense, but was not on a topic that an English speaker would write about.

The difficulty experienced by some readers could be explained partly in terms of the differences in writing discussed above, and partly in terms of metaphorical treatment of the topic, which was regarded as a characteristic of "Oriental writing" by one of the 
subjects. Such variances observed by the American subjects resulted in the large standard deviations for that group of subjects.

Some Japanese subjects provided comments on this sample. They remarked that the essay was verbous and long-winded especially the first two paragraphs. In addition, one of the Japanese instructors commented that although this essay was interesting and sophisticated, it was largely dependent on the readers' understanding of the topic. This comment can be interpreted as suggesting that readers are required to possess a deep level of assumed background knowledge to understand the author's argument. These comments could explain some of the reasons for the Japanese instructors' comparatively low evaluation.

\section{Sample C}

This writing sample apparently provides only specific information without an obvious general statement either explicit or implicit. The first three paragraphs report the visit of a group of Sioux children to the Ainu, the aboriginal race living in Hokkaido, Japan. The information about the Sioux tribe and the children visiting the Ainu is then provided in the fourth paragraph. The importance of exchanges among aboriginal minorities is mentioned in paragraph five referring to the words stated by the organizer of this visit. The next paragraph discusses the plight of American Indians. The last two paragraphs introduce a different group of Indians who are currently visiting in Japan. The last paragraph is one sentence long. 
As Tables XXIII and XXIV show, neither instructors nor students demonstrated significant differences in the total scores and the holistic evaluations between the two countries. However, an F$\max$ test indicated that the variances among American students were significantly larger than those among Japanese students, as can be shown in the values of the standard deviations. Among the evaluation categories, the two groups of instructors demonstrated significant differences only in coherence with a p-value of 0.021 .

\section{TABLE XXIII}

INSTRUCTORS: SAMPLE C COMPARISON OF EVALUATIONS

\begin{tabular}{|c|c|c|c|c|c|}
\hline & & Japan & the U.S. & Separate & Variances \\
\hline Total & $\begin{array}{c}\mathrm{N} \\
\text { Mean } \\
\text { SD. }\end{array}$ & $\begin{array}{c}20 \\
12.000 \\
3.434\end{array}$ & $\begin{array}{c}20 \\
9.975 \\
4.709\end{array}$ & $\begin{array}{c}T \\
\mathrm{df} \\
P\end{array}$ & $\begin{array}{c}1.55 \\
34.75 \\
0.129\end{array}$ \\
\hline Hol Ev. & $\begin{array}{c}\mathrm{N} \\
\text { Mean } \\
\text { S.D. }\end{array}$ & $\begin{array}{c}20 \\
2.850 \\
0.933\end{array}$ & $\begin{array}{c}20 \\
2.475 \\
1.186\end{array}$ & $\begin{array}{c}T \\
d f \\
P\end{array}$ & $\begin{array}{c}1.11 \\
36.01 \\
0.274\end{array}$ \\
\hline Unity & $\begin{array}{c}\mathrm{N} \\
\text { Mean } \\
\text { SD. }\end{array}$ & $\begin{array}{c}20 \\
2.950 \\
1.050\end{array}$ & $\begin{array}{c}20 \\
2.650 \\
1.424\end{array}$ & $\begin{array}{c}T \\
d \mathbf{f} \\
P\end{array}$ & $\begin{array}{c}0.76 \\
34.94 \\
0.453\end{array}$ \\
\hline Focus & $\begin{array}{c}\mathrm{N} \\
\text { Mean } \\
\text { S.D. }\end{array}$ & $\begin{array}{c}20 \\
3.100 \\
1.021\end{array}$ & $\begin{array}{c}20 \\
2.550 \\
1.234\end{array}$ & $\begin{array}{c}\mathrm{T} \\
\mathrm{df} \\
\mathrm{P}\end{array}$ & $\begin{array}{c}1.54 \\
36.71 \\
0.133\end{array}$ \\
\hline Coherence & $\begin{array}{c}\mathrm{N} \\
\text { Mean } \\
\text { S.D. }\end{array}$ & $\begin{array}{c}20 \\
3.100 \\
0.968\end{array}$ & $\begin{array}{c}20 \\
2.300 \\
1.129\end{array}$ & $\begin{array}{c}T \\
d f \\
P\end{array}$ & $\begin{array}{c}2.41 \\
37.14 \\
0.021 *\end{array}$ \\
\hline
\end{tabular}


TABLE XXIV

STUDENTS: SAMPLE C COMPARISON OF EVALUATIONS

\begin{tabular}{|c|c|c|c|c|c|}
\hline & & Japan & the U.S. & Separate & Variances \\
\hline Total & $\begin{array}{c}\mathrm{N} \\
\text { Mean } \\
\text { SD. }\end{array}$ & $\begin{array}{c}40 \\
12.050 \\
3.297\end{array}$ & $\begin{array}{c}39 \\
11.900 \\
5.007\end{array}$ & $\begin{array}{c}T \\
\mathrm{df} \\
P\end{array}$ & $\begin{array}{c}0.16 \\
67.47 \\
0.875 \dagger\end{array}$ \\
\hline Hol Ev. & $\begin{array}{c}\mathrm{N} \\
\text { Mean } \\
\text { S.D. }\end{array}$ & $\begin{array}{c}40 \\
2.975 \\
0.947\end{array}$ & $\begin{array}{c}40 \\
2.975 \\
1.165\end{array}$ & $\begin{array}{c}T \\
d f \\
P\end{array}$ & $\begin{array}{c}0.00 \\
74.86 \\
1.000\end{array}$ \\
\hline Unity & $\begin{array}{c}\mathrm{N} \\
\text { Mean } \\
\text { SD. }\end{array}$ & $\begin{array}{c}40 \\
3.175 \\
0.874\end{array}$ & $\begin{array}{c}40 \\
3.100 \\
1.336\end{array}$ & $\begin{array}{c}T \\
d f \\
P\end{array}$ & $\begin{array}{c}0.30 \\
67.21 \\
0.767 \dagger\end{array}$ \\
\hline Focus & $\begin{array}{c}\text { N } \\
\text { Mean } \\
\text { S.D. }\end{array}$ & $\begin{array}{c}40 \\
2.925 \\
0.891\end{array}$ & $\begin{array}{c}40 \\
3.050 \\
1.413\end{array}$ & $\begin{array}{c}T \\
d f \\
P\end{array}$ & $\begin{array}{l}-0.47 \\
68.03 \\
0.643 \dagger\end{array}$ \\
\hline Coherence & $\begin{array}{c}N \\
\text { Mean } \\
\text { S.D. }\end{array}$ & $\begin{array}{c}40 \\
2.975 \\
0.891\end{array}$ & $\begin{array}{c}40 \\
2.775 \\
1.349\end{array}$ & $\begin{array}{c}\mathrm{T} \\
\mathrm{df} \\
\mathrm{P}\end{array}$ & $\begin{array}{c}0.78 \\
67.59 \\
0.437 \dagger\end{array}$ \\
\hline
\end{tabular}

Note: $\dagger=F$ test of equal variances rejected at alpha of .05

Responding to the questionnaires, many American subjects remarked that this sample lacked focus and transition both on the intra- and inter-paragraph levels, suggesting that it was similar to an unskilled native speaker's composition. One of the American instructors commented:

This seems like a beginning student's work, an unskilled English writer, afraid that s/he doesn't have enough to say, who puts down a topic and free associates about it. 
The writer is unable to focus on the significance of the visit, but gets distracted into side issues. It's interesting to mention these issues, but they should be balanced, subordinated to larger questions.

Some observed that paragraph four and the last two paragraphs digressed from the topic.

Some students pointed out that the sample has a different paragraph order from an ordinary English composition and suggested more appropriate orders in English writing. Their suggestions included grouping of information that was related and a chronological rearrangement of ideas. In Japanese writing, because a change of viewpoint is valued, as seen in the traditional ki-sho-tenketsu pattern, the arrangement of information that seems to be disconnected in English writing could be effective in Japanese writing.

Differences were also noticed in the introduction and the conclusion. Many observed the introduction of a new idea in the last two paragraphs and a lack of a conclusion in the sense of English writing. One of the students stated:

There's no statement of purpose and then details following. The most important idea is buried in paragraph 6. Also, the last sentence is out of place. It's an unimportant detail given a prominent position.

Although this essay received the lowest evaluation of the six on average, some American subjects graded it highly, which resulted in the large value of the standard deviations. Responding to the 
questionnaire, these subjects remarked that the sample was very similar to a newspaper article written for high school students. On the other hand, the Japanese subjects considered this sample to be an essay, although some of them recognized short journalistic sentence structures and paragraph structures. This divergence in views resulted from the thesis being buried under the surface, or an omission of the thesis statement in Kobayashi's classification (1984).

The following comment by one of the students aptly summarizes the differences observed by American subjects:

No apparent introduction and explicit statement of thesis.

No conclusion which summarizes the essay. There is much interesting information presented in what -- from a written English perspective -- is presented in a very disjointed or diffuse manner. Much of it would appear to be unrelated to a supposed central idea, although it does convey useful information.

Samples D, E, and F were evaluated only by students or their equivalents in both Japan and the United States.

\section{Sample D}

The central topic of Sample D, which is the overcrowding of space with satellites and its consequent problems, is first introduced in the third paragraph. The first paragraph starts by describing the pleasure of looking at the sky, and then the topic changes to the night sky, stars, and finally to satellites in the second paragraph. The fourth to sixth paragraphs discuss the problems of the overcrowding 
of satellites. The essay is again ended with a one-sentence conclusion.

The evaluations of the two subject groups demonstrated no significant differences as can be shown in Table XXV. However, the American subjects evaluated the sample more highly than the Japanese subjects in every category, and the variances among the American subjects were significantly larger than those among the Japanese subjects.

\section{TABLE XXV}

\section{STUDENTS: SAMPLE D COMPARISON OF EVALUATIONS}

\begin{tabular}{|c|c|c|c|c|c|}
\hline & & Japan & the U.S. & Separate & Variances \\
\hline \multirow{3}{*}{ Total } & $\mathrm{N}$ & 40 & 39 & $\mathrm{~T}$ & -1.08 \\
\hline & Mean & 13.250 & 14.125 & $\mathrm{df}$ & 72.93 \\
\hline & S.D. & 3.103 & 4.065 & $P$ & $0.283 \dagger$ \\
\hline \multirow[t]{3}{*}{ Hol Ev. } & $\mathrm{N}$ & 40 & 40 & $\mathrm{~T}$ & -1.44 \\
\hline & Mean & 3.275 & 3.575 & $\mathrm{df}$ & 73.98 \\
\hline & S.D. & 0.816 & 1.035 & $P$ & 0.154 \\
\hline \multirow{3}{*}{ Unity } & $\mathrm{N}$ & 40 & 40 & $\mathrm{~T}$ & -0.70 \\
\hline & Mean & 3.400 & 3.550 & $\mathrm{df}$ & 74.15 \\
\hline & S.D. & 0.841 & 1.061 & $P$ & 0.486 \\
\hline \multirow[t]{3}{*}{ Focus } & $\mathrm{N}$ & 40 & 40 & $\mathrm{~T}$ & -0.95 \\
\hline & Mean & 3.350 & 3.575 & $\mathrm{df}$ & 76.37 \\
\hline & S.D. & 0.975 & 1.130 & $\mathrm{P}$ & 0.343 \\
\hline \multirow[t]{3}{*}{ Coherence } & $\mathrm{N}$ & 40 & 40 & $\mathrm{~T}$ & -0.87 \\
\hline & Mean & 3.225 & 3.425 & $\mathrm{df}$ & 69.57 \\
\hline & S.D. & 0.832 & 1.196 & $P$ & $0.388 \dagger$ \\
\hline
\end{tabular}

Note: $\dagger=\mathrm{F}$ test of equal variances rejected at alpha of .05 
The American students bestowed the second highest evaluation on this sample. Reflecting the high evaluation, many respondents observed good transitions and coherence in the essay; some viewed the essay as similar to an English essay. One student remarked that s/he thought it had been written by a native speaker.

However, differences were also observed at several points. Among those who noticed good transitions and coherence, some felt that although these transitions were good, the essay lacked unity. One of the students commented:

This essay is interesting because it does a very good job of using transitions to tie together a lot of (what appear to be) unrelated paragraphs. The parts are stuck together (coherence), but have no commonality (no unity).

Pertaining to this, some observed switching of topics within and between paragraphs. One of them described the topic change as follows:

The whole essay seems with the first paragraph and second to be talking about the beauty of the sky, but suddenly shifts to some bad things about the sky and space.

The topic change recognized, perhaps negatively, by American readers in the first two paragraphs can be interpreted differently from a Japanese point of view. As discussed by Tokoro (1986), the introduction of this essay is not the introduction of a Western 
"introduction-body-conclusion" essay but the gradual opening of the traditional Japanese rhetorical pattern, jo-ha-kyu. Japanese readers would not have difficulty in reaching the central topic of the essay.

Some felt that paragraphing in this sample was also different. In addition to a lack of unity within paragraphs, some commented on paragraph boundaries. One of them remarked:

Paragraph breaks seem to come in unusual places. I get the impression that what seems like transition between paragraphs should actually be part of the previous paragraph, leaving fewer smooth transitions.

Differences were also observed in the conclusion. It was considered to be implicit, unclear, and abrupt by some.

\section{Sample E}

The topic of Sample E is the U.S. Navy's shooting down of an Iranian commercial airplane. The essay begins with an anecdote of New York policemen to introduce the concept of a "shoot before you get shot" mentality. In the second paragraph, the topic of the essay is introduced, and the anecdote in the first paragraph is related to the topic in the latter half of the paragraph. The third paragraph provides information about the casualties. In the next two paragraphs, legitimacy of the shooting is questioned. The author concludes the essay by stating precautions against the possibility of this incident triggering a larger tragedy, by referring to World War I and to the Sino-Japanese war. 
TABLE XXVI

STUDENTS: SAMPLE E COMPARISON OF EVALUATIONS

\begin{tabular}{|c|c|c|c|c|c|}
\hline & & Japan & the U.S. & Separate & Variances \\
\hline Total & $\begin{array}{c}\mathrm{N} \\
\text { Mean } \\
\text { S.D. }\end{array}$ & $\begin{array}{c}40 \\
15.375 \\
3.135\end{array}$ & $\begin{array}{c}19 \\
13.632 \\
3.890\end{array}$ & $\begin{array}{c}\mathrm{T} \\
\mathrm{df} \\
\mathrm{P}\end{array}$ & $\begin{array}{c}1.71 \\
29.52 \\
0.098\end{array}$ \\
\hline Hol Ev. & $\begin{array}{c}\mathrm{N} \\
\text { Mean } \\
\text { S.D. }\end{array}$ & $\begin{array}{c}40 \\
3.875 \\
0.853\end{array}$ & $\begin{array}{c}19 \\
3.474 \\
0.905\end{array}$ & $\begin{array}{c}\mathrm{T} \\
\mathrm{d} f \\
\mathrm{P}\end{array}$ & $\begin{array}{c}1.62 \\
33.64 \\
0.114\end{array}$ \\
\hline Unity & $\begin{array}{c}\mathrm{N} \\
\text { Mean } \\
\text { S.D. }\end{array}$ & $\begin{array}{c}40 \\
3.800 \\
0.823\end{array}$ & $\begin{array}{c}20 \\
3.500 \\
1.235\end{array}$ & $\begin{array}{c}\mathrm{T} \\
\mathrm{d} f \\
\mathrm{P}\end{array}$ & $\begin{array}{c}0.98 \\
27.70 \\
0.334 t\end{array}$ \\
\hline Focus & $\begin{array}{c}\mathrm{N} \\
\text { Mean } \\
\text { S.D. }\end{array}$ & $\begin{array}{c}40 \\
3.850 \\
0.921\end{array}$ & $\begin{array}{c}20 \\
3.150 \\
0.988\end{array}$ & $\begin{array}{c}T \\
d f \\
P\end{array}$ & $\begin{array}{c}2.65 \\
35.81 \\
0.012 *\end{array}$ \\
\hline Coherence & $\begin{array}{c}\mathrm{N} \\
\text { Mean } \\
\text { SD. }\end{array}$ & $\begin{array}{c}40 \\
3.850 \\
0.893\end{array}$ & $\begin{array}{c}20 \\
3.450 \\
1.050\end{array}$ & $\begin{array}{c}T \\
d f \\
P\end{array}$ & $\begin{array}{c}1.46 \\
33.12 \\
0.1537\end{array}$ \\
\hline
\end{tabular}

Note: $*$ significant at alpha of .05

$\dagger=F$ test of equal variances rejected at alpha of .05

Only twenty American subjects evaluated Sample E. The evaluations for Sample $E$ were not significantly different between the two countries in either total scores or holistic evaluation. However, as Table XXVI demonstrates, a tendency toward significance was observed. Among evaluation categories, the two groups of subjects demonstrated significant differences only for focus with a p-value of 0.012 , and an F-max test showed that variances among the American 
subjects were significantly larger for unity than those among the Japanese subjects.

Sample E received a high evaluation by both American subjects and Japanese subjects. Japanese subjects, especially, evaluated it the second highest of the six samples.

Responses to the questionnaires indicated that the intraparagaraph level of the essay was perceived to be not so different from English writing except in grammar and some phrasing. American subjects offered comments such as "no real difference," "nicely blocked information," and "each paragraph is welldeveloped."

Contrary to the intra-paragraph level, American readers found that either the introduction or the conclusion did not closely relate to the other parts of the essay. One of the students, for example, viewed the introduction as follows:

The first paragraph sets a theme that isn't continued, really.

In the introduction, the author discusses the "shoot before you get shot" mentality; he analyzes the cause of the shootdown of the Iranian airliner in terms of this mentality. However, he does not return to the theme again.

More students pointed out that the conclusion did not complete the essay well. One of them observed: 
If the last paragraph is really the "moral" or conclusion of this essay, there has been no supporting evidence given for it in the paragraphs above. The article talks about the "shoot before you get shot" mentality, but the last paragraph talks about shots that start wars, two different things.

For Japanese readers, the topics that were newly introduced in the last paragraph, World War I and Sino-Japanese war, were both related to the war that could break out if the shooting incident were not solved with great care. For most Japanese readers, this indirect and implicit conclusion would be more effective than direct criticism of the U.S. action, leaving them room for connecting the topics themselves, and for further consideration of war in general.

\section{Sample F}

In the first two paragraphs of Sample $F$, the author talks about a change of season by means of swallows' flying to the south. Since the Japanese are especially sensitive to changes in nature according to the seasons, migratory birds are often referred to both in writing and in speech at a turning point of the seasons. The author gradually moves to the main topic in the third paragraph, that is, how migratory birds can know the season and the direction of their migration. The next three paragraphs examine this question, referring to the scientific studies. The last paragraph comes back to the topic of a change of season. The use of the past tense in the last sentence indicates that summer is over.

The evaluation for Sample $F$ was considerably similar between the two countries. Table XXVII demonstrates no significant 
differences either in total scores or in holistic evaluation. However, large variances among American subjects for total scores were noticeable. The other evaluation categories did not demonstrate significant differences, either. Large variances among American subjects were observed for unity and coherence.

TABLE XXVII

STUDENTS: SAMPLE F COMPARISON OF EVALUATIONS

\begin{tabular}{|c|c|c|c|c|c|}
\hline & & Japan & the U.S. & Separate & Variances \\
\hline Total & $\begin{array}{c}N \\
\text { Mean } \\
\text { S.D. }\end{array}$ & $\begin{array}{c}40 \\
12.575 \\
3.396\end{array}$ & $\begin{array}{c}40 \\
12.488 \\
4.601\end{array}$ & $\begin{array}{l}T \\
d f \\
P\end{array}$ & $\begin{array}{c}0.10 \\
71.76 \\
0.923 \dagger\end{array}$ \\
\hline Hol Ev. & $\begin{array}{c}\mathrm{N} \\
\text { Mean } \\
\text { S.D. }\end{array}$ & $\begin{array}{c}40 \\
3.125 \\
0.939\end{array}$ & $\begin{array}{c}40 \\
3.138 \\
1.149\end{array}$ & $\begin{array}{c}\mathrm{T} \\
\mathrm{df} \\
\mathrm{P}\end{array}$ & $\begin{array}{l}-0.05 \\
75.02 \\
0.958\end{array}$ \\
\hline Unity & $\begin{array}{c}\mathrm{N} \\
\text { Mean } \\
\text { S.D. }\end{array}$ & $\begin{array}{c}40 \\
3.225 \\
0.862\end{array}$ & $\begin{array}{c}40 \\
3.175 \\
1.318\end{array}$ & $\begin{array}{c}\mathrm{T} \\
\mathrm{df} \\
\mathrm{P}\end{array}$ & $\begin{array}{c}0.20 \\
67.19 \\
0.842 \dagger\end{array}$ \\
\hline Focus & $\begin{array}{c}\mathrm{N} \\
\text { Mean } \\
\text { S.D. }\end{array}$ & $\begin{array}{c}40 \\
2.875 \\
1.017\end{array}$ & $\begin{array}{c}40 \\
3.150 \\
1.252\end{array}$ & $\begin{array}{c}\mathrm{T} \\
\mathrm{df} \\
\mathrm{P}\end{array}$ & $\begin{array}{l}-1.08 \\
74.88 \\
0.284\end{array}$ \\
\hline Coherence & $\begin{array}{c}\mathrm{N} \\
\text { Mean } \\
\text { S.D. }\end{array}$ & $\begin{array}{c}40 \\
3.350 \\
0.834\end{array}$ & $\begin{array}{c}40 \\
3.025 \\
1.310\end{array}$ & $\begin{array}{c}T \\
\mathrm{df} \\
\mathrm{P}\end{array}$ & $\begin{array}{c}1.32 \\
66.12 \\
0.190 \dagger\end{array}$ \\
\hline
\end{tabular}

Note: $\dagger=\mathrm{F}$ test of equal variances rejected at alpha of .05 
In their responses to the questionnaires, some American students pointed out that the essay lacked unity without a clear purpose within paragraphs. One of them remarked:

A lot of different ideas in each paragraph. It seems almost stream of consciousness.

Another stated that only specific examples were included without a general statement. The unexpected mixture of a scientific tone with a poetic tone was also pointed out.

Some subjects considered the use of first person subject " $\mathrm{I}$ " in the essay to be too informal for academic papers. This is the problem Japanese speakers often encounter when they write in English. When they write in Japanese, the first person subject "I" is deleted in most cases and the sentences acquire some neutral nature. Hedges such as "I think," "I feel," "I suppose" are often observed in Japanese speakers' composition in English; the subject "I" in the hedges is, however, usually deleted in Japanese, and their function is to avoid too direct and strong expression. As a subject is always required in English, a neutral "I" in Japanese becomes a subjective "I" in English. Although "I" appears five times in the English translation of this sample, it never appears in the Japanese original.

On the inter-paragraph level of the essay, many American students mentioned the unexpected introduction of new information in the last paragraph. Reference to the new information without any further development surprised them. One of them stated: 
Paragraph seven introduces a totally new point of consideration (food) which could probably be worked into the article if it were developed and used as one of several other factors involved in bird migration. However, as it is, it is unrelated and is certainly not a fitting conclusion.

In paragraph seven, the last paragraph, the author relates the text information to his own experience according to Kobayashi's classification of general statements (1984) discussed in chapter II. The first sentence in the paragraph is an author's sympathetic consideration on migratory birds; however, it also functions as a transition from scientific discussion of migratory birds to the topic of the change of seasons in the last sentence. The author returns to the topic of the first two paragraphs at the very end of the essay.

Some students argued that the ending paragraph was too abrupt and incomplete for English writing. One of them remarked:

Though the transitions are smooth, I feel like I missed the point when I get to the end. There is a shift of focus at the beginning of paragraph five. The last paragraph does not seem to belong. I wonder, when I have finished reading, what message I was supposed to get, I feel the piece is connected but lacks conclusion and resolution.

Another student commented, "the ending left me in the air waiting for more." The conclusion of this writing sample appears to be very different from what most native English speakers expect for English composition. 


\section{Sample E and its Revision, Sample E2}

Sample E was revised so that the main topic of the essay might be introduced at the beginning of the essay and the information on the same subtopic might be grouped. In the revision, Sample E2, the shooting down of an Iranian airplane by the U.S. Navy is introduced in the first paragraph, and the story of a New York policeman is grouped into the second paragraph, explaining the cause of the U.S. Navy shooting. The other three paragraphs are the same as in Sample E. The third and the fourth paragraphs present an argument against the legitimacy of the U.S. action. In the last paragraph, the author offers warnings against the further development of the incident, referring to the two disastrous world wars in the past.

Contrary to the presupposition, the original essay, Sample E, received higher evaluation for total scores and holistic evaluation than the revised text, Sample E2, as can be seen in Table XXVIII. Although the results were not significant, a tendency toward differences between two samples was observed in total scores and holistic evaluations with, respectively, a p-value of 0.080 and 0.078 . The results of each evaluation category demonstrated a similar tendency. Only the evaluation of coherence was significantly different between the two samples with a p-value of 0.016 ; that is Sample E received significantly higher evaluation for coherence than Sample E2. 
TABLE XXVIII

\section{AMERICAN STUDENTS: SAMPLE E AND SAMPLE E2}

\begin{tabular}{|c|c|c|c|c|c|}
\hline & & Sample E & Sample E2 & Separate & Variances \\
\hline Total & $\begin{array}{c}\mathrm{N} \\
\text { Mean } \\
\text { S.D. }\end{array}$ & $\begin{array}{c}19 \\
13.632 \\
3.890\end{array}$ & $\begin{array}{c}20 \\
11.075 \\
4.926\end{array}$ & $\begin{array}{l}T \\
d f \\
P\end{array}$ & $\begin{array}{c}1.80 \\
35.83 \\
0.080\end{array}$ \\
\hline Hol Ev. & $\begin{array}{c}\mathrm{N} \\
\text { Mean } \\
\text { S.D. }\end{array}$ & $\begin{array}{c}19 \\
3.474 \\
0.905\end{array}$ & $\begin{array}{c}20 \\
2.850 \\
1.226\end{array}$ & $\begin{array}{c}T \\
d f \\
P\end{array}$ & $\begin{array}{c}1.81 \\
34.92 \\
0.078\end{array}$ \\
\hline Unity & $\begin{array}{c}\mathrm{N} \\
\text { Mean } \\
\text { S.D. }\end{array}$ & $\begin{array}{c}20 \\
3.500 \\
1.235\end{array}$ & $\begin{array}{c}20 \\
2.950 \\
1.356\end{array}$ & $\begin{array}{l}T \\
d f \\
P\end{array}$ & $\begin{array}{c}1.34 \\
37.67 \\
0.188\end{array}$ \\
\hline Focus & $\begin{array}{c}\mathrm{N} \\
\text { Mean } \\
\text { S.D. }\end{array}$ & $\begin{array}{c}20 \\
3.150 \\
0.988\end{array}$ & $\begin{array}{c}20 \\
2.700 \\
1.455\end{array}$ & $\begin{array}{c}T \\
\mathrm{df} \\
P\end{array}$ & $\begin{array}{c}1.14 \\
33.46 \\
0.261 \dagger\end{array}$ \\
\hline Coherence & $\begin{array}{c}\mathrm{N} \\
\text { Mean } \\
\text { S.D. }\end{array}$ & $\begin{array}{c}20 \\
3.450 \\
1.050\end{array}$ & $\begin{array}{c}20 \\
2.575 \\
1.139\end{array}$ & $\begin{array}{l}T \\
d f \\
P\end{array}$ & $\begin{array}{l}2.53 \\
37.75 \\
0.016^{*} \dagger\end{array}$ \\
\hline
\end{tabular}

Note: ${ }^{*}=$ significant at alpha of .05

$\dagger=\mathrm{F}$ test of equal variances rejected at alpha of .05

Although the revised text did not receive higher evaluation than the original text, the results still indicate that different organizational patterns influence the evaluation of an essay.

Several reasons can be given for the lack of success of revision of the essay. First of all, the rhetorical pattern in Sample E2 did not become closer to one of the English rhetorical patterns through the revision; the results showed that the mean value of rhetorical 
perception for Sample E was 3.6, while that for E2 was 2.7. This indicates that American subjects perceived that the original text, Sample E, was closer to English composition than the revised text, Sample E2. In addition, the conclusion, which many American subjects pointed out to be different from English writing in the original, had not been changed at all for the revision.

Secondly, the thesis of the essay did not become clear in the revised text. Some American subjects considered the thesis of the essay to be the "shoot before you get shot" mentality, which was placed in the first paragraph in the original text. Since it was moved to the second paragraph for the revision, the thesis became less clear. Furthermore, the topic of the essay was politically too sensitive for American subjects. One of the subjects claimed:

My overall impression is that this is biased, political diatribe and would be more suitable as a speech (inflammatory!) than as an essay.

Perhaps the anecdote in the first paragraph of Sample E was effective in attenuating the criticism toward the United States. However, as Sample E2 began directly with the U.S. action to the Iranian airliner, the composition lost the author's consideration of the sensitive subject and the criticism had become too direct. 


\section{CHAPTER V}

\section{DISCUSSION AND CONCLUSION}

This chapter first presents a summary of the present research, then discusses the three hypotheses by comparing the statistical data with the subjects' responses to the questionnaires. The present research is also compared with other studies on contrastive rhetoric. Finally, implications for teaching and suggestions for further research are offered.

\section{SUMMARY}

Primarily based on Hinds' study (1982a), this study investigated the question whether or not a Japanese style of writing would be evaluated more highly by Japanese readers than by American readers, especially in academic situations.

For the research, six expository writings were selected as writing samples from Japanese publications, and both a Japanese text and an English translation were prepared for each writing sample. The subjects of this study were university instructors and university students or their equivalents in Japan and in the United States. They were asked to evaluate the writing samples on a scale of one to five according to these categories: unity, focus, coherence, and holistic evaluation. 
The conditions attached to the evaluations were slightly different in each country because of differences in the curriculum at universities between the two countries. The American subjects evaluated the writing samples with a supposition that they were compositions for a freshman writing class; while the Japanese university instructors evaluated them assuming that they were written by university students, and the Japanese university graduates assumed that they were compositions written by ordinary, non-professional people.

In addition to evaluation, American subjects responded to the questionnaires on rhetorical differences for each writing sample. They ranked each sample on how different they thought it was from English composition, and added comments on the difference.

The study found that the two groups of subjects generally agreed with each other on the evaluations of the Japanese expository writings. There were no significant differences in the evaluations between the Japanese subjects and the American subjects. However, interaction between the subject groups and the writing samples was observed in the evaluations, suggesting that different subject groups evaluated different essays highly. It was also observed that variances in the evaluations among American subjects were considerably larger than those among Japanese subjects.

In regard to each evaluation category, a tendency toward interaction between the subject groups and the writing samples was observed in the evaluations of coherence and focus. This suggests 
that Japanese readers and American readers have different expectations toward coherence and focus in written discourse.

American subjects' responses to the questionnaires reflect the large variances in their evaluations. Some felt that the writing samples had similar rhetorical patterns to English essays; others, however, thought that they were very different. Many of the American subjects pointed out a lack of coherence or poor transitions. Following are the main differences observed by American subjects:

- Some paragraphs lack topic sentences and include only specific examples.

- General statements are indirect and implicit and placed in the middle or near the end of the essays, or are not stated at all.

- Conclusions are different from ones ordinarily seen in English writing summarizing the essay. They often appear to be abrupt and incomplete for American readers.

- New ideas are often introduced near the end of the essays.

Some American subjects also observed repetition of the same words and ideas, and felt that the use of the first person subject "I" was too informal in an academic paper. 
High correlation between the evaluations and the perception of rhetorical differences suggests that these different characteristics in Japanese writing appear to be valued somewhat negatively in English writing.

\section{HYPOTHESES}

\section{Hypothesis I}

Hypothesis I stated that Japanese readers would evaluate Japanese expository prose written in Japanese significantly higher than American readers would evaluate the same prose translated into English. This hypothesis was not supported by the statistical data. Neither instructors nor students demonstrated significant differences in holistic evaluations between the two countries, although a tendency toward interaction between the subject groups and the writing samples was observed. The evaluations in the other categories demonstrated similar results. Differences were not significant between the two countries; while a tendency toward interaction between the subject groups and the writing samples was observed in the evaluations of coherence and focus.

The results suggest that there was considerable agreement on the evaluations between Japanese readers and American readers. The writing samples that received high evaluations by one group of readers were evaluated highly by the other group of readers, and vice versa. A tendency was observed that the Japanese and the American readers evaluated different writing samples highly and 
expected different properties in coherence and focus. However, it should be noted that there were considerably large variances among American readers in the evaluations.

The results of this study were not consistent with those of Hinds' study (1982a). In his study, Hinds found that Japanese readers evaluated the organizational properties (i.e. unity, focus, and coherence) of Japanese expository writings consistently higher than did American readers. The differences in the evaluations were significant at .05 level. Based on his study, Hinds suggested that an influence of a Japanese traditional ki-sho-ten-ketsu pattern might be responsible for some negative transfer when Japanese speakers write in English.

In this study, however, a writing sample with a traditional $k i$ sho-ten-ketsu pattern was actually evaluated more highly by American instructors than Japanese instructors. This suggests that a $k i$-sho-ten-ketsu pattern itself is not the reason for negative transfer. Closer investigations of the rhetorical properties and on the perception of these properties by native English speakers are necessary to determine the cause of negative transfer. The writing sample with a ki-sho-ten-ketsu pattern in this study has a more linear development of the idea and better coherence in the sense of English composition, but it appears to be too verbose and longwinded to Japanese readers.

Although the present study did not find significant differences in the evaluations between those from Japan and from the United States, it may not be proper to conclude simply that a Japanese style 
of writing is acceptable in American academic situations as it is in Japanese academic situations. Because of differences in curriculum, identical conditions could not be imposed on the research in each country. In Japan, instructors evaluated the writing samples assuming they were written by university students; university graduates assumed they were compositions by ordinary, nonprofessional people. As their evaluations were very similar, it can be argued that their evaluations are compatible. In the United States, both university instructors and students evaluated the writing samples with the supposition that they were written for a freshman writing class. Because the writing done for a freshman writing class appears to be more basic than the present researcher expected, the evaluations in a Japanese university and in an American university may not be exactly compatible.

Therefore, it is proper to conclude that a Japanese style of writing is acceptable as a basic level of composition in American universities as in a similar way it is acceptable as a standard college student's composition in Japanese universities.

\section{Hypothesis II}

Hypothesis II predicted that there would be a positive correlation between the evaluation by American readers and the rhetorical pattern of the composition; in other words, the closer a rhetorical pattern is perceived to be like an English one, the higher the evaluation would be. This hypothesis was supported by statistical data. Both instructors and students demonstrated a high 
positive correlation between their evaluations and their perception of rhetorical differences except for one instance. A high positive correlation was not observed in the instructors' evaluations of the writing sample with a traditional Japanese ki-sho-ten-ketsu pattern.

Although a high positive correlation was observed in most of the writing samples, it is important to investigate the writing sample in which the correlation was not significant. Some American instructors evaluated the writing sample with a ki-sho-ten-ketsu pattern highly even if they did not consider it so similar to an English essay, or vice versa.

In regard to this writing sample, American readers considered the following points as different: the essay had a metaphorical theme; there was a change of topic in the ten part; the thesis statement was implied and appeared at the end of the essay. On the other hand, good transitions and coherence were noticed. Compared to the other writing samples, the essay had a rather linear logical development without a large digression; coherence was less implied and less dependent on readers' background knowledge; a thesis statement was not omitted. These are properties similar to what English readers expect in English writing.

This hypothesis suggests that it is important for non-native speakers to employ English rhetorical patterns when they write in English. However, this is not limited to larger organizational patterns. A finer level of rhetorical properties, such as how writers effectively execute coherence, logical development of idea, and 
general statement in English writing, also seems important in American readers' perception of an essay.

\section{Hypothesis III}

Hypothesis III predicted that if a Japanese text translated into English is revised employing a rhetorical pattern close to one employed in English writing, it will receive significantly higher evaluation by American readers than before revision. This hypothesis was not supported by the statistical data. Perhaps due to a lack of success in the revision, the American readers perceived that the rhetorical pattern of the revised text was less close to an English rhetorical pattern, and evaluated the original text more highly. However, although the revised text did not receive higher evaluation, the results indicate that a change of organizational patterns affects the evaluation of an essay and the perception of its rhetorical differences.

The importance of revision became apparent when the present researcher conducted a pilot study for this part of the research. A writing sample was selected from the essays Hinds (1982a) used in his study, and was revised so that the information on the same subtopic might be grouped. Transition words were also added. Ten subjects evaluated the original text and nine the revised text according to four categories - unity, focus, coherence, holistic impression - on a scale of one to five. The results were that the revised text received considerably higher evaluations than the 
original. (See Appendix $\mathrm{C}$ for the writing samples and the results of the pilot study.)

Revision is an important process of writing. Although organizational change is only a part of revision, it could be effective when organizational patterns are very different. In response to the questionnaires, American subjects pointed out a delayed introduction of a thesis statement, an unclear purpose of the essay, or even a different order of paragraph arrangement. When the original text has such characteristics, organizational changes would be effective in improving the composition.

\section{Questionnaires}

The American subjects' responses to the questionnaires revealed rhetorical differences between Japanese writing and English writing, and confirmed some characteristics of Japanese writing discussed in other studies. Since some of the findings in this research were already discussed in the previous chapter, the discussion in this section focuses on the following two points: differences in coherence and differences in conclusion.

Both the statistical and the verbal data indicated that Japanese readers and American readers have different expectations toward coherence. Japanese readers valued implicit and "dotlike" coherence; while American readers expected explicit and detailed coherence. These differences in expectations led some American readers to consider some of the writing samples as unskilled and poor in coherence. However, as all of the writing samples were selected 
from Japanese publications, and were written by experienced writers, it could be argued that perceived differences are on the rhetorical level, not on the skill level of the writers.

One Japanese graduate student remarked to this author on the differences between Japanese writing and English writing. She said that in Japanese writing, she does not have to tell everything but keeps a certain part of the discourse to herself, but in English writing, if she does not tell every detail or give every connection between the points of her discussion, the reader does not understand her intended meanings.

Toyama (1979) presents a similar discussion by comparing Japanese haiku poetry and Western poetry, referring to an ancient haiku master, Basho. Toyama believes that the essence of haiku is well-described by Basho's remark, "What's the point of explaining everything?" (iiohosete nanika aru); while Western long verse is the literature intending to "explain everything" (iiohoseru) (p. 116). The present researcher feels that differences in coherence between Japanese writing and English writing exist in the differences between "not explaining everything (or withholding)" and "explaining every thing."

Conclusions were also perceived to be very different by many American subjects. What they expected was a conclusion summarizing the essay, while in the writing samples, they found an ending that left them out in the air with a feeling of incompletion. These writing samples ended without concluding the essay but with 
introducing a new idea that had not been developed in the essay and appeared to be unrelated to the other parts of the essay.

Hirai (1972) presents twelve effective ways to end an essay in Japanese writing: 1) restating the theme, 2) leaving suggestiveness, 3) stating personal thought, 4) giving a witty expression, 5) stating a reflection or a self-discipline, 6) using a satire or a criticism, 7) contrasting with the introduction, 8) giving conclusion or summary, 9) stating a writer's requests, 10) citing others' opinion or thought, 11) using a proverb or a well-known saying, 12) posing a question. Most of these methods are largely different from those concluding English essays, only loosely and often very implicitly relating to the other parts of the essay. If new items are introduced in these endings, although they are related to the other parts of the essay in the sense of Japanese writing, or in the formal and the content background knowledge between the Japanese writer and the Japanese readers, they become problematic in English writing, making the essay look unfocused, ununified, and incoherent. One ESL instructor remarked that Japanese students' essays often appear to have two different themes, one of which introduced near the end has not been developed and seems to be a main theme.

Particular attention needs to be paid to coherence and conclusion in order to bridge the differences between the two languages, when Japanese speakers write compositions, especially expository essays, in English. 


\section{PEDAGOGICAL IMPLICATIONS}

The results of the present research, when considered together with the current educational situation in Japan, provides some suggestions for teaching English composition to Japanese speakers.

In Japan, translation is still a main method of teaching English composition. Students learn to translate sentences, sometimes paragraphs, from Japanese to English. The considerable agreement on the evaluation between Japanese and American readers observed in this research indicates that translation could be beneficial in English composition teaching if it is used with good care. Kobayashi and Rinnert (1990) found that low level students derived benefit from translation both in content and style in second language writing, and recommend the use of the first language at an early stage in the writing process, especially for exploring ideas for the low level students.

The responses to the questionnaires reveal the importance of teaching composition on the discourse level. Differences exist in the organizational structures and the rhetorical properties such as coherence, and the Japanese style of writing appears not to be always appropriate in English writing. There are also large variances in its acceptability among American readers. Therefore, it is important to view the composition from the larger level of discourse and teach basic English rhetorical patterns. Perhaps, teaching contrastive rhetoric would be more beneficial for Japanese speakers who study English as a foreign language in order that they 
understand the existing rhetorical differences between the two languages. Carpenter and Hunter (1981) argue:

Our students seemed to benefit from discussing this [the language function from a cross-cultural point of view] for two reasons: first of all, because focusing attention on the patterns of organizing their thoughts beyond the level of the sentence helped create an awareness that such patterns exist in the first place and, secondly, because an approach based on a contrastive philosophy can show students that their customary styles of expressing themselves are not illogical or wrong but are just not the ones appropriate for what they are writing in English (pp. 428-429).

By contrasting the writing in the two different languages, students become more aware of the rhetorical differences and the patterns they should focus on.

To apply the study of the rhetorical differences in teaching and learning composition, revision would become important. Students would first explore and generate their ideas in their first language, and then formulate, develop, and refine those ideas in English. The composition could gradually gain an English rhetorical pattern through several revisions, thereby reducing problematic culturally specific characteristics such as "hedges," and repetitions of the same words and ideas; at the same time, students could develop their ideas more fully. Such a process of writing would reduce the difficulty of transferring an idea that has originated from one logical pattern into another very different and rigid pattern. As students progress in the skills of writing in the second language, teachers should encourage 
them to compose more and more parts directly in the second language, as Kobayashi and Rinnert recommend.

\section{LIMITATIONS OF THE STUDY AND RECOMMENDATIONS FOR FURTHER STUDY}

In the course of this study, several limitations have been experienced. First of all, only six writing samples were used for this study, and the rhetorical patterns employed in them were also limited to those found in some Japanese short expository writings, especially journalistic writings. Therefore, it is not appropriate to generalize comprehensive Japanese rhetorical patterns from the findings of this study. Further investigation of the rhetorical patterns employed in various kinds of writings is needed.

Secondly, problems were also found in the translation. Hinds (1982a) argues that not all Japanese coherence markers are translated into the English text. Besides this issue, this researcher found that the translation of evaluation categories was also difficult. After several attempted translations, the definitions in an EnglishJapanese dictionary were used for the evaluation categories for the research in Japan. However, the original English words and their Japanese translations do not share exactly the same semantic spheres. One Japanese speaker, for example, gave "consistency" for the Japanese word intended as "coherence" in the reverse translation.

The evaluation categories also appear to need improvement. The categories used in one culture are not always appropriate in 
another culture. One Japanese professor of Japanese literature commented that the evaluation categories used in this study were very different from those usually used in Japan. Development of universal evaluation categories is necessary for cross-cultural studies of composition.

For the effective teaching of English composition to Japanese speakers, further study is recommended in contrastive rhetoric and in the influence of Japanese rhetorical patterns on Japanese speakers' composition in English.

Since most of the studies done on contrastive rhetoric between English and Japanese have investigated only expository writing, studies on rhetorical patterns in various other kinds of writing are recommended. Specifically, the study of rhetorical differences in academic papers will be important for teaching English composition in college. Miller (1977) claimed that:

little of what contemporary Japanese scholars write and publish in Japanese could be published intact in a literal English translation without becoming the butt of amazement and even ridicule abroad. Yet these works, which are widely read in Japan, are by eminent men writing in their own fields (p. 2).

Differences in rhetorical patterns also appear to exist in scholarly writing, and this could be most problematic in second language writing.

Another possible area for future research is the influence of teaching English rhetorical patterns on Japanese speakers' 
composition in English, and the process by which they acquire English rhetorical patterns. Although studies of contrastive rhetoric recognize the necessity of teaching English rhetorical patterns, the influences of that instruction have not yet been investigated. As the focus of English teaching shifts from translation to communication in English, such study will be important for effective English composition teaching. 


\section{REFERENCES}

Bailey, N., Madden, C., \& Krashen, S. D. (1974). Is There a "Natural Sequence" in Adult Second Language Learning? Language Learning. 24, 235-243.

Baker, S. (1972). The Complete Stylist. New York: Thomas Y. Crowell Company.

Bander, R. G. (1978). American English Rhetoric. New York: Holt, Rinehalt and Winston.

Becker, A. L. (1965). A Tagmemic Approach to Paragraph Analysis. College Composition and Communication. 16, 237-242.

Braddock, R. (1974). The Frequency and Placement of Topic

Sentences in Expository Prose. Research in Teaching of English. 8, 287-302.

Brown, H. D. (1987). Principles of Language Learning and Teaching. New Jersey: Prentice-Hall, Inc.

Burtoff, M. J. (1983). The Logical Organization of Written Expository Discourse in English: A Comparative Study of Japanese, Arabic, and Native Speaker Strategies. Unpublished Ph.D Dissertation, Georgetown University.

Carpenter, C. \& Hunter, J. (1981). Functional Exercises: Improving Overall Coherence in ESL Writing. TESOL Quarterly. 15:4, 425434

Carrell, P. L. (1986). Text as Interaction: Some Implications of Text Analysis and Reading Research for ESL Composition. Writing Across Languages: Analysis of L2 Text. ed. by Conner, U. \& Kaplan, R.B. Reading, Mass.: Addison-Wesley Publishing Company. 
Christensen, F. (1965). A Generative Rhetoric of the Paragraph. College Composition and Communication. 16, 144-156.

Coe, R. M. (1987). An Apology for Form; or, Who Took the Form Out of the Process? College English. 49, 13-28

Condon, J. C. \& Yousef, F. (1975). An Introduction to Intercultural Communication. New York: The Bobbs-Merill Company, Inc.

Connor, U. (1987). Research Frontiers in Writing Analysis. TESOL Quarterly. 21, 677-696

D'Angelo, F. J. (1974). A Generative Rhetoric of the Essay. College Composition and Communication. 25, 388-396.

Fallows, J. (1987). Gradgrind's Heirs. Atlantic. 259, 16-24.

Grady, M. (1972). On Teaching Christensen Rhetoric. English Journal. $61,859-873,877$.

Hinds, J. (1982a). Contrastive Rhetoric: Japanese and English. Unpublished paper presented at 16 th TESOL Convention in Honolulu.

Hinds, J. (1982b). Linguistics and Written Discourse in English and Japanese: a Contrastive Study (1978-1982). Annual Review of Applied Linguistics. ed. by Kaplan, R. Rowley, Mass: Newbury House Publishers.

Hinds, J. (1983). Contrastive Rhetoric: Japanese and English. Text. 3:2, $183-195$.

Hinds, J. (1987). Reader versus Writer Responsibility: A New Typology. Writing Across Languages: Analysis of L2 Text. Ed. Connor, U. \& Kaplan, R. B. Reading, Massachusetts: AddisonWesley Publishing Company. 141-152.

Hirai, M. (1972). Shinpan, Bunsho o Kaku-gijutsu [Techniques for Composition Writing, New Edition]. Tokyo: Shakai Shisousha Ltd. 
Hughes, R. E. \& Duhamel, P. A. (1962). Rhetoric: Principles and Usage. New Jersey: Prentice Hall, Inc.

Ishii, S. (1982). Thought Patterns as Modes of Rhetoric: The United States and Japan. Intercultural Communication: A Reader 4th ed. 97-102. California: Wadsworth, Inc.

Itasaka, G. (1971). Nihonjin no Ronri-kouzou [Logical Structure of the Japanese]. Tokyo: Kodansha.

Kabashima, T. (1980). Bunsho Kosei-ho [Techniques for Composition]. Tokyo: Kodansha.

Kaplan, R. (1966). Cultural Thought Patterns in Inter-cultural Education. Language Learning, 16; also reprinted in Readings in English as a Second Language, ed. by Kenneth Croft. (1981). 399-418.

Kaplan, R. (1988). Contrastive Rhetoric and Second Language Learning: Notes Toward a Theory of Contrastive Rhetoric. Writing Across Languages and Cultures. ed. by Purves, A. C. 275-304. Beverly Hills: SAGE Publications.

Kaplan, R. (1989). Writing in a Second Language: Contrastive Rhetoric. Richness in Writing: Empowering ESL Students. ed. by Johnson, D. M. \& Roen, D. H. New York: Longman Inc.

Kindaichi, H. (1988). Nihongo [The Japanese Language]. Tokyo: Iwanami-shinsho

Kobayashi, H. (1984). Rhetorical Patterns in English and Japanese. Unpublished Ph. D. Dissertation, Teachers College, Colombia University.

Kobayashi, H. \& Rinnert, C. (1990). Effects of First Language on Second Language Writing: Translation versus Direct Writing. Unpublished paper presented at 24th TESOL convention at San Francisco. 
Liebman-Kleine, J. (1986). Toward a Contrastive New Rhetoric -- A Rhetoric of Process. Unpublished paper presented at the Annual Meeting of the Teachers of English to Speakers of Other Languages in Anaheim, CA.

Lindemann, E. (1987). A Rhetoric For Writing Teachers. New York: Oxford University Press.

Makino, S. (1979). Paragraph, Is It a Legitimate Linguistic Unit? -- A Case Study from English and Japanese. Rhetoric 78. Ed. Brown, R. \& Steinmann, H. Minneapolis, MN: University of Minnesota, Center for Advanced Studies in Language, Style, and Literary Theory. 283-296.

Matalene, C. (1985). Contrastive Rhetoric: An American Writing Teacher in China. College English. 47, 789-808.

Meade, R. A. \& Ellis, W. G. (1970). Paragraph Development in the Modern Age of Rhetoric. English Journal. 59, 219-226.

Miller, R., A. (1977). The Japanese Language in Contemporary Japan. Washington, D. C.: American Enterprise Institute for Public Research.

Mohan, B. A. (1985). Academic Writing and Chinese Students: Transfer and Developmental Factors. TESOL Quarterly. 19:3, $515-534$.

Nakashima, F. (1987). The Structure of Japanese Language. Tokyo: Iwan ami-shinsho

Ogawa, M. (1982). Bunsho no Kakikata [Composition Book]. Tokyo: Kodansha.

Oi, K. M. (1984). Cross-cultural Differences in Rhetorical Patterning: A Study of Japanese and English. Unpublished Ph. D. Dissertation, State University of New York at Atony Brook. 
Okabe, R. (1983). Cultural Assumptions of East and West: Japan and the United States. International and Intercultural Communication Annual. 7, 21-44. Beverly Hills: SAGE Publications, Inc.

Ougiya, S. (1965). Gendaibun no Kakikata [Modern Composition Book]. Tokyo: Kodansha.

Purves, A. C. (1985). On the Nature and Formation of Interpretive and Rhetorical Communities. Highway One. 8:1-2, 79-96.

Purves, A. C. (1986). Rhetorical Communities, the International Student, and Basic Writing. Journal of Basic writing. 5:1, 3851. New York: City University of New York.

Raimes, A. (1985). What Unskilled ESL Students Do as They Write: A Classroom Study of composing. TESOL Quarterly. 19:2, 229-258

Rittershofer, J. S. (1987). The Nominal Reference System in the Interlanguage of Japanese Students Writing in English: A Discourse Analysis. Unpublished Ph.D. Dissertation, Teachers College, Columbia University.

Rodgers, P. C. Jr. 1966. A Discourse-centered Rhetoric of the Paragraph. College Composition and Communication. 17, 2-11.

Rohlen, R. P. (1983). Japan's High Schools. Berkeley: University of California Press, Ltd.

Shimokoube, Y. (1986). Kawabata Yasunari -- Shikaku to Choukaku [Kawabata Yasunari -- Vision and Acoustic Sense]. Kokubungaku [The Japanese Literature] 31:1, 98-101. Tokyo: Gakutousha.

Shiraishi, Y. (1982). Kaisetsu-bun Ronsestu-bun no Bunshou [Expository Writing]. Bunshou Nyuumon. [Introduction to Writing]. co-written by Ishimaru, A., Shiraishi, Y., Tsuge. M., \& Fujii, S. Tokyo: Yuuhikaku Inc. 
Spack, R. (1988). Initiating ESL Students into the Academic Discourse Community: How Far Should We Go? TESOL Quarterly. 22:2, $29-51$.

Stern. A. A. (1976). When Is a Paragraph? College Composition and Communication. Vol.27. pp.253-257.

Tokoro, K. (1986). Nihongo Shikou no Retorikku [Japanese: Rhetoric of Thought]. Tokyo: Takumi Publishing Inc.

Tousu, N. (1987). Bunka no Gengo-gaku [Cultural Linguistics]. Tokyo: Keisoushobou.

Toyama, S. (1976). Nihongo no Kosei [Characteristics of the Japanese Language]. Tokyo: Chuoukoronsha

Toyama, S. (1979). Shoryaku no Bungaku. [The Literature of Omission]. Tokyo: Chuoukoronsha

Wardhaugh,R. (1970). The Contrastive Analysis Hypothesis. TESOL Quarterly. 4:2, 123-30.

Zamel, V. (1982). Writing: The Process of Discovering Meaning. TESOL Quarterly. 16:2, 195-209.

Zamel, V. (1983). The Composing Processes of Advanced ESL Students: Six Case Studies. TESOL Quarterly. 17:2, 165-187. 
APPENDIX A

THE WRITING SAMPLES AND THE EVALUATION SHEETS IN JAPANESE 


\section{ルドルフの涙}

大レースに敗れた本命馬が、きめう捨引き揭けてくるなり。首をうなだれて、两目に

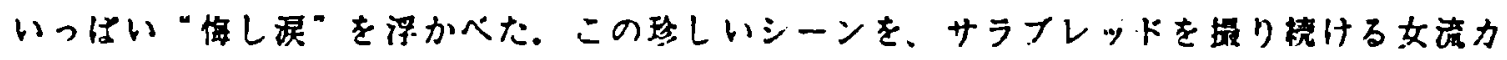

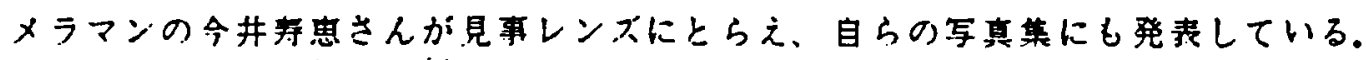

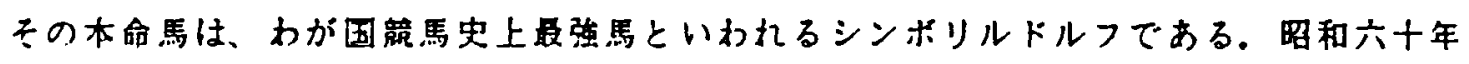

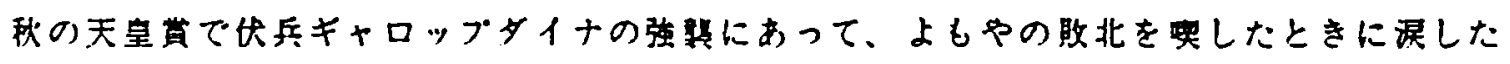
のた.

器争馮はレース中に自にホコリや泥つふてが入ったりすると添を出すことがある。でい

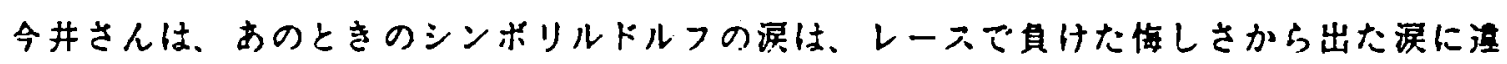
いない、といまでも信している。

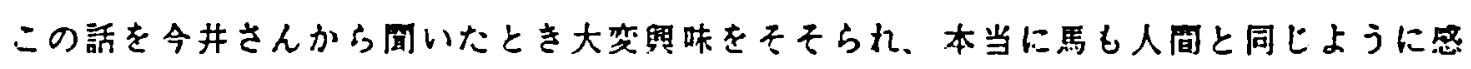

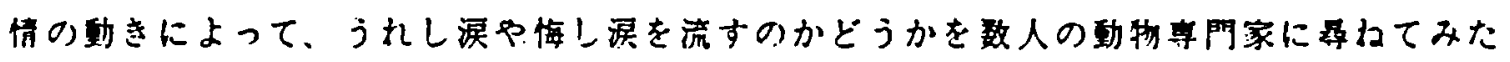
ことがあるはっきりしたことはかからなかったが、馬に感情の展はないだうう、という のがほとんどだった。

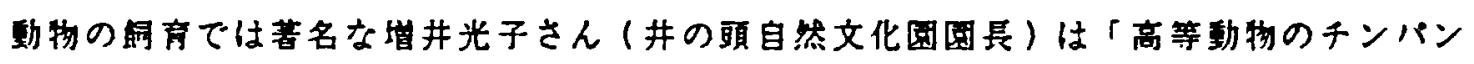

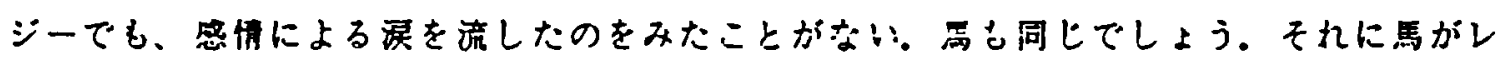
一スの腊ち真什を知っているとも思えない」と否定的である。レースの勝貝については、 世界的な英国の動物学者テスモント・モリス氏も「馬は自分がレースに勝つことを知らな

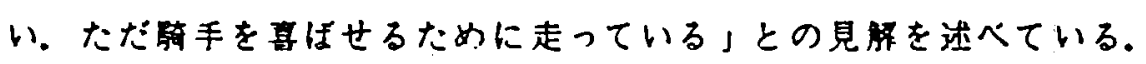

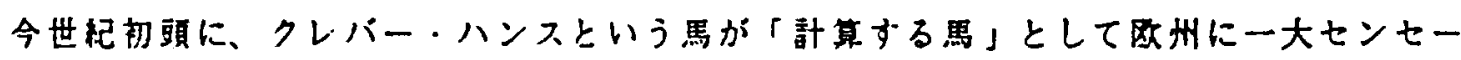

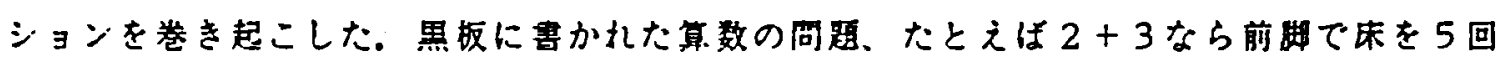
たたくという風にして答え、人を然かせた。どうして計算できたのか。多をあかせは．

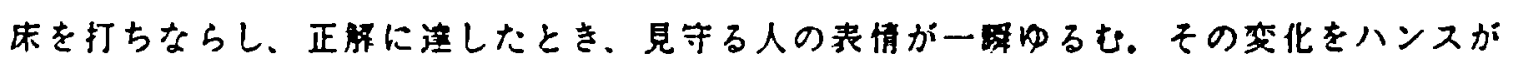
即座に慗知してタッピンクを止めていたのた。

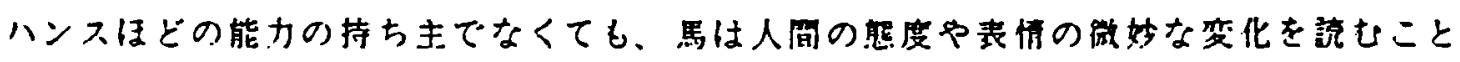

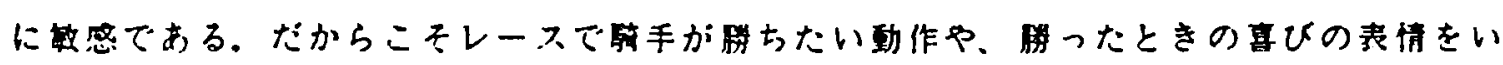

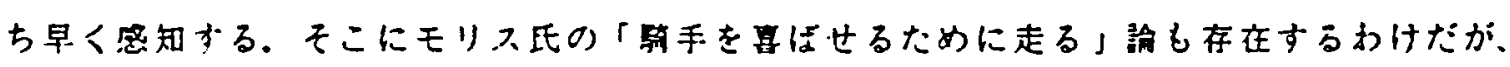

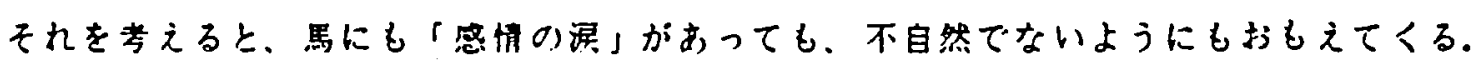




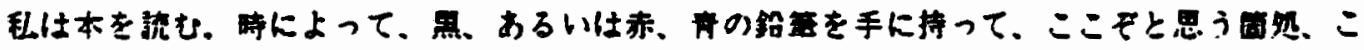

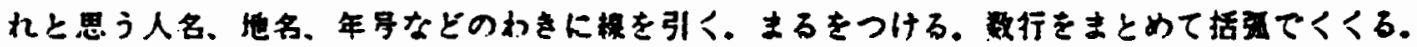

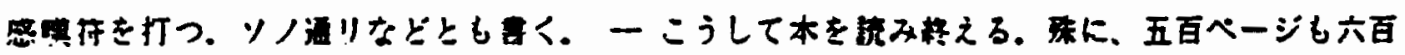

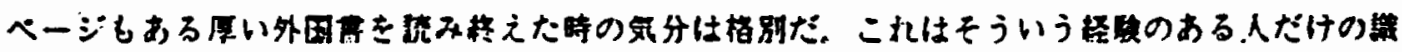

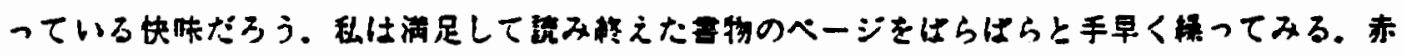

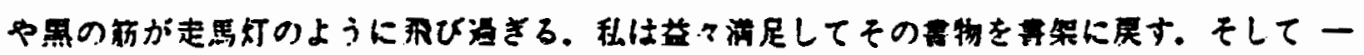

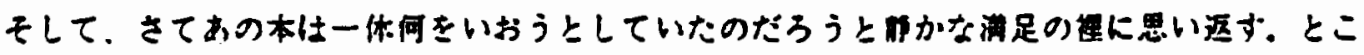

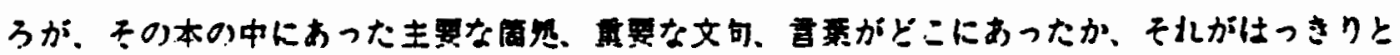

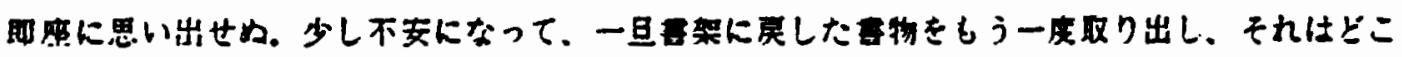

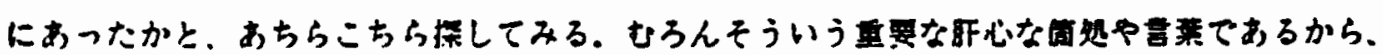

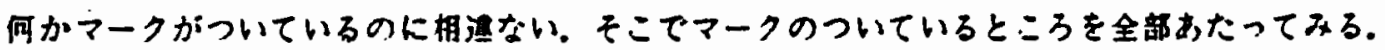

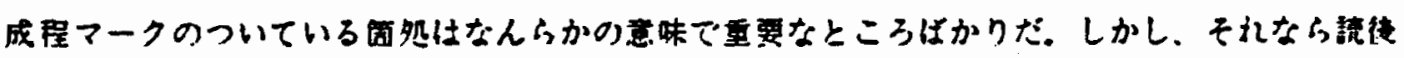

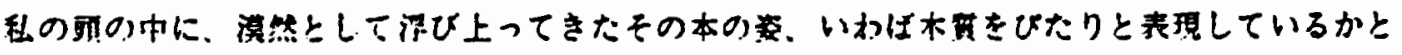
いう上、そうでもないのである。マークきれている然が重要な周然てはないというのではない。

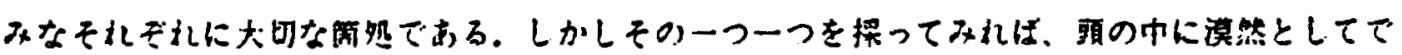

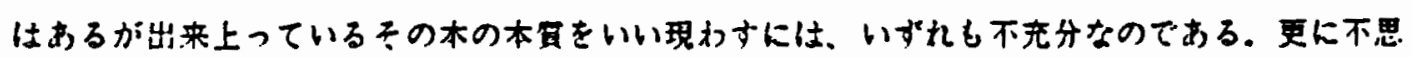

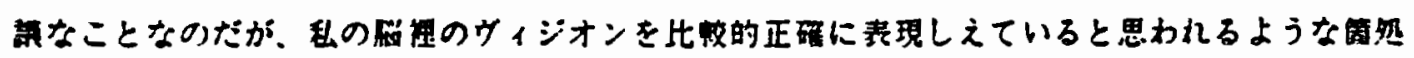

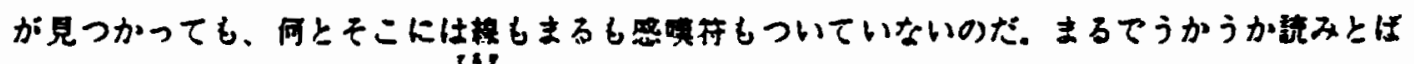

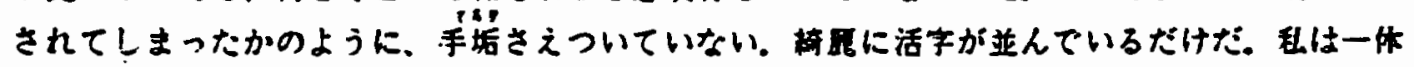

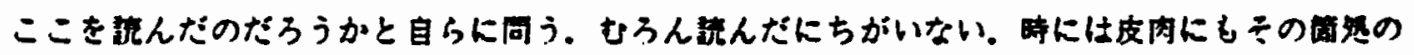
正前の行まではきちんとアンター・ラインが引がていたりする。すると私には、新たに見つけ

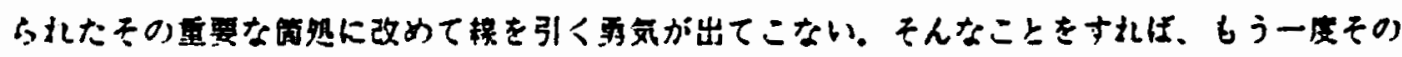

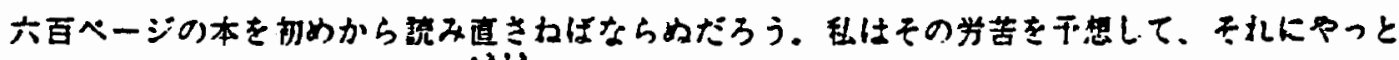

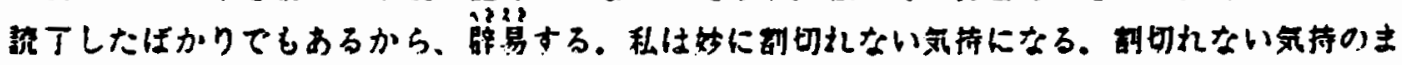

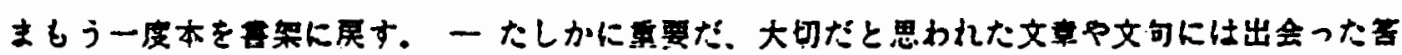

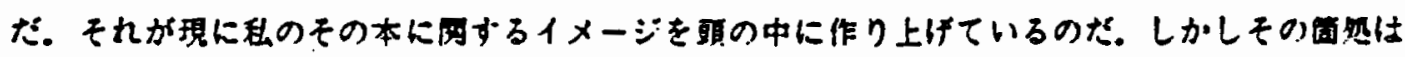

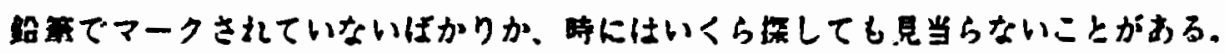

そこで种は、こんなことを考えてしまうのた。侌轨というものは、人生の、あるいはれんかれ

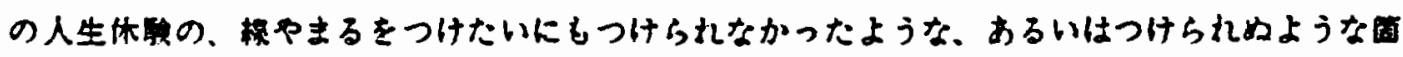

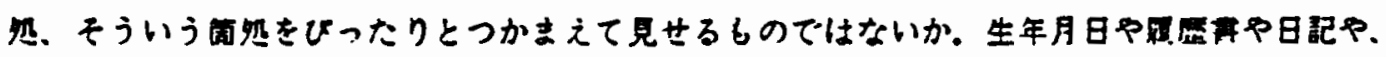

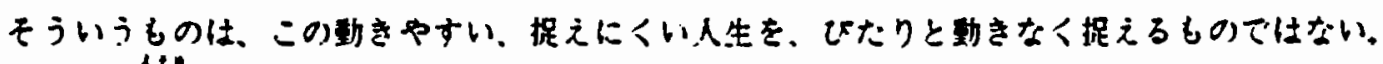

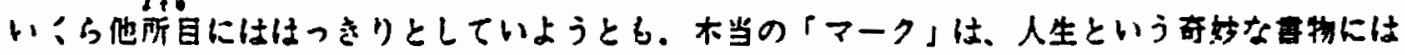
芸㑝制造による以外にはつけることができめのである。

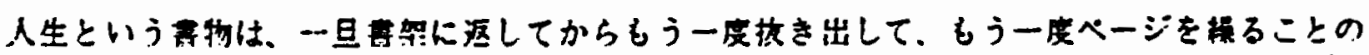

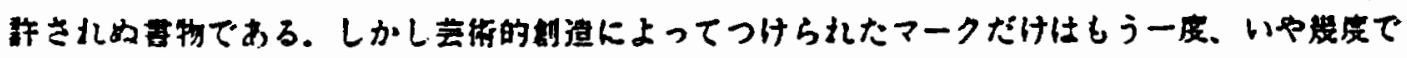

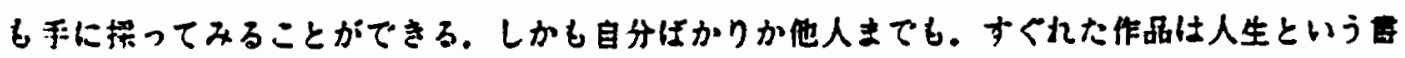

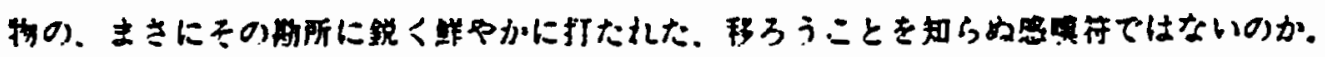




\section{少数民族の交流}

米国から、スーインティアンの少年少女五人がやって来て、アイヌの人々を訪机た。

北海道・平取町の二風谷（にふたた）である。折からアイヌ民族の层赫行事、チブサ ンケ（舟下ろし祭り）があった。かつて密林（ニブタイ）で、カッラの丸㮽（チプ） を初めて川に下ろす時に、航に魂を入れ、安全と瞣漁を析る。インティンの子たちも 分乘、砗式に参加した。

その前夜祭で波らが喜んだのか、、アイのの踊りだった。「私たちの頻りにそっくり」 とノーマ短。もちろん、いっしょに踊った。自分たちも、と用意してきテープで音策 を流し、インティアンの踊り。この輪にアイヌの人たちも加わった。

スー族はサウスダコタ州に住む。タコタは「同盟」を意味するスーのことばた。五 人の高校生の一人はストライクスエネミー（敵をやっつける）という勇ましい名字を持つ ている。みなアルバイトで資金をため、日本に来た。「ビンゴ・ゲームの遊揚で井 当を芫って稼ぎました」(マーク君)。

計画したのは両国のYMC A た。引率役のYMCA主事コール氏の感想は「アイヌの 人々が自らの文化、価值躀、云梳をしっかり守り、云承するさまに接して、高校生たちに はすばらしい矣强になった」。エクアドル、インドなど、他の国の先住民族とも交流し ているか、アイヌの人々との接蜰や資料能見学などははじめてだった。

米国の若いインティアンたちん明るい捋来展望をもてないものか多いといわれる。 差别に苦しみ、希望を失いがちだという。圈人として、民族として、固有の文化を层え ていきたい。その点で、コール氏によればアイヌの人タは一行を「勇気すけてくれ た」。

これとは別に、ホビ薿のインテ、アンが「ホビ独立国」の旅券で来日している。少数民

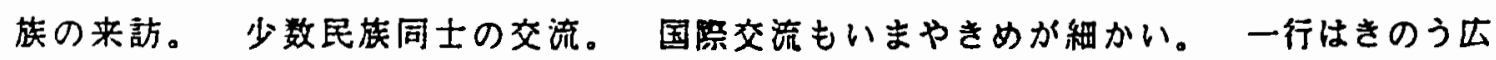
島にむかった。 


\section{宇宙混雑時代}

山や海で、空をながめる。罢にたのしい。大きなカンバス。刻々かわる票の表 情。色のうつろいに、時のたつのを忘れる。

夜空もすばらしい，星くず，流れ星。薄暮、明け方などには、人工衛星が見える

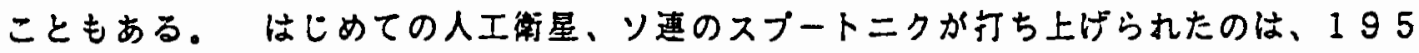
7 年十月だった。早朝五時前に、札幌の上空を衙星が横切るのを発見した時は、いささ か興した。北の空を西から東へ。定規で引いたように、着実に、静かに飛んでいっ た。

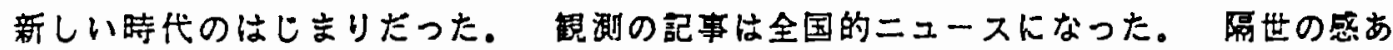
リ。もまや事情がちがう。 あまりにも衙星や打ち上げ物体がたくさんあって、大げさ にいうなら、いまや宇宙混雓時代らしい，轨道をるわっている人工物体の数は七千以 上、と欧州宇宙機関報告している。

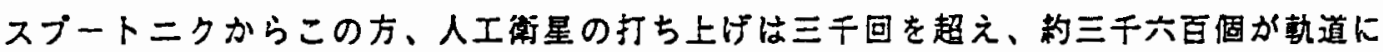
柰った。 さらに他の打ち上げ物体や、それらの破片もある。活動中のものは一部た が、とにかくたくさんの物体か宇宙空間を秉んでいる。梨速十キ口などという速度で破 片が䘖突すると、衛星や宇宙船が岛つき、こわれるおそれもある。

赤道上筀、高度三万六千キロの、いかゆる静止轨道も混み合ってきた。機能かとまっ た物体、つまり宇宙粗大ゴミを、どう処理するかはむずかしい骤題だ。もっと火急の問 題は、この秋にも落下するといかれるソ連の海样傎察衙星コスモス1900号である。 偵察用レーダーの電源として、小型原子妒を積んでいる。

十年前に、コスモス954号がカナダ北部に落ちたとき、雪の原野に故射能がき散ら された。大気圈に突入して然えつきてしまう場合も、污染の問題は牫る。米国の原子 炬䘖星も二十年あまり前に落ちた。今回、落ちる時刻は二、三日前、正確な落下点法二 時間前にはしめてかかる、とか。

星の世界も牧歌的といってはいられない。 


\section{イラン旅客機撃墜事件}

ニューヨークの䇾官は、道いかけている容者がホケットに手を入れかけたたけで、た

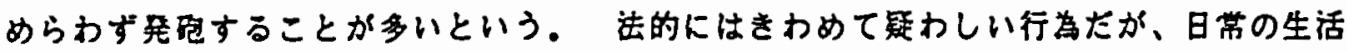
の中で、たれもが武器を持っている社会た。ややられないうちに、やる。 その考え方が 浸透しているらしい。

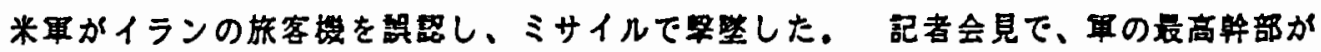
「司命官たちは、反洋する前に攻される手はない」と述べているのを就んで、ニューヨ

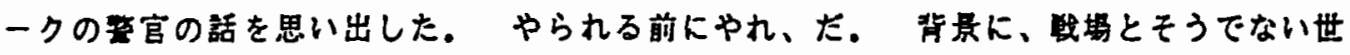
界が会わせ、という日常がある。

その結果、二百九十人のいのちが消えた。うち五十七人が十二藏以下の子供たったとの

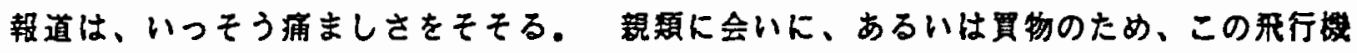

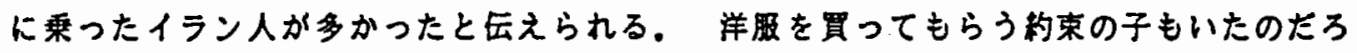
うか。

米倮は、正当な防䚘行助たと強謂している。しかし、これまで発表された并明内容

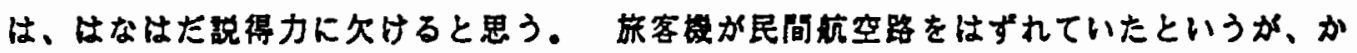
リにそうたとしても、何十キロもはずれていたとは考えにくい，管告したのに店答がな

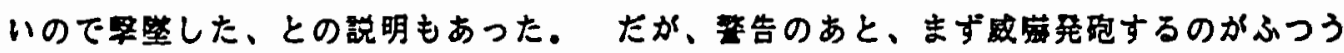
ではないか。

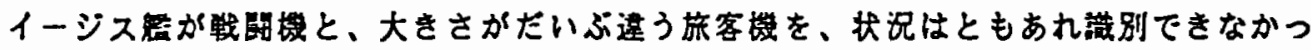
た点も、重要な問題た。米軍高官は「イージスシステムは万能ではない」と語っている

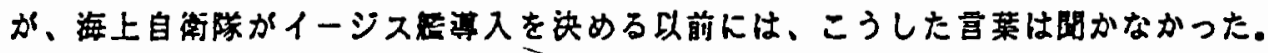

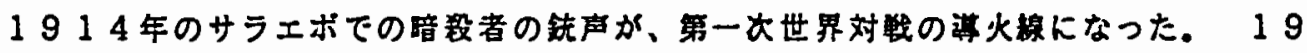

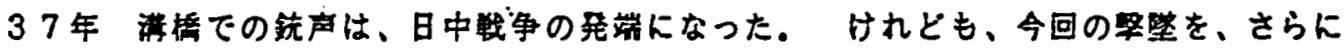

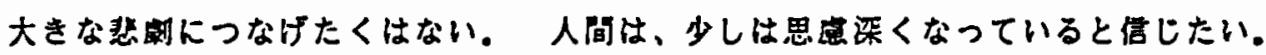




\section{渡り鳥}

いつのまにか、東京のまちからッパメの安が見えなくなった。冬をひかえ、泥の虾に もぐって越冬にはいったらしい、と考えたのはむかしの話。

もち万ん、南へ向けて我ひたちはしめあのた。一羽一羽か、私たちの前からをらめく 夏をすこしずつ通んていってしまう。北の方からいなくなり、頪戸内や九州あたりから も来月中には消すたろう。古の特急のスビードで、台湾、フ、リビン、さらに南方 へと㴖って中く。

カッコウ、ホトトギスなどの貝鳥にとっても族立ちのとを。沙に、平地に阵りて

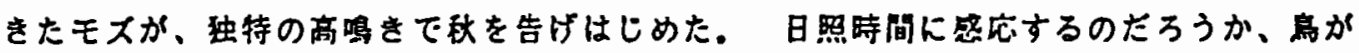

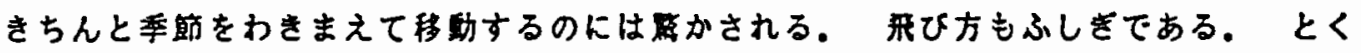
に、ひろい海原をわたるときなと、どうやって正しい方向を知るのたろう。

視賞、たとえば星席などをみることで判断するのか、それとも、においで感知するの

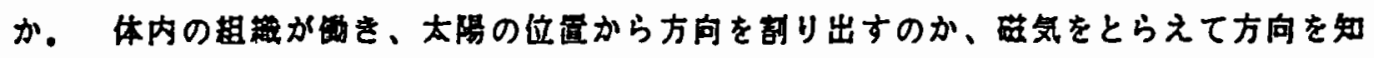

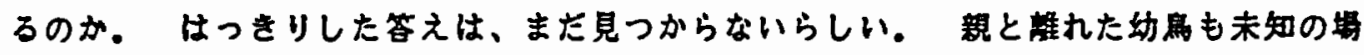
所に向かって茾心゙、というのたから感心する。

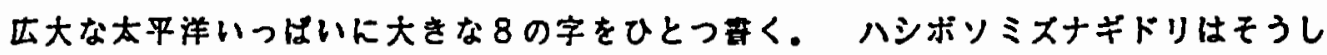
た轱路で和的する、と考えられていた。展近の研究によると、そうではないようた。

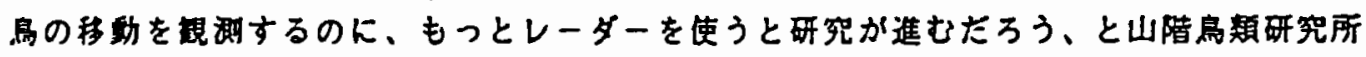
の吉井正さんはいう。

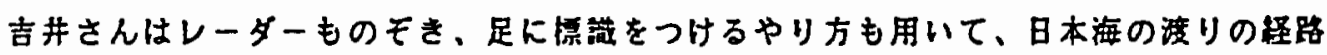

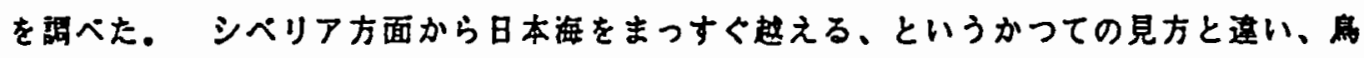

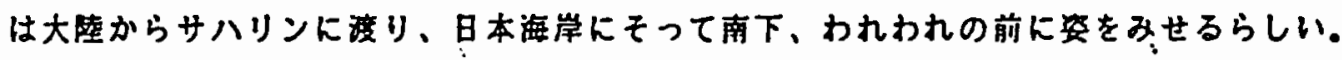

どんな道をたどって去るにせよ、来るにせよ、策美はたっぶり足りているたろうか。 ことしはとにかく不盾な夏たった。 


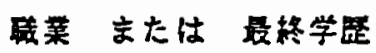

評価用紙：ルドルフの涙

1.作品としてのまとまり（内容・椪成） 1

實娽

2. 論琹の焦点・明碓さ

1

1

3.文体・嘉琹の一貫性

及ひ文間・段落间の接郓

4. 作品全体の印象

1

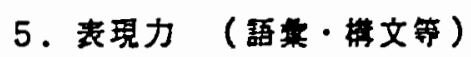

1

2

3

3

4

優秀

6. 搭合的部傮

E

2

3

4

5

2

3

4

5

2

3

$4 \quad 5$

2

3

$4^{\circ}: 5$

芸術と人生と

1. 作品としてのまとまり（内容・铔成） 1

武弱

2. 理の焦点・明確さ

1

D

C

B

A

3.文体・铨理の一鿓生 及ひ文间・段落间の妾繶

4. 作品全体の印象

1

1

1

2

3

4

5.表現力（語镡・草文等）

1

2

3

4

5

6 . 和合的部面

E

D

C

B

A

少数民族の交流

1.作品としてのまとまり（内容・構成）1

㒛

2. 琣理の焦点・明磼さ

1

2

3

但秀

2

2

3

4

5

3.文体・詥理の一貫柱

及ひ文间・段落间の接模

4. 作品全体の印象

1

2

3

4

5

5.表現力（語集・樌文等）

1

2

3

4

5

6. 糖合的評洒

1

2

3

4

5

E

D

C

4

5

C

B

A 
氏 名

\section{評価用紙：宇宙混雑時代}

1. 作品としてのまとまり(内容・㮖成) 1

具弱

2. 坮理の焦点・明確さ

1

2

2

3

质秀

3. 文体・韵理の一贯性

及ひ文间・殿落间の接繶

4. 作品全体の印象

1

2

3

5

5. 表現力（語重・楼文等）

1

2

3

5

6 . 給合的伻俩

1

2

3

5

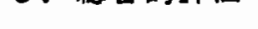

E

2

3

4

5

イラン旅客機擊墜事件

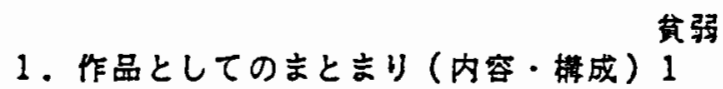

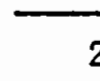

C

B

A

2. 踰理の焦点・明確さ

3. 文体・竵理の一贯性

及ひ文间・段落间の接辕

4. 作品全体の印象

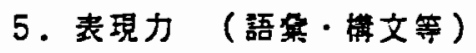

6. 站合的評洒
1

1

1

1

E

渡り鳥
2

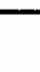

3

4

传忝

2

3

4

5

5

5

5

A
1.作品としてのまとまり（内容・權成） 1

\section{2. 新理の焦点・明確さ}

3. 文体・論理の一贯性

及び文间・段落简の接続

4. 作品全体の印象

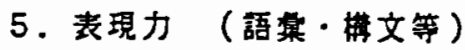

6. 的合的価

\section{1}

E

1

1
2

2

2

2

D

2

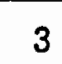

4

傮秀

5

5

5

C

B

A 


\section{APPENDIX B}

THE WRITING SAMPLES AND THE EVALUATION SHEET IN ENGLISH 


\section{RUDOLF'S TEARS (Sample A)}

Returning to his stable after being defeated in a big race, the favorite horse filled his eyes with "tears of vexation" and drooped his head. A female photographer, Toshie Imai, who continues to take photographs of thoroughbreds, successfully captured this rare scene with her camera and also published it in her photograph collection.

The favorite horse is Shinbori Rudolph, who is said to be the fastest in the history of Japanese horse racing. He shed tears when he was unexpectedly defeated by an ambush, Gallop Dina, in the fall Imperial Cup Race in 1985.

Race horses sometimes shed tears if dust or dirt blows into their eyes during races. However, Ms Imai still believes that the tears shed by Shinbori Rudolph at that occasion must have been tears of vexation for being defeated in the race.

When Ms Imai told me this story, I was very interested in it and asked several animal specialists whether horses, like humans, really shed tears of joy or vexation according to the movement of emotion. Although I did not receive clear answers, most of them said that horses are unlikely to shed tears of emotion.

Mitsuko Masui (the director of Inogashira Natural Cultural Garden), who is well-known for breeding of animals, has a negative opinion, saying, "I have not seen even higher animals like chimpanzees shedding tears of emotion. It will be the same in the case of horses. Besides, I don't think that horses understand whether they have won the race or not." Concerning the outcome of the race, a world-famous English zoologist, Desmond Morris, also stated, "Horses don't know they're winning races. They run only to make their jockeys happy."

In Europe, at the beginning of this century, a horse called Clever Hans caused a great sensation as "a horse who could do arithmetic." He surprised people by solving arithmetic problems written on a blackboard; for example, he tapped the floor five times with his front hoof when given the problem $2+3$. How could he do arithmetic? What really happened was that Hans tapped the floor, and when he got to the correct answer, the audience changed their facial expressions. He immediately sensed this change and stopped the tapping.

Even if they are not as capable as Hans, horses are sensitive to reading subtle changes in people's attitudes or in their faces. Therefore, they at once sense their jockeys' hope for a victory or their jockeys' expressions of joy when they win. This also supports Mr. Morris's argument that horses run in order to make their jockeys happy. When we think about it, it does not seem unnatural even if horses have "tears of emotion." 


\section{ART AND LIFE (Sample B)}

I read books. Sometimes, with a black, red, or blue pencil in my hand, I draw lines under the phrases which I think meaningful, under the names of people or places and the dates which I consider important. I circle them, group several lines with brackets, place exclamation points, and sometimes write, "That's right." -..-- In this way, I read books. Especially when I have finished reading a foreign book of 500 to 600 pages, I feel grand. Only those who have the same experience will understand this feeling. Satisfied, I turn over the pages of the book I have just finished. Red and black lines pass away kaleidoscopically. I become more satisfied and return the book to the bookcase.

And then, I think back with calm satisfaction what that book was really trying to say. However, I cannot recall clearly and immediately where the main parts and the important phrases and words are in the book. Being a little anxious, I take out the book which I returned to the bookcase once, and look for the main passages and the important phrases and words all over the book. Because they are such important and meaningful passages and words, they must be marked. Therefore, I check all the places which have some marks. The marked places are indeed all important in some respects. However, they do not necessarily represent the vague shape of the book which appeared in my mind after reading, in other words, the true nature of the book. This does not mean that the marked passages are not important. They are all important respectively. Nevertheless, none of them satisfactorily represents the essence of the book which has been, however, vaguely shaped in my mind. Strangely, even if I find the passages which seem to express the vision in my mind comparatively well, they do not have either underlinings, circles, or exclamation points. These pages have no traces of reading as if they had been carelessly skipped over. Unmarked passages still stand neatly in lines. I ask myself whether I have really read these passages. Without question, I must have read them. Sometimes very ironically, underlines are drawn till the line just before the passages in question. Then I lose the courage to draw a new line under those important passages. If I did such a thing, I would have to read the 600 page book again from the beginning. Anticipating the trouble of reading the book once more, and besides, as I have just finished reading it, I hesitate. I feel something inexplicable. Still feeling uneasy, I return the book once more to the bookcase. -...- I should surely have come across those important and meaningful sentences and phrases. Actually they have shaped the image of the book in my mind. Such places are, however, not only unmarked with a pencil, but sometimes cannot be found despite all my efforts.

This has lead me to entertain the following notions. Probably, ant captures and shows us the parts of life or our life experiences which we could not or cannot either underline or circle even if we wish to. Documents like dates of birth, resumes, or diaries do not capture exactly and motionlessly this rapidly changing and hardly catchable life. No matter how clearly they seem to capture it. Only artistic creation can place real "marks" in this peculiar book called life.

Unlike books, we are not allowed to pick up our lives and turn their pages again, once having returned them to the bookcase. However, we can take out and see the marks placed by artistic creation again, indeed, many times. Moreover, not only ourselves but also other people can see. Isn't an 
outstanding work of art an exclamation point which was placed sharply and vividly on the crucial points in the book called life and do not fade? 


\section{AMERICAN INDIANS IN JAPAN (Sample C)}

Five children from the Sioux Indian tribe in the United States recently arrived in Japan to visit the Ainu, the aboriginal race living in Hokkaido.

The meeting took place in Nibutani in Hiratori Town, Hokkaido. The visit from the Sioux children coincided with the "chipusanke" (boat christening festival), a traditional Ainu event. Nibutani used to be a thick forest ("niputai") with many katsura trees. When a katsura dugout canoe ("chipu") is first placed in the river, it is given a soul, and prayers are offered for safety and big fish catches. The Indian children rode in the canoes and participated in the ceremony.

For the Sioux children, the highlight of the occasion was the Ainu dance held on the eve of the festival. "It's exactly like our dancing," Norma Jiron said. Jiron and the other visiting children danced together with the Ainu. As well, they performed a Sioux dance accompanied by a prerecorded tape. The Ainu people joined the dance.

The Sioux tribe lives in South Dakota. "Dakota" is a Sioux word meaning alliance or league. One of the five Sioux high school students, Bernard, has a stirring surname: "Strikesenemy. The children worked at odd jobs to earn the money to come to Japan. "I earned money by selling box lunches at a bingo hall," Mark Lebeau said.

The visit was planned jointly by a YMCA office in Yamanashi Prefecture and the Sioux Indian YMCA in South Dakota. In the words of Dwight Call, a YMCA general secretary who escorted the children to Japan, "It was very valuable for the children to come into contact with the Ainu, a race which is firmly protecting and handing down its culture, sense of values and tradition." The Sioux YMCA has also organized exchanges with aboriginal minorities in other countries, such as Ecuador and India, but this is the first time that the Ainu have been included.

It is said that among young Indians in the United States, there are many without a bright future to look forward to. They suffer from discrimination and lose hope. As individuals and as a race, they want to hand down their special culture and, according to Call, the Ainu "gave courage" to the Sioux children who must accomplish this goal.

Another exchange is currently taking place as a group of Hopi Indians are visiting Japan on Hopi tribal nation passports. While witnessing visits from minority races and exchanges between minority races, we realize that international exchange has become a multifaceted thing.

The Hopi group left for Hiroshima on August 23. 


\section{TAMPERING WITH SPACE (Sample D)}

It is very enjoyable to gaze at the sky from the top of a mountain or from the sea. Viewed from these places, the sky is a huge canvas. The clouds change from moment to moment. As you watch the colors change, you lose your awareness of the passage of time.

The night sky is also wonderful. Stars sprinkling over the darkness. Shooting stars. Sometimes at dusk or early dawn, you can see man-made satellites. It was in October 1957 that the first man-made satellite, the Soviet Union's Sputnik, was launched. I remember being very excited when I stood in Sapporo at 5 a.m. and watched the satellite cutting across the sky. In the northern sky, the satellite flew silently and accurately from west to east as if on a line drawn with a ruler.

It was the start of a new age. Articles describing sightings of the satellite were national news. But the situation is now completely changed. Now, so many satellites and other objects have been launched into space that we are in an age of space congestion. The European Space Agency reports that there are now more than 7,000 man-made objects in orbit.

Since the launch of the Sputnik, there have been over 3,000 satellite launchings, and about 3,600 have gone into orbit. And there are many other man-made objects in space, including pieces which have broken off the orbiting satellites. Only some of these pieces are active but, at any rate, there are many objects flying around in space. These pieces fly at a speed of around 10 kilometers per second and there is the danger that they might hit satellites and spaceship, thus damaging or destroying them.

The so-called stationary orbit path which lies 36,000 kilometers above the Equator has become especially crowded. Scientists are now grappling with the problem of how to dispose of space objects which are no longer functioning (i.e. space garbage). An even more urgent problem is posed by the Cosmos 1900, a Soviet maritime reconnaissance satellite which will fall to Earth this autumn. It is carrying a small nuclear reactor -- the power source for its reconnaissance radar.

When Cosmos 954 fell in the northern part of Canada 10 years ago, radioactivity was scattered over the snow-covered wilderness. Even in cases where satellites crash into the atmosphere and burn out, the problem of contamination remains. As well, an American satellite with a nuclear reactor crashed to Earth over 20 years ago. As for the Cosmos 1900, it is said that the crash time will be known two or three days in advance and an accurate crash site determination will be made with two hours to spare.

The world of stars can no longer be called natural. 


\section{IRAN AIRBUS DOWNED (Sample E)}

It is said that policemen in New York would shoot without hesitation if the suspect they are chasing puts his hand in his pocket. Legally it is a very questionable action, but in a society in which everyone seems to own a gun, you shoot before you get shot. This thinking apparently has filtered into the minds of the people.

A U.S. Navy cruiser mistook an Iranian airliner for a fighter plane and shot it down with a missile. Reading that the top military leader said at a press conference that there was no need for a commander to be attacked before counterattacking, I recalled the policemen of New York. It's this "shoot before you get shot" mentality. The fact that the battlefront and the ordinary life are back to back in the daily life forms the background of this mentality.

As a result, the lives of 290 people were lost. The report that 57 were children 12 years old and under makes the incident all the more heartbreaking. It is reported that many Iranians boarded the airliner to meet relatives or to go shopping. Were there children who had been promised new clothes?

The United States is arguing that it is "a proper defensive action. "But it seems that the contents of the explanations announced so far are severely lacking in persuasive power. The United States says the airliner was off the regular commercial course, but it is difficult to believe it was off course by 20 30 kilometers. There was also the explanation that the airliner was warned but did not answer so it was shot down. Isn't it normal to fire a waming shot after issuing a warning?

Another major problem is the fact that the Aegis warship was unable to distinguish between a fighter plane and a much larger airliner whatever the circumstances. A high U.S. military official said that Aegis system is not omnipotent, but such words were not heard prior to the Japanese Maritime Self-Defense Force deciding to purchase Aegis warships.

The gunshot of an assassin in Sarajevo, Yugoslavia, in 1914 became the fuse which lit off World War I. The sounds of the shots fired at the Marco Polo Bridge in 1937 were the beginning of the Sino-Japanese war. But this latest shooting down of an airliner should not be tied to an even bigger tragedy. We would like to believe that human beings have become somewhat more prudent and sensible. 


\section{THE MYSTERIES OF BIRD MIGRATION (Sample F)}

Without anybody noticing, the swallows have disappeared from the streets of Tokyo. In ancient times, it was believed that, as winter approached, the swallows hibernated by burying themselves in the earth.

Now, in modern times, we know that the swallows fly south. Little by little, from north to south the swallows are taking summer away from us. Sometime in October, they will leave the Seto Inland Sea and Kyushu. At the speed of super-express trains, they will fly to Taiwan, the Philippines, and even further south.

Now is the time of departure for such summer birds as the common cuckoo and the Japanese cuckoo. The shrike, now here in the plains to replace the cuckoos, has started to herald the arrival of autumn with its distinctive high-pitched cry. I am amazed by the fact that birds migrate in precise harmony with the seasons. I wonder if they are guided by the number of hours of daylight. I also marvel at the way they fly. I wonder how they always know the correct direction, especially when they fly over wide seas.

Do they orient themselves visually by looking at star constellations? Or do they use their sense of smell? Does something within their bodies allow them to deduce direction by looking at the position of the sun? Or do they determine direction through an ability to measure magnetism? Apparently, this secret has still not been uncovered. Even baby birds, when separated from their parents, fly in the correct direction, toward places they have never seen. This is impressive.

Over the huge Pacific Ocean, birds' migration paths form a huge figure 8. It has long been believed that the slender-built shearwater takes this route to get to Japan. Recent research, however, shows that this opinion may not be correct. Tadashi Yoshii of the Yamashina Institute for Ornithology says that if radar were used more frequently as a way to observe bird migration, much research progress would be made.

Yoshii has attached bands to birds and used radar to check migration routes over the Japan Sea. Instead of flying straight over the Japan Sea from Siberia -- the previously assumed course -- birds apparently fly from the continent to Sakhalin, then southward along the Japanese coast, before appearing here.

No matter which routes they use to come to Japan and then to fly away again, I wonder if they have had enough food. Because this past summer was so irregular, it must have been difficult for the birds to find foods. 


\section{IRAN AIRBUS DOWNED (Sample E2)}

A U.S. Navy cruiser mistook an Iranian airliner for a fighter plane and shot it down with a missile. As a result, the lives of 290 people were lost. The report that 57 were children 12 years old and under makes the incident all the more heartbreaking. It is reported that many Iranians boarded the airliner to meet relatives or to go shopping. Maybe there were children who had been promised new clothes.

Reading that the top military leader said at a press conference that there was no need for a commander to be attacked before counterattacking, I recalled policemen of New York. It is said that policemen in New York would shoot without hesitation if the suspect they are chasing puts his hand in his pocket. Legally this is a very questionable action, but in a society in which everyone seems to own a gun, you shoot before you get shot. This thinking apparently has filtered into the minds of the people. It's this "shoot before you get shot" mentality. The fact that the battlefront and the the ordinary life are back to back in the daily life forms the background of this mentality.

The United States is arguing that shooting down of the Iranian airliner is "a proper defensive action." However, it seems that the contents of the explanations announced so far are severely lacking in persuasive power. The United States says the airliner was off the regular commercial course, but it is difficult to believe it was off course by 20-30 kilometers. There was also the explanation that the airliner was warned but did not answer so it was shot down. Isn't it normal to fire a warning shot after issuing a warning?

Another major problem is the fact that the Aegis warship was unable to distinguish between a fighter plane and a much larger airliner whatever the circumstances. A high U.S. military official said that the Aegis system is not omnipotent, but such words were not heard prior to the Japanese Maritime Self-Defense Force deciding to purchase Aegis warships.

The gunshot of an assassin in Sarajevo, Yugoslavia, in 1914 became the fuse which lit off World War I. The sounds of the shots fired at the Marco Polo Bridge in 1937 were the beginning of the Sino-Japanese war. But this latest shooting down of an airliner should not be tied to an even bigger tragedy. We would like to believe that human beings have become somewhat more prudent and sensible. 
Evaluation Sheet for "Rudolf's Tears"

Student / Instructor

Evaluation of the writing
1. Unity:
singleness of purpose 1
poor
$2 \quad 3 \quad 4 \quad 5$

2. Focus

staying on the topic

without wandering

3. Coherence

"sticking together" of 1

23

4

5

major parts of writing,

use of transitions
4. Holistic evaluation
1
23
4
5

Questionnaire

1. How different do you think this composition is from English composition?

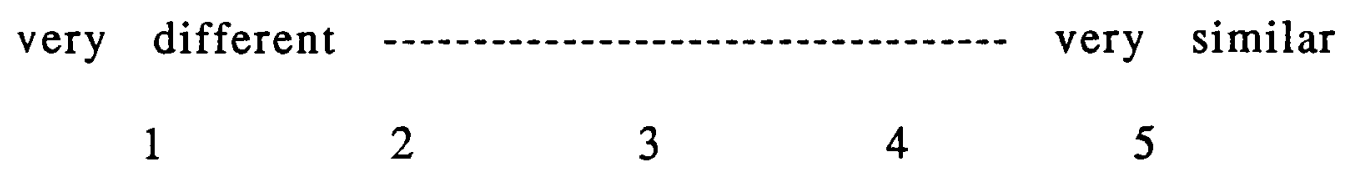

2. In what ways do you think this composition is different from English composition?

(1). Intraparagraph Level

(2). Interparagraph Level 


\section{APPENDIX C}

THE WRITING SAMPLES AND THE RESULTS OF THE PILOT STUDY 


\section{VANISHING 'TOKI'}

There is a fierce debate about what steps can be taken to save the "toki" (Japanese crested ibis), an internationally protected bird which is on the verge of extinction. Some people argue that all the wild "toki" should be captured and allowed breed in captivity. Other people say if artificial breeding fails, it will lead to the extinction of the birds and that the best thing to do is to leave them quietly alone.

As we were thinking about the fate of the "toki," we recalled the story of Konton in "Chang-tsu." The king of the southern seas and the king of the northern seas visited Konton, the king of the center. Konton happily welcomed and entertained them. To repay Konton's goodwill, the two created seven holes -- in Konton, who didn't have a single hole. Konton died after the seventh hole was made. The king of the northern waters and the king of the southern waters made the holes with good intentions, but with frightening callousness. There was indiscriminate hunting with guns after the Meiji Era. And the indiscriminate cutting down of forests and the use of agricultural chemicals have robbed the "toki" of their habitats.

Many years ago it was possible to see "toki" in the suburbs of Tokyo. The "toki" was so well known to the Japanese people that the word "toki-iro" ("toki"-color, pink) was born. The scientific name for the "toki" is Nipponia nippon. Even if the whole world is searched, it seems that only six or eight wild "toki" will be found in Sado in Japan and only one on the Korean Peninsula. If the seventh hole is made, the "toki" will definitely become extinct.

Even if the "toki" are captured, there is no guarantee that the increased numbers of "toki" can be successfully returned to nature in Sado. On the other hand, there is also no guarantee that their number will increase naturally if they are left alone. What is needed most now is the filling in of the holes which were made one after the other. In other words, it is necessary to create an environment in which the "toki" can live.

The danger of extinction was pointed out 20 years ago, but there have been no strong and systematic measures taken to protect the "toki." We feel that no matter what is done, it is already too late. 


\section{VANISHING TOKI 2}

There is a fierce debate about what steps can be taken to save the "toki" (Japanese crested ibis), an internationally protected bird which is on the verge of extinction. Some people argue that all the wild "toki" should be captured and allowed to breed in captivity. Other people say if artificial breeding fails, it will lead to the extinction of the birds and that the best thing to do is to leave them quietly alone.

Many years ago it was possible to see "toki" in the suburbs of Tokyo. The "toki" was so well known to the Japanese people that the word "toki-iro" ("toki"-color, pink) was born. The scientific name for the "toki" is Nipponia nippon. However, there was indiscriminate hunting with guns after the Meiji Era. And the indiscriminate cutting down of forests and the use of agricultural chemicals have robbed the "toki" of their habitats. Even if the whole world is searched, it seems that only six or eight wild "toki" will be found today in Sado in Japan and only one on the Korean Peninsula.

As we were thinking about the fate of the "toki," we recalled the story of Konton in "Chang-tsu." the king of the southern seas and the king of the northern seas visited Konton, the king of the center. Konton happily welcomed and entertained them. To repay Konton's goodwill, the two created seven holes -- for ears, eyes, mouth, etc. -in Konton, who didn't have a single hole. Konton died after the seventh hole was made. The king of the northern waters and the king of southern waters made the holes with good intentions, but with frightening callousness. Similarly, if the seventh hole is made, the "toki" will definitely become extinct. What is needed most now is the filling in of the holes which were made one after the other. In other words, it is necessary to create an environment in which the "toki" can live.

The danger of extinction was pointed out 20 years ago, but there have been no strong and systematic measures taken to protect the "toki." Even if the "toki" are captured, there is no guarantee that the increased numbers of "toki" can be successfully returned to nature in Sado. On the other hand, there is also no guarantee that their number will increase naturally if they are left alone. We feel that no matter what is done, it is already too late. 
RESULTS OF THE PILOT STUDY

\section{MEANS OF THE EVALUATION CATEGORIES}

\begin{tabular}{|l|c|c|}
\hline & Vanishing "Toki" & Vanishing "Toki" 2 \\
\hline Unity & 2.4 & 3.3 \\
\hline Focus & 2.4 & 3.6 \\
\hline Coherence & 2.4 & 3.2 \\
\hline Holistic Impression & 2.7 & 3.3 \\
\hline
\end{tabular}

